\title{
Effects of Historical Coal Mining and Drainage from Abandoned Mines on Streamflow and Water Quality in Bear Creek, Dauphin County, Pennsylvania-March 1999_ December 2002
}

By Jeffrey J. Chaplin

In cooperation with the Dauphin County Conservation District

Scientific Investigations Report 2005-5042 


\title{
U.S. Department of the Interior Gale A. Norton, Secretary
}

\author{
U.S. Geological Survey \\ Charles G. Groat, Director
}

\section{U.S. Geological Survey, Reston, Virginia: 2005}

\author{
For sale by U.S. Geological Survey, Information Services \\ Box 25286, Denver Federal Center \\ Denver, C0 80225 \\ For more information about the USGS and its products: \\ Telephone: 1-888-ASK-USGS \\ World Wide Web: http://www.usgs.gov/
}

Any use of trade, product, or firm names in this publication is for descriptive purposes only and does not imply endorsement by the U.S. Government.

Although this report is in the public domain, permission must be secured from the individual copyright owners to reproduce any copyrighted materials contained within this report.

Suggested citation:

Chaplin, J.J., 2005, Effects of historical coal mining and drainage from abandoned mines on streamflow and water quality in Bear Creek, Dauphin County, Pennsylvania-March 1999-December 2002: U.S. Geological Survey Scientific Investigations Report 2005-5042, 45 p. 


\section{Contents}

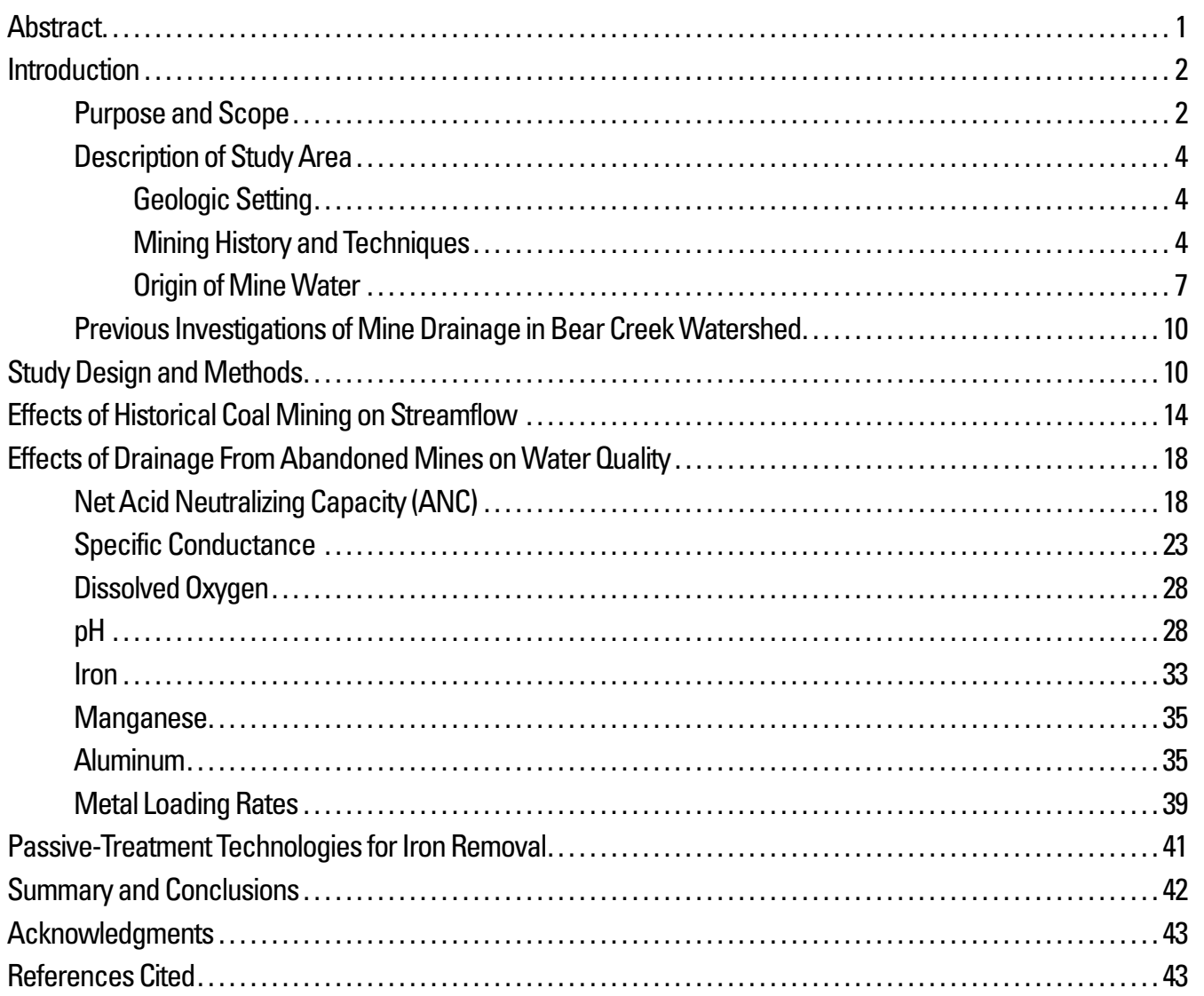




\section{Figures}

1. Map showing locations, sampling sites, historical coal-mining features, geologic cross sections, and proposed treatment within and proximate to Bear Creek watershed,

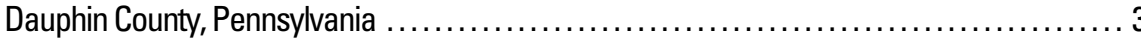

2. Geologic cross section M-M' showing anthracite coal-bearing strata in Bear Creek watershed, Dauphin County, Pennsylvania 5

3. Geologic cross section $0-Q^{\prime}$ s showing anthracite coal-bearing strata in Bear Creek watershed, Dauphin County, Pennsylvania 6

4-6. Photographs showing:

4. Mine drainage discharging from the Lykens Water-Level Tunnel (LWLT) in Bear Creek watershed, Dauphin County, Pennsylvania

5. Mine drainage discharging from the Lykens Drift (LD) discharge in Bear Creek watershed, Dauphin County, Pennsylvania

6. Mine drainage from several seeps adjacent to the Lykens Drift discharge in Bear Creek watershed, Dauphin County, Pennsylvania 9

7. Streamflow hydrograph for Bear Creek downstream of mine inputs (BC-DMD) superimposed on instantaneous streamflow measurements upstream of mine inputs (BC-UMD), and precipitation measured approximately 8.5 miles southwest of Bear Creek at DeHart Reservoir Dam 14

8. Pie chart showing percent contribution of base flow (A) and stormflow (B) to Bear Creek downstream of mine drainage (BC-DMD) computed as the mean ratio of instantaneous flow at sites Bear Creek upstream of mine drainage (BC-UMD), Lykens Water-Level Tunnel (LWLT), and Lykens Drift (LD) to instantaneous flow at site BC-DMD

9-20. Graphs showing:

9. Ranges of net acid neutralizing capacity measured at seven sites in the Bear Creek study area, Dauphin County, Pennsylvania, from March 1999 to December 2002.

10. Relation of net acid neutralizing capacity to flow at seven sites in the Bear Creek study area, Dauphin County, Pennsylvania, from March 1999 to December 2002 . .... 24

11. Ranges of specific conductance measured at seven sites in the Bear Creek study area, Dauphin County, Pennsylvania, from March 1999 to December 2002 . . . . . 26

12. Relation of specific conductance to flow at seven sites in the Bear Creek study area, Dauphin County, Pennsylvania, from March 1999 to December 2002

13. Ranges of dissolved oxygen measured at seven sites in the Bear Creek study area, Dauphin County, Pennsylvania, from March 1999 to December 2002 . ...

14. Relation of dissolved oxygen to flow at seven sites in the Bear Creek study area, Dauphin County, Pennsylvania, from March 1999 to December 2002

15. Ranges of $\mathrm{pH}$ measured at seven sites in the Bear Creek study area, Dauphin County, Pennsylvania, from March 1999 to December 2002

16. Relation of $\mathrm{pH}$ to flow at seven sites in the Bear Creek study area, Dauphin County, Pennsylvania, from March 1999 to December 2002

17. Ranges of dissolved and total iron measured at seven sites in the Bear Creek study area, Dauphin County, Pennsylvania, from March 1999 to December 2002 . .... 34

18. Relation of dissolved and total iron to flow at seven sites in the Bear Creek study area, Dauphin County Pennsylvania, from March 1999 to December 2002. 36

19. Ranges of dissolved and total manganese measured at seven sites in the Bear Creek study area, Dauphin County, Pennsylvania, from March 1999 to December 2002. 


\section{Figures-Continued}

9-20. Graphs showing - Continued:

20. Relation of dissolved and total manganese to flow at seven sites in the Bear

Creek study area, Dauphin County, Pennsylvania, from March 1999 to

December 2002.

21. Sketch showing mean loading rates of total iron (FE) and manganese (MN) in the

Bear Creek study area, Dauphin County, Pennsylvania

22. Flow chart of passive-treatment alternatives adapted from Hedin and others (1994)

and Skousen and others (2000) 41

\section{Tables}

1. Water-quality standards and Total Maximum Daily Loads for iron and manganese at the mouth of Bear Creek, Dauphin County, Pennsylvania..

2. Sampling sites in the Bear Creek and Wiconisco Creek watersheds, Dauphin County, Pennsylvania.

3. Comparison of selected constituents in duplicate samples analyzed separately by the Pennsylvania Department of Environmental Protection Laboratory and the U.S. Geological Survey National Water-Quality Laboratory.

4. Summary of instantaneous flow data collected at nine sites on Bear Creek and two sites on Wiconisco Creek, Dauphin County, Pennsylvania, from March 1999 to December 2002........ 16

5. Summary statistics for water-quality data collected at nine sites on Bear Creek and two sites on Wiconisco Creek, Dauphin County, Pennsylvania, from March 1999 to December 2002........ 20

6. Results of statistical analyses performed on four paired sites in the Bear Creek study area, Dauphin County, Pennsylvania. ...

7. Computed mean loads of dissolved iron and total manganese compared to Total Maximum Daily Loads at selected sites in the Bear Creek watershed, Dauphin County, Pennsylvania. 


\section{Conversion Factors, Abbreviated Water-Quality Units, and Datum}

\begin{tabular}{|c|c|c|}
\hline Multiply & By & To obtain \\
\hline \multicolumn{3}{|c|}{ Length } \\
\hline inch (in.) & 2.54 & centimeter $(\mathrm{cm})$ \\
\hline inch (in.) & 25.4 & millimeter (mm) \\
\hline foot $(\mathrm{ft})$ & 0.3048 & meter $(\mathrm{m})$ \\
\hline mile (mi) & 1.609 & kilometer (km) \\
\hline \multicolumn{3}{|c|}{ Area } \\
\hline acre & 4,047 & square meter $\left(\mathrm{m}^{2}\right)$ \\
\hline acre & 0.4047 & hectare (ha) \\
\hline square mile $\left(\mathrm{mi}^{2}\right)$ & 2.590 & square kilometer $\left(\mathrm{km}^{2}\right)$ \\
\hline \multicolumn{3}{|c|}{ Volume } \\
\hline gallon (gal) & 3.785 & liter $(\mathrm{L})$ \\
\hline gallon (gal) & 0.003785 & cubic meter $\left(\mathrm{m}^{3}\right)$ \\
\hline cubic foot $\left(\mathrm{ft}^{3}\right)$ & 0.02832 & cubic meter $\left(\mathrm{m}^{3}\right)$ \\
\hline billion gallons (bgal) & 0.13368 & cubic feet $\left(\mathrm{ft}^{3}\right)$ \\
\hline \multicolumn{3}{|c|}{ Flow rate } \\
\hline cubic foot per second $\left(\mathrm{ft}^{3} / \mathrm{s}\right)$ & 0.02832 & cubic meter per second $\left(\mathrm{m}^{3} / \mathrm{s}\right)$ \\
\hline cubic foot per second $\left(\mathrm{ft}^{3} / \mathrm{s}\right)$ & 448.9 & gallon per minute \\
\hline gallon per minute (gal/min) & 0.06309 & liter per second $(\mathrm{L} / \mathrm{s})$ \\
\hline \multicolumn{3}{|c|}{ Mass } \\
\hline pound, avoirdupois (lb) & 0.4536 & kilogram (kg) \\
\hline
\end{tabular}

Temperature in degrees Celsius $\left({ }^{\circ} \mathrm{C}\right)$ may be converted to degrees Fahrenheit $\left({ }^{\circ} \mathrm{F}\right)$ as follows:

$$
{ }^{\circ} \mathrm{F}=\left(1.8 \times{ }^{\circ} \mathrm{C}\right)+32
$$

Vertical coordinate information is referenced to the National Geodetic Vertical Datum of 1929 (NGVD 29).

Horizontal coordinate information is referenced to the North American Datum of 1927 (NAD 27) and the North American Datum of 1983 (NAD 83).

Altitude, as used in this report, refers to distance above the vertical datum.

Specific conductance is given in microsiemens per centimeter at 25 degrees Celsius $1 \mu \mathrm{S} / \mathrm{cm}$ at $\left.25^{\circ} \mathrm{C}\right)$.

Concentrations of chemical constituents in water are given either in milligrams per liter ( $\mathrm{mg} / \mathrm{L}$ ) or micrograms per liter $(\mu \mathrm{g} / \mathrm{L})$.

Other abbreviations:

$\mathrm{mL}$, milliliter

$\mathrm{mV}$, millivolt

$\mu \mathrm{m}$, micrometer 


\title{
Effects of Historical Coal Mining and Drainage From Abandoned Mines on Streamflow and Water Quality in Bear Creek, Dauphin County, Pennsylvania- March 1999-December 2002
}

\author{
By Jeffrey J. Chaplin
}

\section{Abstract}

More than 100 years of anthracite coal mining has changed surface- and ground-water hydrology and contaminated streams draining the Southern Anthracite Coal Field in east-central Pennsylvania. Bear Creek drains the western prong of the Southern Anthracite Coal Field and is affected by metals in drainage from abandoned mines and streamwater losses. Total Maximum Daily Loads (TMDL) developed for dissolved iron of about $5 \mathrm{lb} / \mathrm{d}$ (pounds per day) commonly are exceeded in the reach downstream of mine discharges. Restoration of Bear Creek using aerobic ponds to passively remove iron in abandoned mine drainage is under consideration (2004) by the Dauphin County Conservation District. This report, prepared in cooperation with the Dauphin County Conservation District, evaluates chemical and hydrologic data collected in Bear Creek and its receiving waters prior to implementation of mine-drainage treatment. The data collected represent the type of baseline information needed for documentation of water-quality changes following passive treatment of mine drainage in Pennsylvania and in other similar hydrogeologic settings.

Seven surface-water sites on Bear Creek and two mine discharges were monitored for nearly three years to characterize the chemistry and hydrology of the following: (1) Bear Creek upstream of the mine discharges (BC-UMD), (2) water draining from the Lykens-Williamstown Mine Pool at the Lykens Water-Level Tunnel (LWLT) and Lykens Drift (LD) discharges, (3) Bear Creek after mixing with the mine discharges (BC-DMD), and (4) Bear Creek prior to mixing with Wiconisco Creek (BCM). Two sites on Wiconisco Creek, upstream and downstream of Bear Creek (WC-UBC and WC-DBC, respectively), were selected to evaluate changes in streamflow and water quality upon mixing with Bear Creek.

During periods of below-normal precipitation, streamwater loss was commonly 100 percent upstream of site BC-UMD (streamflow range $=0$ to $9.7 \mathrm{ft}^{3} / \mathrm{s}$ (cubic feet per second)) but no loss was detected downstream owing to sustained mine water drainage from the Lykens Water-Level Tunnel (range $=0.41$ to $3.7 \mathrm{ft}^{3} / \mathrm{s}$ ), Lykens Drift (range $=0.40$ to $6.1 \mathrm{ft}^{3} / \mathrm{s}$ ), and diffuse zones of seepage. Collectively, mine water inputs contributed about 84 percent of base flow and 53 percent of stormflow measured in the downstream reach.

An option under consideration by the Dauphin County Conservation District for treatment of the discharge from the LWLT requires the source of the discharge to be captured and rerouted downstream, bypassing approximately 1,000 feet of stream channel. Because streamwater loss upstream of the tunnel was commonly 100 percent, rerouting the discharge from the LWLT may extend the reach of Bear Creek that is subject to dryness.

Differences in the chemistry of water discharging from the LWLT compared to the LD suggest that the flow path through the Lykens-Williamstown Mine Pool to each mine discharge is unique. The LWLT is marginally alkaline (median net acid neutralizing capacity (ANC) $=9 \mathrm{mg} / \mathrm{L}$ (milligrams per liter) as $\mathrm{CaCO}_{3}$; median $\mathrm{pH}=5.9$ ), commonly becomes acidic (minimum net $\mathrm{ANC}=-74 \mathrm{mg} / \mathrm{L}$ as $\mathrm{CaCO}_{3}$ ) at low flow, and may benefit from alkaline amendments prior to passive treatment. Water discharging from the LD provides excess ANC (median net $\mathrm{ANC}=123 \mathrm{mg} / \mathrm{L}$ as $\mathrm{CaCO}_{3}$; median $\mathrm{pH}=6.5$ ) to the downstream reach and is nearly anoxic at its source (median dissolved oxygen $=0.5 \mathrm{mg} / \mathrm{L}$ ). Low dissolved oxygen water with relatively high ANC and metals concentrations discharging from the LD is characteristic of a deeper flow path and longer residence time within the mine pool than the more acidic, oxygenated water discharging from the LWLT.

TMDLs for iron have been developed for dissolved species only. Consequently, distinguishing between dissolved and suspended iron in Bear Creek is important for evaluating waterquality improvement through TMDL attainment. Median total iron concentration increased from $550 \mu \mathrm{g} / \mathrm{L}$ (micrograms per liter) at site BC-UMD (mean load of approximately $5 \mathrm{lb} / \mathrm{d}$ ) to $10,600 \mu \mathrm{g} / \mathrm{L}$ at site BCM (mean load of $540 \mathrm{lb} / \mathrm{d}$ ) but the TMDL was met at site BCM approximately 10 percent of the time because most of the iron at that site is suspended. Water draining from LWLT (median dissolved iron concentration = $5,170 \mu \mathrm{g} / \mathrm{L}$ ) and $\mathrm{LD}$ (median dissolved iron concentration = $18,300 \mu \mathrm{g} / \mathrm{L}$ ) undergoes oxidation and hydrolysis quickly. As a result, TMDL attainment at site BCM is a consequence of dissolved iron converting to suspended solids but is not indicative of improvement in water quality or benefits to aquatic life. To 


\section{Effects of Coal Mining and Drainage From Abandoned Mines on Streamflow and Water Quality, Bear Creek, 1999-2002}

properly interpret any improvement achieved through attainment of TMDLs developed for dissolved constituents, data for the corresponding suspended fraction are essential.

\section{Introduction}

Anthracite coal-bearing strata underlying the Bear Creek watershed in Dauphin County, Pa. (fig. 1), and adjacent basins in the Southern Anthracite Coal Field were mined extensively by surface stripping and underground methods beginning in the early 1800s (Wood and others, 1969). By the early 1900s, the most readily accessible coal had been mined, leaving behind only the deep seams that required expensive dewatering to extract. As the expense of coal extraction became prohibitive, mining in the Bear Creek watershed slowed, ceasing altogether in the 1930s (Wood and others, 1969). When mining ceased, many surface workings were left as open pits with some openings having connections to the deep underground mines. In the absence of dewatering pumps, surface runoff and ground-water seepage eventually flooded the underground mines, and a new hydrologic balance was established. Metal-laden water once pumped from the mines overflowed through tunnels and drift openings to Bear Creek.

As a consequence of receiving metal-laden drainage from the abandoned underground mines, Bear Creek commonly exceeds Total Maximum Daily Loads (TMDLs) developed for the watershed (Susquehanna River Basin Commission, 2001) and water-quality standards for its designated use as a coldwater fishery (Pennsylvania Department of Environmental Protection, 1998) (table 1). Iron loading is the largest contamination source limiting aquatic life in Bear Creek (Susquehanna River Basin Commission, 2001; Hedin Environmental, 1998; Stoe, 1998; Sanders and Thomas, Inc., 1973). Wiconisco Creek, which supports a viable trout population (Charles McGarrell,

Table 1. Water-quality standards and Total Maximum Daily Loads for iron and manganese at the mouth of Bear Creek, Dauphin County, Pennsylvania.

$[\mu \mathrm{g} / \mathrm{L}$, micrograms per liter; TMDL, Total Maximum Daily Load; --, not determined]

\begin{tabular}{lcc}
\hline \multicolumn{1}{c}{ Constituent } & $\begin{array}{c}\text { Water-quality } \\
\text { standard } \\
(\mu \mathbf{g} / \mathbf{L})^{\mathbf{1}}\end{array}$ & $\begin{array}{c}\text { TMDL } \\
\text { (pounds per day) }{ }^{\mathbf{2}}\end{array}$ \\
\hline Iron, total & 31,500 & -- \\
Iron, dissolved & 4300 & 6 \\
Manganese, total & 41,000 & 24 \\
\hline
\end{tabular}

${ }^{1}$ Pennsylvania Department of Environmental Protection, 1998.

${ }^{2}$ Total Maximum Daily Load at the mouth of Bear Creek (Susquehanna River Basin Commission, 2001).

${ }^{3}$ Daily mean concentration.

${ }^{4}$ Maximum concentration.
Pennsylvania Department of Environmental Protection, oral commun., 2000), also is compromised by metals loading in the reach downstream of Bear Creek.

Degradation of habitat and water quality from mine drainage entering Bear Creek has been recognized for decades (Sanders and Thomas, Inc.,1973; Stoe, 1998). Despite this, the problem currently (2004) is unchecked. Passive-treatment technologies developed in the mid-1990s reduce the costs of infrastructure, chemical amendments, and maintenance of conventional treatment (Hedin and others, 1994). Because of these developments, passive treatment is now under consideration by the Dauphin County Conservation District (DCCD) to reduce metals loading in Bear Creek and ultimately achieve compliance with established TMDLs.

DCCD, through the Pennsylvania Department of Environmental Protection (PaDEP) Growing Greener Program, and the U.S. Geological Survey (USGS) cooperated in an investigation from March 1999 to December 2002 to characterize the effects of historical coal mining and drainage from abandoned mines on streamflow and water quality in Bear Creek. Data collected during this investigation may be useful to water-resources managers and the private sector in design of passive-treatment systems. For example, see Hedin Environmental (2001) and Skelly and Loy, Inc. (2003) for passive-treatment alternatives to reduce iron loading in abandoned mine drainage before it mixes with Bear Creek. The data collected represent the type of baseline information needed for documentation of water-quality changes following passive treatment of mine drainage in Pennsylvania and in other similar hydrogeologic settings.

\section{Purpose and Scope}

This report provides hydrologic and chemical data for determining the effect of historical coal mining and drainage from abandoned mines on Bear Creek and its receiving waters. The evaluations in this report are based on hydrologic and chemical data collected between March 1999 and December 2002 by the USGS at seven stream sites on Bear Creek, two mine discharges entering Bear Creek, and two stream sites on Wiconisco Creek (one upstream and one downstream of Bear Creek). Hydrologic data consist of continuous (15-minute interval) flow determination at one site and instantaneous flow determinations at all other sites. Data for 18 chemical constituents are reported and those that are most useful for interpreting the effects of drainage from abandoned mines on Bear Creek are discussed in detail. These constituents include acid neutralizing capacity (ANC), specific conductance, dissolved oxygen, $\mathrm{pH}$, iron, manganese, and aluminum. This report also discusses passive-treatment technologies as options to remove iron from mine discharges. 


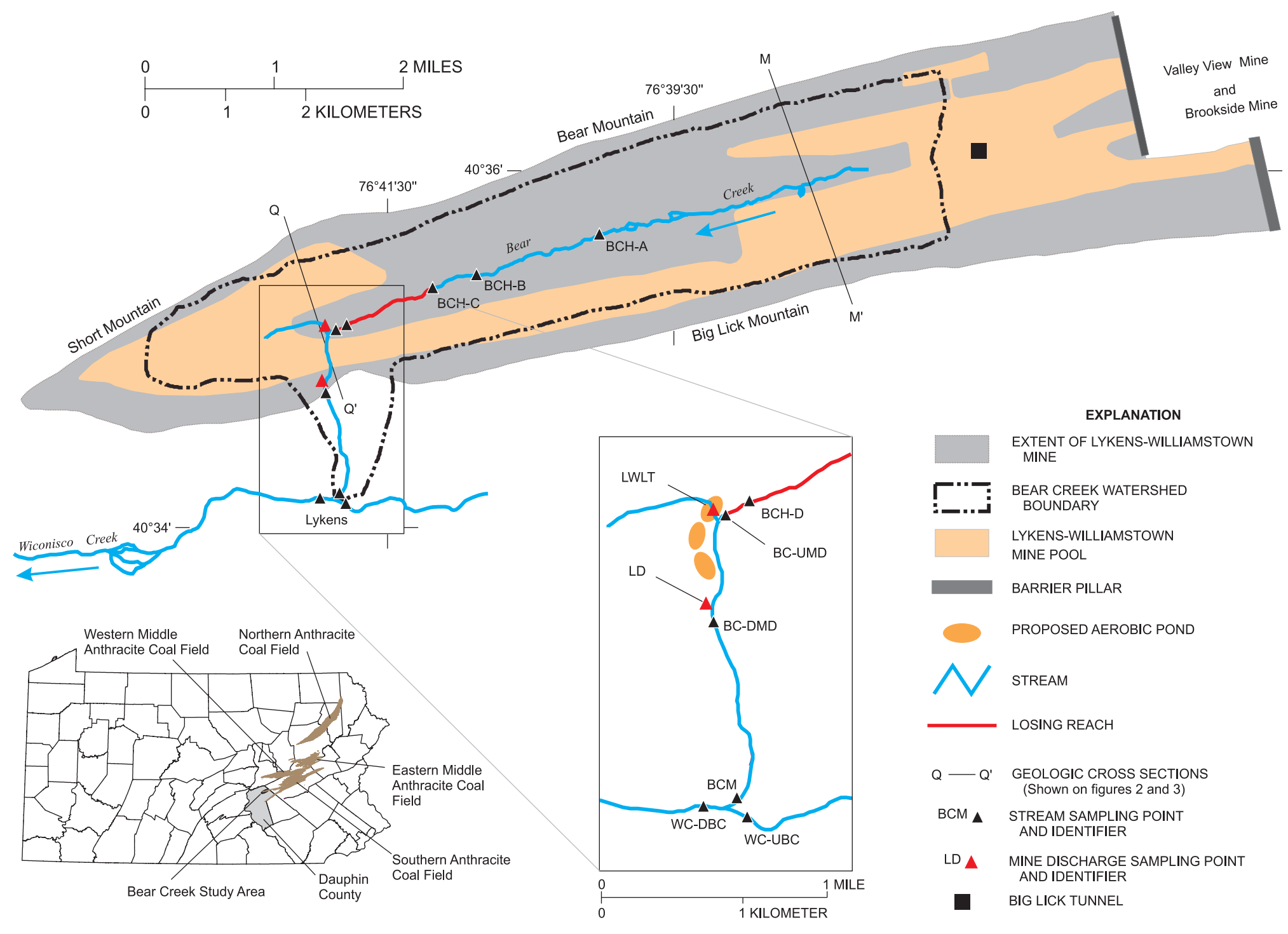

Figure 1. Locations, sampling sites, historical coal-mining features, geologic cross sections, and proposed treatment within and proximate to Bear Creek watershed, Dauphin County, Pennsylvania. Watershed boundaries and streams are digitized from Lykens, and Tower City, Pennsylvania, 7.5 minute, 1:24000, quadrangles. The Anthracite Coal Region is from Map 11 of the Pennsylvania Department of Conservation and Natural Resources (2000). Lykens-Williamstown Mine Pool boundaries and locations of barrier pillars are digitized from maps published by Ash and others (1949) and Ash and Kynor (1953). [WC-UBC, Wiconisco Creek upstream of Bear Creek; BCH-A, Bear Creek at headwaters - A; BCH-B, Bear Creek at headwaters - B; BCH-C, Bear Creek at headwaters - C; BCH-D, Bear Creek at headwaters - D; BC-UMD, Bear Creek upstream of mine drainage; LWLT, Lykens Water-Level Tunnel; LD, Lykens Drift; BC-DMD, Bear Creek downstream of mine drainage; BCM, Bear Creek at mouth; WC-DBC, Wiconisco Creek downstream of Bear Creek] 


\section{Effects of Coal Mining and Drainage From Abandoned Mines on Streamflow and Water Quality, Bear Creek, $1999-2002$}

\section{Description of Study Area}

Bear Creek drains the northwestern prong of the Southern Anthracite Coal Field in the Ridge and Valley Physiographic Province, south-central Pennsylvania (fig. 1). The headwaters of the creek flow from a wetland between Bear and Big Lick Mountains. The creek flows for a distance of $4.5 \mathrm{mi}$ where it discharges into Wiconisco Creek. The watershed is $4.7 \mathrm{mi}^{2}$, is mostly forested, and has been extensively mined on the surface and underground. Remnant mining features, including cropfalls and strip pits, are scattered throughout the watershed and convey a portion of surface runoff to underground mine workings (Skelly and Loy, Inc., 2003). The underground mine workings are collectively referred to as the Lykens-Williamstown Mine Pool (fig. 1), which discharges metal-laden drainage from Lykens Water-Level Tunnel (LWLT), Lykens Drift (LD), and diffuse zones of seepage to Bear Creek. A sewage-treatment plant, approximately $0.25 \mathrm{mi}$ above the mouth of Bear Creek, discharges treated effluent to Bear Creek. The plant is designed for a maximum influent flow of 125,000 gal per day; average monthly effluent limits for total suspended solids, dissolved oxygen, and $\mathrm{pH}$ are $45 \mathrm{mg} / \mathrm{L}$, greater than $5 \mathrm{mg} / \mathrm{L}$, and between 6 - 9 standard units, respectively (Pennsylvania Department of Environmental Protection, 1996).

\section{Geologic Setting}

Three principal formations, the Mauch Chunk, Pottsville, and Llewellyn, underlay the Bear Creek watershed and adjacent areas of the Southern Anthracite Coal Field (figs. 2 and 3). The Mauch Chunk Formation is of Late Mississippian and Early Pennsylvanian age and is successively overlain by the coalbearing Pottsville and Llewellyn Formations of Pennsylvanian age. The structural geology of these formations is complex (Wood and others, 1969; Wood and others, 1986). The Pottsville and Llewellyn Formations are characterized by tightly folded coal-bearing rock units that are interrupted by numerous faults (figs. 2 and 3). Some faults extend into the underlying Mauch Chunk Formation and may facilitate mixing of ground water between formations. Natural outcrops are rare (Wood and others, 1969), but rocks are exposed in many areas by strip pits and road cuts.

The Mauch Chunk Formation commonly ranges from 200 to $500 \mathrm{ft}$ thick in the Anthracite Coal Region but may be as much as $800 \mathrm{ft}$ thick in the vicinity of Bear Creek (Wood and others, 1986). The formation is divided into three informal members; the Upper, Middle, and Lower Members (Wood and others, 1986). Because differentiation of these members is complicated by lack of stratigraphic markers, faulting, and folding (Wood and others, 1986), they are not identified in figures 2 and 3. The lithology of the Mauch Chunk Formation is characterized by varying thickness and is composed of red and gray conglomerate, sandstone, siltstone, and shale (Wood and others, 1986). Cementing media include silica, limonite, hematite, uni- dentified clay minerals, sericite, and calcite (Wood and others, 1969).

The Pottsville Formation includes all strata between the underlying Mauch Chunk and overlying Llewellyn Formations and is divided into the Tumbling Run Member, the Schuylkill Member, and the Sharp Mountain Member (figs. 2 and 3) (Wood and others, 1956). The Tumbling Run Member is approximately $600 \mathrm{ft}$ thick and contains six anthracite coal beds. Three of these beds are known to have been mined (Lykens Valley Nos. 4, 5, and 6) (figs. 2 and 3). The Tumbling Run Member is overlain by the Schuylkill Member, which is approximately $700 \mathrm{ft}$ thick. Four persistent and several nonpersistent anthracite beds have been identified. The four persistent coal beds are Lykens Valley Nos. 3, 2, 1-1/2, and 1 (figs. 2 and 3). The Sharp Mountain Member is about $400 \mathrm{ft}$ thick, is composed chiefly of coarse conglomerate, and contains several non-persistent coal beds in the study area (figs. 2 and 3). Noncoal-bearing strata include fine- to coarse-grained sandstone, conglomerate, conglomeratic sandstone, shale, and siltstone (Wood and others, 1969). Pebbles in conglomerate and conglomeratic rocks are composed largely of vein quartz and quartzite. Cementing media include silica, sericite, unidentified clay minerals, and calcite (Wood and others, 1969).

The Llewellyn Formation overlies the Sharp Mountain member of the Pottsville Formation. The base of this formation is the base of the shale or underclay below the No. 5 coal bed or, where the shale is absent, at the base of the coal (figs. 2 and 3). The upper limit of the Llewellyn is the present erosional surface except where covered by talus (Wood and others, 1986). Although as many as 40 coal seams are present in the west-central part of the Southern Anthracite Coal Field (Wood and others, 1969) approximately 15 are persistent in the study area (figs. 2 and 3). Thickness ranges from $400 \mathrm{ft}$ in the lower part of Bear Creek watershed to 2,400 ft thick in the headwaters (figs. 2 and 3). The lithology of non-coal-bearing strata is characterized by scattered conglomerate, conglomeratic sandstone, and fine- to coarse-grained sandstone (Wood and Trexler, 1968). The rocks of the Llewellyn Formation are cemented principally by silica, sericite, and silt- and clay-sized fragments of quartz and carbonaceous material.

\section{Mining History and Techniques}

The Pottsville and Llewellyn Formations hold some of the richest anthracite reserves in the United States (Wood and others, 1969). The anthracite mining industry became economically important between 1825 and 1835 (Wood and others, 1969), owing to demand from a growing steel industry supplied by a new railroad network that extended throughout eastern Pennsylvania, Delaware, New Jersey, and Maryland. These developments provided the market and infrastructure for largescale coal-mining operations that continued into the 1930s. The collier chiefly responsible for coal extraction within and underlying the Bear Creek watershed was the Lykens-Williamstown 

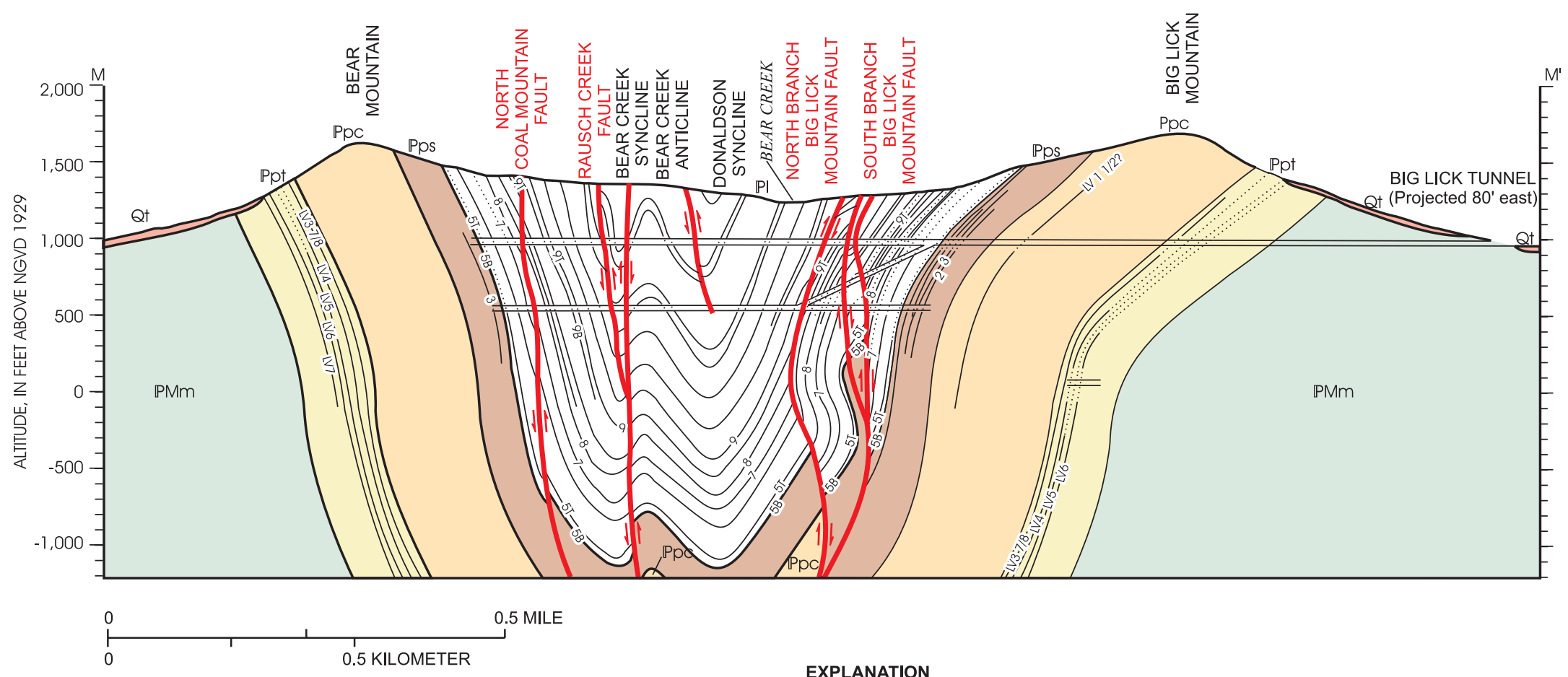

EXPLANATION

\begin{tabular}{|c|c|}
\hline$Q^{\dagger}$ & \\
\hline TALUS & \\
\hline $\mathbb{P I}$ & \\
\hline \multicolumn{2}{|c|}{ LLEWELLYN FORMATION } \\
\hline Pps & Sharp Mountain Member \\
\hline Ppc & Schuylkill Member \\
\hline Ppt & Tumbling Run Member \\
\hline \multicolumn{2}{|c|}{ POTTSVILLE FORMATION } \\
\hline PMm & \\
\hline
\end{tabular}

COAL BED - Solid were accurately located by underground mining. Number designates coal bed; T, top split; B, bottom split; LV Lykens Valley

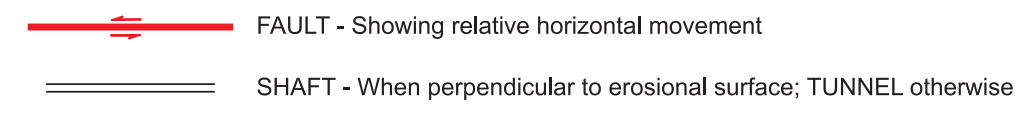

Figure 2. Geologic cross section M-M' showing anthracite coal-bearing strata in Bear Creek watershed, Dauphin County, Pennsylvania. Location of section is shown on figure 1. Cross section is adapted from Wood and Trexler (1968). 


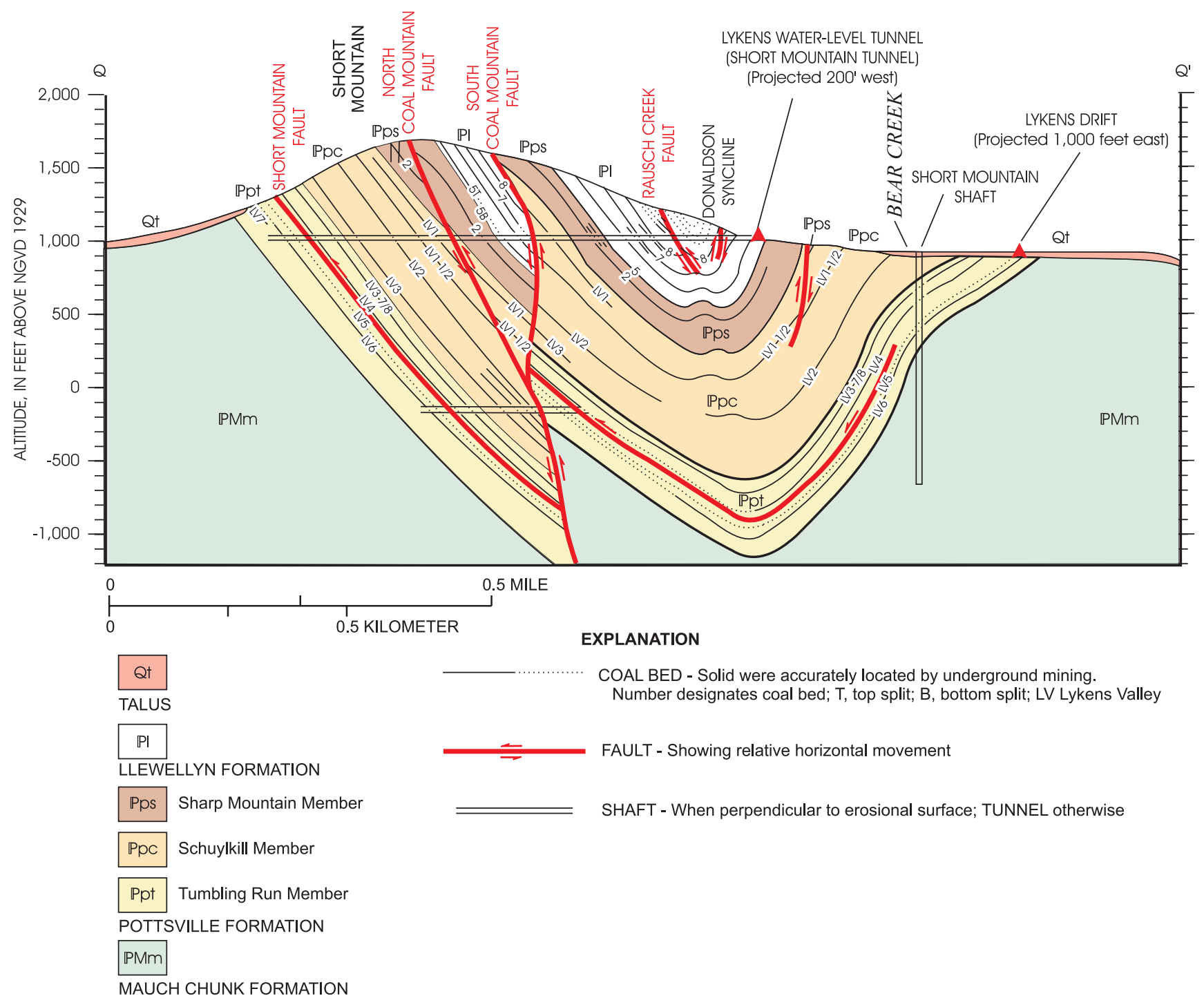

Figure 3. Geologic cross section 0-Q' showing anthracite coal-bearing strata in Bear Creek watershed, Dauphin County, Pennsylvania. Location of section is shown on figure 1. Cross section is adapted from Wood and Trexler (1968). The Lykens Water-Level Tunnel is referred to as Short Mountain Tunnel by Wood and Trexler (1968).

Mine of the Rhoads Contracting Company (Ash and Kynor, 1953).

The Lykens-Williamstown Mine is bounded by the lowest workable coal bed (LV7 where present, otherwise LV6) and is adjoined by the Valley View and Brookside Mines to the east (fig. 1). Valley View Mine is north of and adjacent to Brookside Mine; however, the exact boundary is unclear and is therefore not shown on figure 1 . The boundary between the Lykens-Williamstown Mine and the adjoining mines is the mine pool boundary where no barrier pillars exist. Where no adjoining mines are present, the boundary of Lykens-Williamstown Mine is the lowest workable coal bed (fig. 1).

Strip mining, the removal of coal from surface outcroppings, was utilized wherever coal was accessible at or near the erosional surface, mainly on the south-facing slope of Bear Mountain, north and south-facing slopes of Short Mountain, and the north slope of Big Lick Mountain. Overburden (overlying nonmarketable strata) was removed with power shovels and bulldozers and typically discarded on the downslope side. Coal extraction generally progressed until the mine depth restricted the use of machinery, rendering the method unprofitable. Coal seams 9T, 9, 8, 7, 5T, LV6, LV5, LV4, and LV3 7/8 (figs. 2 and 3) were strip mined (Wood and others, 1969).

Drift mining was employed where multiple entries in close proximity could be excavated into an outcropping coal bed that did not dip too steeply (less than $20^{\circ}$ inclination from horizontal) (Wood and others, 1969). Drift entries can extend for hundreds of feet until they are eventually connected by cross entries 
(Sanders and Thomas, Inc., 1973). This type of mining results in a framework of rooms and pillars by excavating "rooms" supported by "pillars" that are left in place. Log timbers commonly were used as additional support. After completion of a series of rooms and removal of excavated coal, the pillars generally were removed or "robbed," usually resulting in collapse of the workings. Lykens Drift (fig. 1) and adjacent seeps are a result of drift mining.

Deep mining is similar to drift mining in that it involves coal extraction by tunneling into and excavating rooms and pillars from a coal bed. This method typically was used where the dip of the coal bed was greater than $20^{\circ}$. Shafts are excavated such that they follow the dip of the coal bed and are used for access and extraction. Approximately 15 shafts in or close to the Bear Creek watershed were identified by Wood and Trexler (1968). Some of these have been backfilled through various reclamation efforts or mass wasting of unsupported, adjacent strata, but shafts that have not been backfilled are still present (Skelly and Loy, Inc., 2003). Coal seams mined too close to the surface commonly collapse leaving a hole that may extend hundreds of feet. If these openings are not sealed by collapse of adjacent strata or by human intervention, they provide direct access for surface runoff to enter the underground mine workings. These holes are referred to as "crop falls." Most crop falls are sealed at the bottom with soil and rock, but about eight remain open and may extend hundreds of feet underground.

\section{Origin of Mine Water}

Underground mining has resulted in a vast series of voids in the numerous mined coal beds that are interconnected at many places but are isolated at others. This series of voids and associated tunnels, drifts, and shafts are collectively referred to as mine workings. During active mining, water was pumped from the mine workings to keep infiltration from the surface and ground water out of the mine. These efforts allowed coal extraction to proceed well below the local ground-water table; in fact, well below sea level (Wood and others, 1969). It commonly is reported that mining in the Bear Creek watershed ceased sometime in the 1930s (Ash and others, 1949; Wood and others, 1969; Sanders and Thomas, Inc., 1973). Around this time, pumping also ceased and the workings flooded with water creating the Lykens-Williamstown Mine Pool. The workings may be completely flooded in places or may be discontinuously flooded in a vertical and horizontal plane. Vertical barrier pillars were left between mines to minimize inter-mine infiltration, but when mining efforts were abandoned, the pillars commonly were breached by robbing any remaining coal. Barrier pillars between the Lykens-Williamstown Mine and the adjoining Brookside and Valley View Mines (fig. 1) were not breached as recently as 1953 (Ash and Kynor, 1953) and may still provide an effective barrier to inter-mine seepage. The present condition of these pillars is unknown, and therefore, the degree of interconnection between the Lykens-Williamstown Mine and the adjoining mines is unknown.
The Lykens-Williamstown Mine Pool receives water from two known sources: (1) direct connection with the surface through the original mine openings and fractures in overlying strata, and (2) ground-water seepage from adjacent strata. Seepage from the Brookside Mine Pool to the Lykens-Williamstown Mine Pool is another possible source depending on the condition of the barrier pillar between these pools.

Surface runoff is conveyed through abandoned stripping operations, crop falls, and subsidence depressions, which are common features throughout the watershed. Fractures in strata overlying the mine workings increase infiltration of runoff across the entire area and are of particular concern where the streambed is intercepted. Nonetheless, a study completed by Skelly and Loy, Inc. (2003) indicates water entering the mine pool through mine openings accounts for only about 13 percent of mine water discharged to Bear Creek. Because there was no interflow between adjacent mines as late as 1953 (Ash and Kynor, 1953) and conveyance through surface openings accounts for 13 percent of mine discharge to Bear Creek, the majority of water entering the mine workings is likely provided by ground-water seepage from adjacent strata.

Water entering the mine workings is the reaction and transport medium for the reaction products of metal-bearing minerals. Pyrite (chemically described as iron sulfide $\left(\mathrm{FeS}_{2}\right)$ ) is common in coal-bearing strata (Stumm and Morgan, 1996) and is the principal source of iron, the contaminant that has the largest effect on the habitat water quality of Bear Creek. Siderite $\left(\mathrm{FeCO}_{3}\right)$ also may be a source of iron and is notable as a source of manganese when manganese substitutes for iron (Morrison and others, 1990) to form manganosiderite $\left[(\mathrm{Fe}, \mathrm{Mn}) \mathrm{CO}_{3}\right](\mathrm{Cra}-$ votta and others, 1994). Manganese oxides are also sources of manganese in sedimentary rocks (Hem, 1985, p. 88-89). Other metals, including aluminum, can originate from the dissolution of aluminosilicate minerals (Cravotta, 1991). Because iron is the metal that has the largest effect on the water quality of Bear Creek, the following discussion focuses on iron production via the oxidation of pyrite.

Mining techniques described above expose the surface of pyrite-bearing strata, subjecting it to oxidation. Pyrite oxidation is characterized by the following reaction in which pyrite, oxygen, and water react to form ferric hydroxide $\left(\mathrm{Fe}(\mathrm{OH})_{3}(\mathrm{~s})\right)$, sulfate $\left(\mathrm{SO}_{4}{ }^{2-}\right)$, hydrogen ion $\left(\mathrm{H}^{+}\right)$, and heat:

$$
\begin{aligned}
\mathrm{FeS}_{2}(\mathrm{~s})+3.75 \mathrm{O}_{2} & +3.5 \mathrm{H}_{2} \mathrm{O}=\mathrm{Fe}(\mathrm{OH})_{3}(\mathrm{~s})+2 \mathrm{SO}_{4}{ }^{2-} \\
+ & 4 \mathrm{H}^{+}+\text {heat }
\end{aligned}
$$

The presence of ferrous iron $\left(\mathrm{Fe}^{2+}\right)$ in mine-discharge samples collected during this study indicates the chemical reactions are at intermediate stages in a series of reactions that collectively represent pyrite oxidation (Rose and Cravotta, 1998). The following reactions characterize various stages in the complete reaction (Stumm and Morgan, 1996):

$$
\begin{gathered}
\mathrm{FeS}_{2}(\mathrm{~s})+3.5 \mathrm{O}_{2}+\mathrm{H}_{2} \mathrm{O}=\mathrm{Fe}^{2+}+2 \mathrm{SO}_{4}{ }^{2-}+2 \mathrm{H}^{+} \\
\mathrm{Fe}^{2+}+0.25 \mathrm{O}_{2}+\mathrm{H}^{+}=\mathrm{Fe}^{3+}+0.5 \mathrm{H}_{2} \mathrm{O}
\end{gathered}
$$




$$
\begin{gathered}
\mathrm{Fe}^{3+}+3 \mathrm{H}_{2} \mathrm{O}=\mathrm{Fe}(\mathrm{OH})_{3}(\mathrm{~s})+3 \mathrm{H}^{+} \\
\mathrm{FeS}_{2}(\mathrm{~s})+14 \mathrm{Fe}^{3+}+8 \mathrm{H}_{2} \mathrm{O}=15 \mathrm{Fe}^{2+}+2 \mathrm{SO}_{4}^{2-}+16 \mathrm{H}^{+}
\end{gathered}
$$

Oxidation of $\mathrm{FeS}_{2}$ releases $\mathrm{SO}_{4}{ }^{2-}, \mathrm{Fe}^{2+}$, and $\mathrm{H}^{+}$into the water (eqn. 2). Dissolved $\mathrm{Fe}^{2+}$ undergoes oxidation to $\mathrm{Fe}^{3+}$ (eqn. 3), which then hydrolyzes to form various amorphous oxide, hydroxide, or oxyhydroxysulfate precipitates, nominally designated here as $\mathrm{Fe}(\mathrm{OH})_{3}$ (s) (eqn. 4). $\mathrm{Fe}^{3+}$ can also be reduced by $\mathrm{FeS}_{2}(\mathrm{~s})$, where $\mathrm{FeS}_{2}(\mathrm{~s})$ is again oxidized and $\mathrm{Fe}^{2+}$ is produced and may re-enter the reaction cycle via equation 3 (Stumm and Morgan, 1996).

Water drains from the Lykens-Williamstown Mine Pool from the following known sources in Bear Creek watershed: (1) LWLT, (2) LD, and (3) diffuse zones of seepage. The LWLT extends north underneath Short Mountain where it connects to the Lykens-Williamstown Mine Pool. Mine drainage is discharged from the tunnel (fig. 4) onto the east-facing slope of Short Mountain and cascades downslope for approximately $200 \mathrm{ft}$ until its confluence with an unnamed tributary on the west side of Bear Creek. The mixed waters are conveyed within the unnamed tributary for approximately $50 \mathrm{ft}$ before joining Bear Creek.

The LD (fig. 5) is a drift opening that extends horizontally underneath Short Mountain where it intercepts the mine pool.
Mine drainage is discharged approximately $50 \mathrm{ft}$ to the west of Bear Creek where it cascades over deposits of solid iron precipitate before entering the creek.

Currently (2004), there are at least three perennially flowing zones of diffuse mine seepage in the watershed. Intermittent zones of seepage have not been enumerated. The largest zone of diffuse seepage is adjacent to the LD. Historically four separate sources were reported near LD in an assessment of Wiconisco Creek watershed in 1973 (Sanders and Thomas, Inc., 1973). This suggests the present seepage shown in figure 6 is a mixture of several seeps from remnant drift openings that have been covered over with fill or have collapsed. Mine drainage from this seepage cascades over deposits of solid iron precipitate before entering Bear Creek.

The Lykens-Williamstown Mine Pool is also drained by Big Lick Tunnel, which extends under Big Lick Mountain and Bear Valley (figs. 2 and 3). Big Lick Tunnel discharges to Wiconisco Creek upstream of Bear Creek and was not sampled directly during this study because its source is outside of the Bear Creek watershed (fig. 1). However, because it drains the same mine pool that contributes drainage to Bear Creek, Big Lick Tunnel reduces mine drainage to Bear Creek and increases flow and mine-related contaminants measured at WC-UBC.

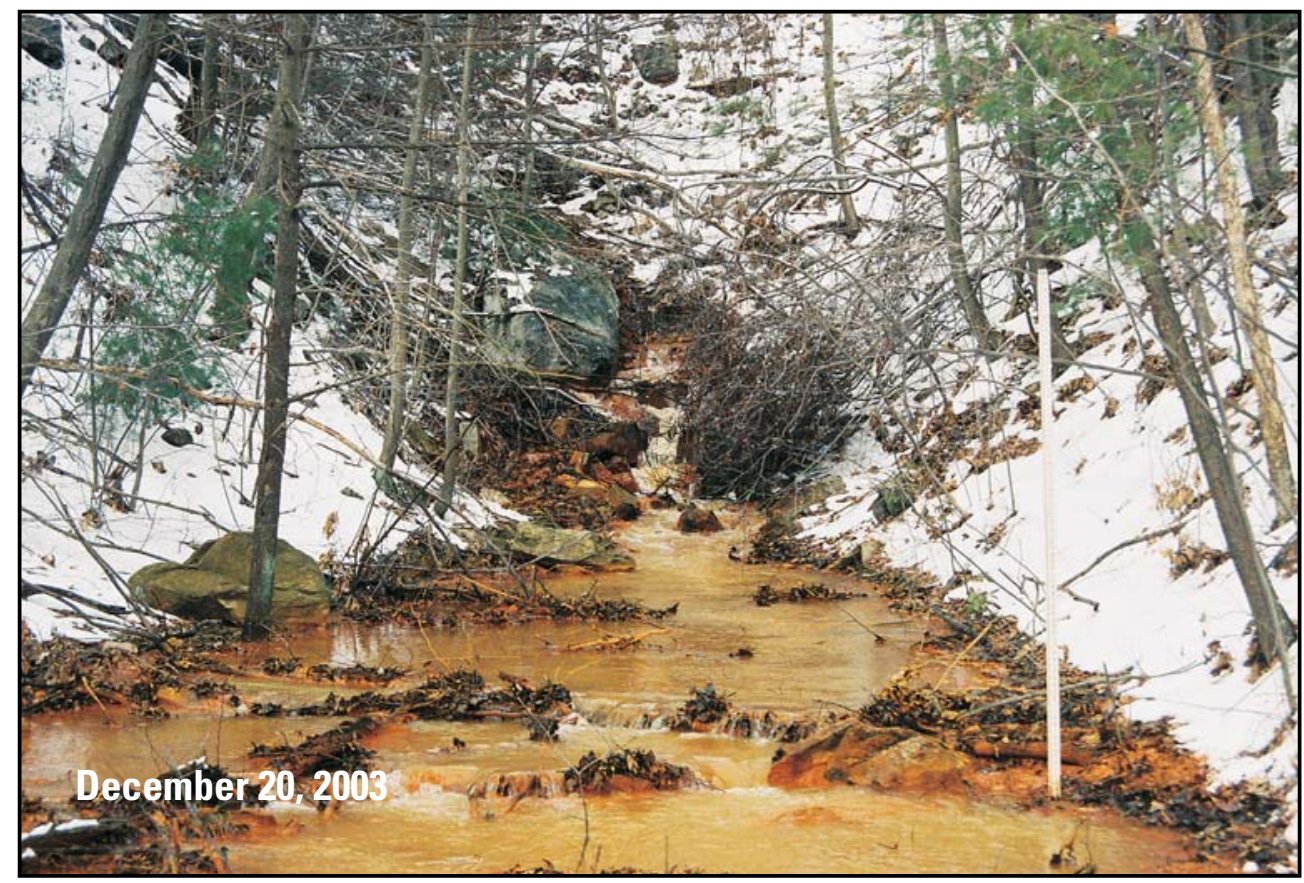

Figure 4. Mine drainage discharging from the Lykens Water-Level Tunnel (LWLT) in Bear Creek watershed, Dauphin County, Pennsylvania. Picture taken looking toward the source of the mine drainage. The survey rod on the right is intended for scale and extends $8 \mathrm{ft}$ above the ground surface. See figure 1 for the location of LWLT. 


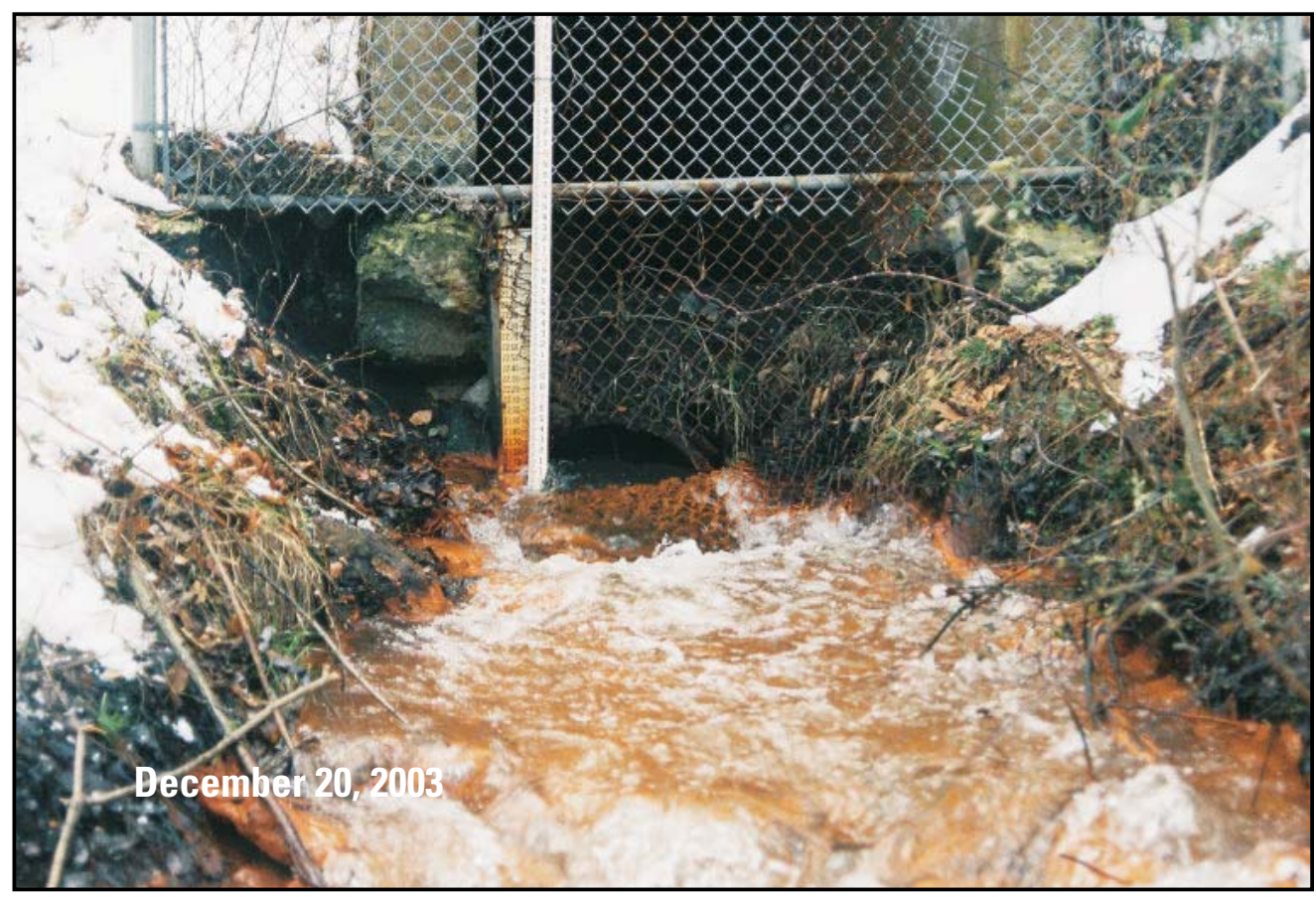

Figure 5. Mine drainage discharging from the Lykens Drift (LD) discharge in Bear Creek watershed, Dauphin County, Pennsylvania. Picture taken looking toward the source of the mine drainage. The survey rod near the center is intended for scale and extends $4 \mathrm{ft}$ above the water surface.

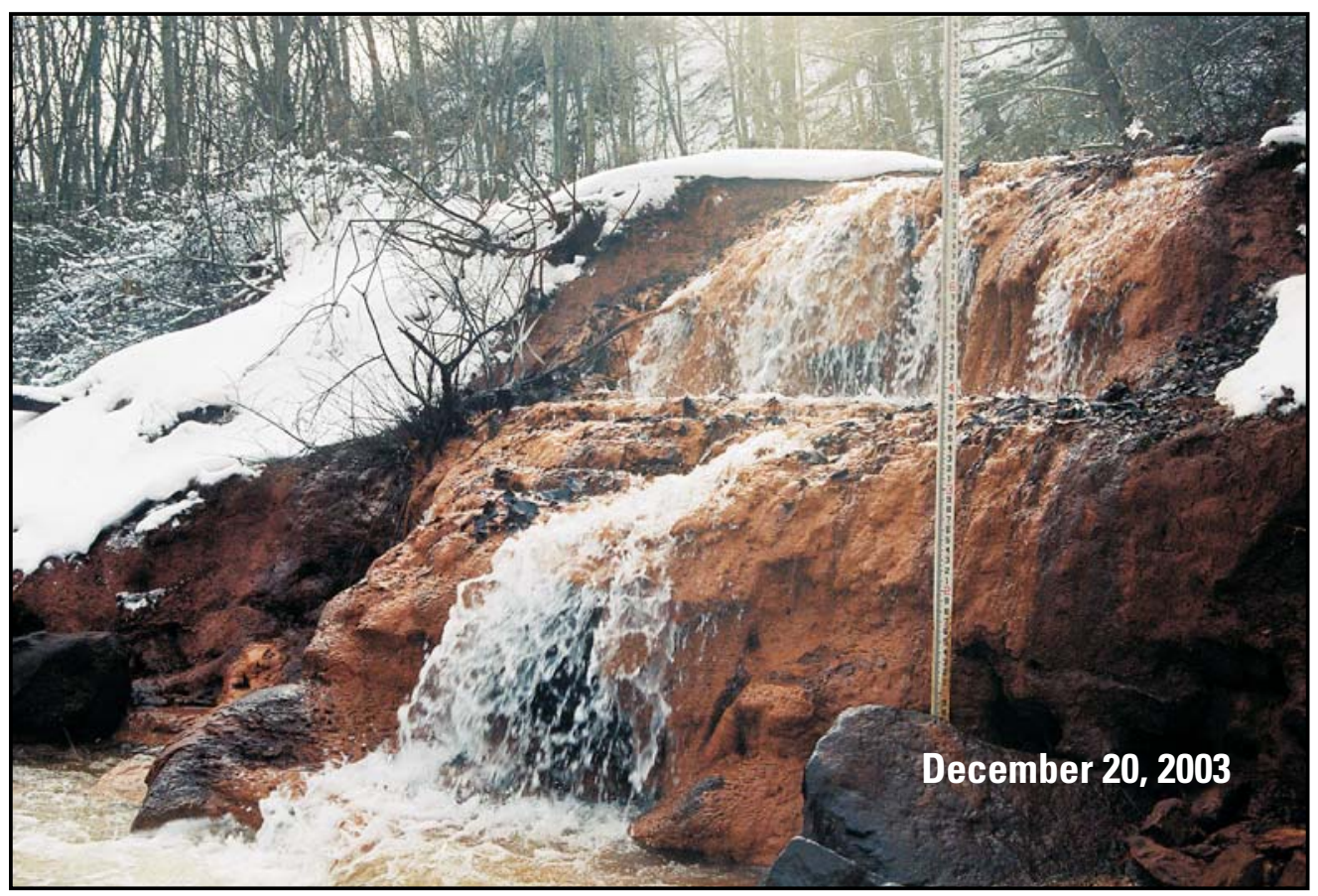

Figure 6. Mine drainage from several seeps adjacent to the Lykens Drift discharge in Bear Creek watershed, Dauphin County, Pennsylvania. Picture taken looking at the confluence of the seeps and Bear Creek. The survey rod on the right is intended for scale and extends $7 \mathrm{ft}$ above the boulder. 


\section{Previous Investigations of Mine Drainage in Bear Creek Watershed}

The long history of anthracite coal mining has led to many detailed studies of regional geology, hydrology, and miningrelated contamination. Many of these studies include information on Bear Creek watershed although Bear Creek itself has been the sole focus of only two studies (Skelly and Loy, Inc., 2003; Susquehanna River Basin Commission, 2001). The collective information garnered from each of the following reports assists in understanding the watershed today.

Ash and others (1949) present data on location, altitude, and water volume of the Lykens-Williamstown Mine Pool. The location of the Lykens-Williamstown Mine Pool published in Ash and others (1949) is superimposed onto the study location map in figure 1. Ash and others (1949) reported that the Lykens-Williamstown Mine Pool surface altitude was $897 \mathrm{ft}$ (NGVD 29) and that storage volume was 980 million $\mathrm{ft}^{3}$ (7.33 bgal) of water.

Several investigations have documented mine drainage in Bear Creek. Sanders and Thomas, Inc. (1973) identified six separate sources of mine discharge throughout Bear Creek watershed, characterized the water quality of each, and suggested remedial alternatives to mitigate water-quality degradation. Some of the sources identified by Sanders and Thomas, Inc. (1973) are probably ephemeral and were not flowing during this study. Others may have become diffuse zones of seepage due to the collapse of earth or man-made barriers that once separated them.

Growitz and others (1985) and Wood (1996) published water-quality data from the LWLT and LD as part of an assessment of mine drainage in the Anthracite Coal Region. Additional data for flow, major cations and anions, metals, and other constituents were collected by PaDEP at site LWLT beginning in April 1997 and are available through the World Wide Web (U.S. Geological Survey, 2005). Stoe (1998) assessed the water quality and aquatic macroinvertebrate community of Bear Creek and found that no macroinvertebrates were present because of poor water quality.

More recent investigations have utilized data collected during this investigation and data of previous studies. Hedin Environmental $(1998,2001)$ presented designs of aerobic wetlands to passively treat discharges from LWLT and LD. The Susquehanna River Basin Commission (SRBC) (2001) determined the TMDLs of selected constituents that should not be exceeded to return Bear Creek to a cold-water fishery. A water budget completed in 2002 (Skelly and Loy, Inc., 2003) determined the amount of surface runoff entering mine-subsidence features. Skelly and Loy, Inc., (2003) also assessed the feasibility of various remediation alternatives for Bear Creek and concluded that the best alternative for removal of iron from drainage at sites LWLT and LD was passive treatment with aerobic ponds.

\section{Study Design and Methods}

This study design provides the chemical and hydrologic data necessary to determine the effects of historical coal mining and drainage from abandoned mines on Bear Creek and its receiving waters, Wiconisco Creek. The effects of historical coal mining on streamflow were evaluated on the basis of streamflow loss in Bear Creek under low-flow and high-flow conditions. The effects of drainage from abandoned mines were evaluated on the basis of differences in selected constituents between sites. A two-sided Wilcoxon signed-rank test (Helsel and Hirsch, 2002) was used to determine significant differences between sites within three matched pairs (BC-UMD compared to BC-DMD, BC-DMD compared to BCM, and WC-UBC compared to WC-DBC) (table 2). A two-sided Wilcoxon ranksum test (Helsel and Hirsch, 2002) was used to determine significant differences between sites LWLT and LD. This test was chosen over the Wilcoxon signed-rank test because LWLT and $\mathrm{LD}$ are considered independent and therefore pairing is not appropriate. The null hypothesis for both tests is that there is no difference between median values of compared sites. For this study, the null hypothesis is rejected if the p-value (probability that a difference occurs by chance) is less than 0.05 .

Hydrologic and chemical data were collected by USGS at nine sites in the Bear Creek watershed and two sites on Wiconisco Creek (table 2) to characterize flow and chemistry at the following locations: (1) the headwaters of Bear Creek (sites BCH-A, BCH-B, BCH-C, BCH-D); (2) Bear Creek upstream of mine drainage (BC-UMD); (3) at the largest mine discharges (sites LWLT and LD); (4) Bear Creek immediately downstream of mine discharges (site BC-DMD); (5) at the mouth of Bear Creek (site BCM); and (6) Wiconisco Creek upstream and downstream of Bear Creek (sites WC-UBC and WC-DBC, respectively) (fig. 1). Sites $\mathrm{BCH}-\mathrm{A}, \mathrm{BCH}-\mathrm{B}, \mathrm{BCH}-\mathrm{C}$, and $\mathrm{BCH}-\mathrm{D}$ were monitored once during high streamflow and once during low streamflow for the specific purpose of quantifying streamwater losses to the underground mine pool. Chemically, sites $\mathrm{BCH}-\mathrm{A}, \mathrm{BCH}-\mathrm{B}, \mathrm{BCH}-\mathrm{C}$, and $\mathrm{BCH}-\mathrm{D})$ are very similar to one another and to site BC-UMD. Because more data were collected at site BC-UMD and it is representative of the chemistry observed at the four headwater sites, statistical summaries of chemical data collected at the headwater sites are not included in this report. At sites BC-UMD, LWLT, LD, and BC-DMD, instantaneous flow and chemistry data were collected intermittently by USGS from March 1999 to September 1999, then monthly from October 1999 to December 2002. Measurements of instantaneous flow and chemistry at site LWLT were made monthly from March 1999 to August 1999 by PaDEP. Instantaneous flow and chemistry at site BCM was measured monthly from October 1999 to December 2002. Site BCM represents the integration of all mine discharges and unpolluted flow from upstream prior to mixing with Wiconisco Creek. The Wiconisco Creek sites were established $50 \mathrm{ft}$ upstream (WC-UBC) and $200 \mathrm{ft}$ downstream (WC-DBC) of Bear Creek and were 
Table 2. Sampling sites in the Bear Creek and Wiconisco Creek watersheds, Dauphin County, Pennsylvania.

$\left[\mathrm{mi}^{2}\right.$, square miles; ft, feet; --, not determined]

\begin{tabular}{|c|c|c|c|c|c|c|}
\hline $\begin{array}{c}\text { U.S. Geological } \\
\text { Survey station } \\
\text { identification } \\
\text { number }^{1}\end{array}$ & Description & Acronym & $\begin{array}{c}\text { Drainage } \\
\text { area } \\
\left(\mathrm{mi}^{2}\right)\end{array}$ & $\begin{array}{c}\text { Altitude }^{2} \\
\text { (ft) }\end{array}$ & Latitude $^{3}$ & Longitude $^{3}$ \\
\hline 01555527 & Wiconisco Creek upstream of Bear Creek & WC-UBC & 28.8 & 670 & $40^{\circ} 34^{\prime} 10^{\prime \prime}$ & $76^{\circ} 41^{\prime} 55^{\prime \prime}$ \\
\hline 01555532 & Bear Creek at headwaters - A & $\mathrm{BCH}-\mathrm{A}$ & 2.20 & 1,210 & $40^{\circ} 35^{\prime} 38^{\prime \prime}$ & $76^{\circ} 40^{\prime} 01^{\prime \prime}$ \\
\hline 01555534 & Bear Creek at headwaters - B & $\mathrm{BCH}-\mathrm{B}$ & 2.98 & 1,200 & $40^{\circ} 35^{\prime} 25^{\prime \prime}$ & $76^{\circ} 40^{\prime} 59^{\prime \prime}$ \\
\hline 01555535 & Bear Creek at headwaters - C & $\mathrm{BCH}-\mathrm{C}$ & 3.16 & 1,190 & $40^{\circ} 35^{\prime} 19^{\prime \prime}$ & $76^{\circ} 41^{\prime} 14^{\prime \prime}$ \\
\hline 01555536 & Bear Creek at headwaters - D & BCH-D & 3.64 & 1,010 & $40^{\circ} 35^{\prime} 07^{\prime \prime}$ & $76^{\circ} 41^{\prime} 53^{\prime \prime}$ \\
\hline 01555537 & Bear Creek upstream of mine drainage & BC-UMD & 4.27 & 970 & $40^{\circ} 35^{\prime} 04^{\prime \prime}$ & $76^{\circ} 41^{\prime} 59^{\prime \prime}$ \\
\hline 01555539 & Bear Creek downstream of mine drainage & BC-DMD & 4.44 & 820 & $40^{\circ} 34^{\prime} 46^{\prime \prime}$ & $76^{\circ} 41^{\prime} 59^{\prime \prime}$ \\
\hline 01555540 & Bear Creek at mouth & $\mathrm{BCM}$ & 4.70 & 675 & $40^{\circ} 34^{\prime} 11^{\prime \prime}$ & $76^{\circ} 41^{\prime} 55^{\prime \prime}$ \\
\hline 01555541 & Wiconisco Creek downstream of Bear Creek & WC-DBC & 33.9 & 670 & $40^{\circ} 34^{\prime} 11^{\prime \prime}$ & $76^{\circ} 42^{\prime} 01^{\prime \prime}$ \\
\hline 403448076420001 & Lykens Drift & LD & -- & 880 & $40^{\circ} 34^{\prime} 50^{\prime \prime}$ & $76^{\circ} 41^{\prime} 60^{\prime \prime}$ \\
\hline 403504076415901 & Lykens Water-Level Tunnel & LWLT & -- & 980 & $40^{\circ} 35^{\prime} 06^{\prime \prime}$ & $76^{\circ} 41^{\prime} 59^{\prime \prime}$ \\
\hline
\end{tabular}

${ }^{1}$ U.S. Geological Survey station identification number is assigned based on watershed position for surface-water sites or latitude and longitude for mine-drainage sites. U.S. Geological Survey station identification number can be used to cross-reference this report with U.S. Geological Survey Annual Water-Data Reports published by Durlin and Schaffstall (2001, 2002, 2003). Data are available via the World Wide Web at http://pa.waterdata.usgs.gov/ nwis/.

${ }^{2}$ Altitude was determined from the Lykens, Pennsylvania, 7.5-minute topographic quadrangle published by the U.S. Geological Survey. Vertical datum is National Geodetic Vertical Datum of 1929. Accuracy is $\pm 10 \mathrm{ft}$.

${ }^{3}$ Horizontal datum is North American Datum of 1983. Coordinates previously published in Durlin and Schaffstall $(2001,2002,2003)$ may differ slightly because they are referenced to the North American Datum of 1927.

monitored monthly from July 2001 to December 2002 to characterize changes in the flow and chemistry after mixing with Bear Creek.

Determination of flow rate was used to assess hydrologic losses at or inputs to each site. Streamwater loss was quantified by synoptic measurements of instantaneous flow rate at $\mathrm{BCH}-\mathrm{A}$ and all downstream sites on Bear Creek on two occasions, under sustained high-flow conditions (March 2001) and sustained low-flow conditions (August 2001). A continuous record of streamflow was computed at BC-DMD from March 1999 to December 2002. Because site BC-DMD is immediately downstream of mine inputs, calculation of the proportion of flow from upstream sources is possible. The continuous record of streamflow at BC-DMD was computed on the basis of water levels (stage) recorded every 15 -minutes with a pressure transducer. Instantaneous flow-rate computations were made over a range of stages to develop an empirical stage-discharge relation following Rantz and others (1982a, 1982b). The stage-discharge relation and continuous measurements of water level were used to compute a continuous record of flow rate at BC-DMD.

Instantaneous flow at BC-UMD, LWLT, LD, BC-DMD, BCM, WC-UBC, and WC-DBC was determined by one of three methods: (1) from streamflow velocity measurements conducted with a vertical-axis current meter following standard methods (Rantz and others, 1982a); (2) by difference; or (3) by stage-discharge relations developed at BC-UMD, LWLT, LD,
BC-DMD, and BCM following Rantz and others (1982a, 1982b).

Precipitation in the Bear Creek watershed was estimated from two nearby gages, one at DeHart Reservoir Dam and one at Harrisburg International Airport (HIA) (Northeast Regional Climate Center, 2003). DeHart Reservoir Dam is approximately 8.5 mi south-southwest of Bear Creek and HIA is approximately 26 mi south-southwest of Bear Creek. The DeHart gage began operating in June 1999; the HIA gage has 55 years of record. Because of the length of record at the HIA gage, it is used to provide a historical context for precipitation measured at DeHart Reservoir Dam.

Water-chemistry samples were collected manually as grab samples from well-mixed zones in the stream following Ward and Harr (1990). Although iron, manganese, and aluminum are the principal metal pollutants in Bear Creek, sodium also was determined because it is transported conservatively and can be helpful to distinguish the chemical signature of each site. Samples analyzed for metals and sulfate were collected in $125-\mathrm{mL}$ acid-rinsed polyethylene bottles. Water analyzed for dissolved metals and sulfate was forced through a membrane filter with $0.45-\mu \mathrm{m}$ pores using a syringe plunger prior to acidification. Nitric acid was used to preserve samples analyzed for metals and sulfate, except for $\mathrm{Fe}^{2+}$ samples, which were preserved with hydrochloric acid. Water analyzed for ANC and acidity was unfiltered and was collected in non-acidified $500-\mathrm{mL}$ polyethylene bottles. All samples were stored at approximately $4^{\circ} \mathrm{C}$ during transport and shipping. 


\section{Effects of Coal Mining and Drainage From Abandoned Mines on Streamflow and Water Quality, Bear Creek, $1999-2002$}

Field measurements of $\mathrm{pH}$, specific conductance, dissolved oxygen, temperature, reduction-oxidation potential (Eh), and turbidity were made with a calibrated Yellow Springs Instruments (YSI) multi-parameter sonde following Wilde and others (1998). Each meter was calibrated prior to use according to the manufacturers specifications. Ferrous iron was analyzed colorimetrically following methods described in $\mathrm{HACH}$ Company (2003) at the USGS Pennsylvania District Laboratory in New Cumberland, Pa.

Samples collected at all sites between October 1999 and December 1999 and duplicates collected in July 2002 were analyzed by the USGS National Water-Quality Laboratory (NWQL). The NWQL determined concentrations of total sodium, dissolved sulfate, total aluminum, total and dissolved iron, and total and dissolved manganese. Total metals concentrations include the suspended fraction (such as suspended $\left.\mathrm{Fe}(\mathrm{OH})_{3}(\mathrm{~s})\right)$. Hence, the difference between total and dissolved concentrations represents the concentration suspended in the water column. Unfiltered samples were analyzed for total metals concentrations by inductively coupled plasma (ICP) spectrometry following Garbarino and Struzeski (1998). Dissolved sulfate was analyzed following Fishman and Friedman (1989). Analyses of filtered samples for dissolved metals was conducted by ICP spectrometry following Fishman (1993).

Samples collected at site LWLT between March and August 1999 and at all sites from January 2000 through December 2002 were analyzed by the PaDEP laboratory, except for duplicates sent to NWQL in July 2002. In addition to the constituents listed above, the PaDEP laboratory also determined the concentration of ANC, acidity, and total dissolved residue.

ANC and acidity were determined by titration to a fixed endpoint following standard methods described in Greenburg and others (1981). Water analyzed for ANC was titrated to a fixed endpoint $\mathrm{pH}$ of 3.7. Note that reported ANC values determined following Greenburg and others (1981) may be higher than ANC determined by more recently reported standard methods (Clesceri and others, 1998) that require titration to a fixed endpoint $\mathrm{pH}$ of 4.5 . For acidity determination, Greenburg and others (1981) require samples with hydrolyzable metal ions such as mine drainage to be treated with peroxide and boiled to promote oxidation of metal ions and hasten hydrolysis. Note that for samples with $\mathrm{pH} \geq 6.5$, PaDEP did not titrate the sample and reported acidity values of zero. This deviation from Greenburg and others (1981) limits acidity reporting to positive or zero values only.

Net ANC was calculated as ANC minus acidity as determined by PaDEP laboratory. Cravotta and Kirby (2004a) state that net ANC calculated in this manner may underestimate the alkalinity requirement to treat net acidic mine water and may lead to the incorrect identification of treatment alternatives and (or) inadequate treatment. Kirby (2002) and Cravotta and Kirby (2004a) suggest that acidity as determined by PaDEP laboratory should be interpreted as net acidity. To investigate the applicability of this interpretation to the mine discharges and streamwater of Bear Creek, net acidity was computed as Acidity $_{\text {calculated }}$ minus ANC. Acidity calculated $_{\text {was computed }}$ from $\mathrm{pH}$ and dissolved metals concentration in milligrams per liter as

$$
\begin{gathered}
\text { Acidity }_{\text {calculated }}\left(\mathrm{mg} / \mathrm{L} \text { as } \mathrm{CaCO}_{3}\right)=50 \cdot\left[10^{(3-\mathrm{pH})}+2 \cdot \mathrm{C}_{\mathrm{Fe}} / 55.85\right. \\
\left.+2 \cdot \mathrm{C}_{\mathrm{Mn}} / 54.94+3 \cdot \mathrm{C}_{\mathrm{Al}} / 26.98\right]
\end{gathered}
$$

where

$\mathrm{C}$ is concentration of constituent, in milligrams per liter.

For the computation of net acidity (Acidity calculated $_{\text {minus }}$ ANC), it is assumed that ANC was determined by titration to an endpoint $\mathrm{pH}$ of 4.5. Because PaDEP determined ANC by titration to an endpoint $\mathrm{pH}$ of 3.7, this assumption is violated and ANC values are higher than those that would be reported if samples were titrated to an endpoint $\mathrm{pH}$ of 4.5. This "over-reporting" is not significant for near-neutral samples with high ANC but for samples with $\mathrm{pH}$ near 4.5 , the sign of net acidity may be negative (indicating an alkaline condition) when it should actually be positive (indicating an acidic condition) or zero.

In general, there was disagreement between net acidity and acidity reported by PaDEP at site BC-UMD. Net acidity commonly indicated an alkaline condition (the sign was negative) when acidity as reported by PaDEP indicated an acidic condition (acidity reported by PaDEP was positive and greater than $\mathrm{ANC})$. This is because of relatively low $\mathrm{pH}($ median $=4.6)$ and consequent "over-reporting" of ANC at site BC-UMD. At the mine discharges and downstream sites, the magnitude of net acidity and acidity determined by PaDEP was different but both consistently predicted the same condition (either alkaline or acidic). Hence, the net acidity and acidity determined by PaDEP have the same interpretation at sites where treatment is a consideration. Therefore, for this report, acidity as determined by $\mathrm{PaDEP}$ is reported instead of Acidity calculated $_{\text {. }}$

Concentrations of total and dissolved metals were determined by ICP spectrometry following the U.S. Environmental Protection Agency (1994). Sulfate concentration was determined colorimetrically following the U.S. Environmental Protection Agency National Exposure Research Laboratory (1993). Total residue concentration was determined gravimetrically at the PaDEP laboratory by collection of suspended solids on a glass filter and drying of insoluble residue at $105^{\circ} \mathrm{C}$ (Fishman and Friedman, 1989).

Duplicate samples were collected on July 18, 2002. Each set of samples was analyzed separately for selected constituents by the PaDEP laboratory and by the NWQL. The results are shown in table 3.

The percent difference between laboratories varies by constituent and site. This could be because of differing methods of analyses, interferences at some sites, or lack of sensitivity over the range of observed concentrations. Dissolved and total manganese had the lowest range of percent differences ( -9 to 9 percent); dissolved and total iron had the largest range of percent differences (-17 to 41 percent) (table 3). The PaDEP laboratory consistently reported higher values of iron and manganese at all sites except BC-UMD. This indicates that concentrations and calculated loads presented in this report may be slightly high. 
Table 3. Comparison of selected constituents in duplicate samples analyzed separately by the Pennsylvania Department of Environmental Protection Laboratory and the U.S. Geological Survey National Water-Quality Laboratory.

[Locations of sites shown on figure 1; mg/L, milligrams per liter; $\mu \mathrm{g} / \mathrm{L}$ micrograms per liter; USGS, U.S. Geological Survey; PaDEP, Pennsylvania Department of Environmental Protection; <, less than; --, not determined. Samples collected July 18, 2002.]

\begin{tabular}{|c|c|c|c|c|c|c|c|}
\hline $\begin{array}{l}\text { Analyzing agency and } \\
\text { percent difference }\end{array}$ & $\begin{array}{l}\text { Sodium, } \\
(\mathrm{mg} / \mathrm{L})^{1}\end{array}$ & $\begin{array}{c}\text { Sulfate, } \\
\text { dissolved } \\
\text { (mg/L) }\end{array}$ & $\begin{array}{c}\text { Aluminum, } \\
\text { total } \\
(\mu \mathrm{g} / \mathrm{L})\end{array}$ & $\begin{array}{c}\text { Iron, } \\
\text { dissolved } \\
(\mu \mathrm{g} / \mathrm{L})\end{array}$ & $\begin{array}{l}\text { Iron, } \\
\text { total } \\
(\mu \mathrm{g} / \mathrm{L})\end{array}$ & $\begin{array}{c}\text { Manganese, } \\
\text { dissolved } \\
(\mu \mathrm{g} / \mathrm{L})\end{array}$ & $\begin{array}{c}\text { Manganese, } \\
\text { total } \\
(\mu \mathrm{g} / \mathrm{L})\end{array}$ \\
\hline \multicolumn{8}{|c|}{ Wiconisco Creek upstream of Bear Creek (WC-UBC) } \\
\hline PaDEP & 9.2 & 64.5 & $<200$ & 70 & 720 & 350 & 370 \\
\hline USGS & 8.6 & 67.8 & 120 & 80 & 650 & 330 & 340 \\
\hline Percent difference & -7 & 5 & -- & 13 & -11 & -6 & -9 \\
\hline \multicolumn{8}{|c|}{ Bear Creek upstream of mine drainage (BC-UMD) } \\
\hline PaDEP & .8 & 22.0 & $<200$ & 4,180 & 3,160 & 500 & 560 \\
\hline USGS & .6 & 18.2 & 70 & 4,660 & 5,390 & 550 & 590 \\
\hline Percent difference & -33 & -21 & -- & 10 & 41 & 9 & 5 \\
\hline \multicolumn{8}{|c|}{ Lykens Water-Level Tunnel (LWLT) } \\
\hline PaDEP & .8 & 69.5 & 300 & 5,960 & 11,500 & 990 & 1,010 \\
\hline USGS & .7 & 71.3 & 280 & 5,420 & 10,200 & 910 & 930 \\
\hline Percent difference & -14 & 3 & -7 & -10 & -13 & -9 & -9 \\
\hline \multicolumn{8}{|c|}{ Lykens Drift (LD) } \\
\hline PaDEP & 6.3 & 61.3 & $<200$ & 18,300 & 18,900 & 2,120 & 2,190 \\
\hline USGS & 6.0 & 60.5 & $<30$ & 16,500 & 16,400 & 2,030 & 2,060 \\
\hline Percent difference & -5 & -1 & -- & -11 & -15 & -4 & -6 \\
\hline \multicolumn{8}{|c|}{ Bear Creek downstream of mine drainage (BC-DMD) } \\
\hline PaDEP & 4.6 & 59.6 & $<200$ & 12,600 & 14,500 & 1,830 & 1,880 \\
\hline USGS & 4.5 & 62.1 & 40 & 11,800 & 13,100 & 1,750 & 1,790 \\
\hline Percent difference & -2 & 4 & -- & -7 & -11 & -5 & -5 \\
\hline \multicolumn{8}{|c|}{ Bear Creek at mouth (BCM) } \\
\hline PaDEP & 5.5 & 61.2 & $<200$ & 540 & 12,500 & 1,710 & 1,850 \\
\hline USGS & 5.3 & 63.1 & 40 & 560 & 11,200 & 1,630 & 1,730 \\
\hline Percent difference & -4 & 3 & -- & 4 & -12 & -5 & -7 \\
\hline \multicolumn{8}{|c|}{ Wiconisco Creek downstream of Bear Creek (WC-DBC) } \\
\hline PaDEP & 7.3 & 60.5 & $<200$ & 210 & 4,950 & 860 & 920 \\
\hline USGS & 7.0 & 65.3 & 80 & 180 & 4,690 & 820 & 860 \\
\hline Percent difference & -4 & 7 & -- & -17 & -6 & -5 & -7 \\
\hline
\end{tabular}

${ }^{1}$ Dissolved sodium is assumed to equal total sodium. Pennsylvania Department of Environmental Protection analyzed for total sodium. U.S. Geological Survey National Water-Quality Laboratory analyzed for dissolved sodium.

Absolute percent differences were largest in samples from site BC-UMD for all constituents except total manganese. Water at site BC-UMD has low concentrations of the selected constituents (table 3) compared to downstream sites. Lack of sensitivity at low concentration may be part of the reason for large absolute percent differences at this site. However, laboratory values from analyses of water from site WC-UBC (which has lower concentrations than site BC-UMD for most constituents) do not consistently display the same divergence in reported values. This suggests that other factors, perhaps interferences, influence the laboratory results from site BC-UMD. Regardless of the reason for large percent differences in con- centrations reported for site BC-UMD, high percent difference at low concentration has less effect and is therefore more tolerable than large percent differences at high concentration. 


\section{Effects of Historical Coal Mining on Streamflow}

Disturbance of surface and underground strata from a century of anthracite coal mining has altered the quantity and variability of streamflow in Bear Creek. Mining on and close to the erosional surface of the watershed has left large areas of unconsolidated spoil and fractures that collectively promote infiltration of surface precipitation and streamwater into the underground mine workings. Deep mining and drift techniques have created a circuitous maze of flooded voids that extends the underground area contributing water to Bear Creek well outside the surface watershed (fig. 1). The extent of the underground area draining to Bear Creek depends on the degree of interconnectedness of the Lykens-Williamstown Mine with adjacent mines (fig. 1).

Streamflow in Bear Creek originates from precipitation runoff, ground water, and drainage from abandoned mines. These sources are not mutually exclusive. Precipitation runoff or ground water may enter the stream, infiltrate through fractures in the streambed to the underlying mine pool, and overflow as mine drainage to Bear Creek from mine openings, fractures, or other discharge points lower in the watershed.

Complex interactions between precipitation, streamwater, and mine water control streamflow in Bear Creek.

The precipitation record from DeHart Reservoir Dam, approximately $8.5 \mathrm{mi}$ southwest of Bear Creek, indicated hydrologic conditions during the study period ranged from drought to above-average precipitation (fig. 7). Total precipitation at DeHart Reservoir Dam was 29 in. from June 1, 1999, to December 31, 1999; 51.2 in. in 2000; 33.02 in. in 2001; and $43.9 \mathrm{in}$. in 2002. Average annual precipitation based on 55 years of record at HIA is $40 \mathrm{in}$. (Northeast Regional Climate Center, 2003). Above-average precipitation fell in 2000 (fig. 7); drought conditions dominated in 2001, and 2002 was near average. The maximum monthly rainfall was in September 1999 as a result of three intense storm events from September 6-8 (5.3 in.), September15-17 (4.16 in.), and September 28-30 (3.26 in.).

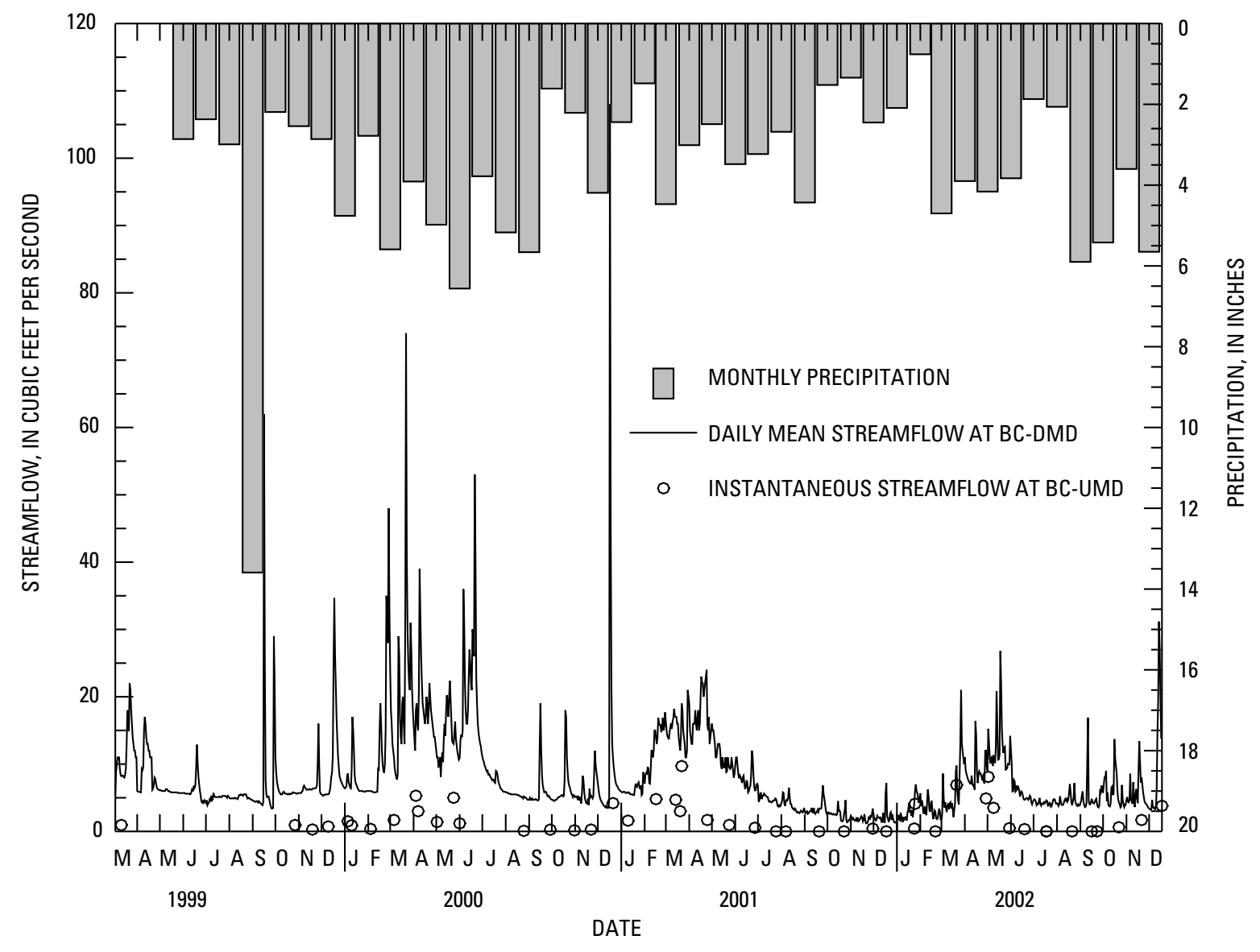

Figure 7. Streamflow hydrograph for Bear Creek downstream of mine inputs (BC-DMD) superimposed on instantaneous streamflow measurements upstream of mine inputs (BC-UMD), and precipitation measured approximately 8.5 miles southwest of Bear Creek at DeHart Reservoir Dam. Precipitation data were recorded by Northeast Regional Climate Center at Cornell University (Northeast Regional Climate Center, 2003). 
Mean streamflow for the period of record (March 1999 through December 2002) at BC-DMD was $8.4 \mathrm{ft}^{3} / \mathrm{s}$ (Durlin and Schaffstall, 2003) ${ }^{1}$. Note that the mean streamflow is the mean of daily mean values computed from continuous water-level measurements (daily mean values are plotted in fig. 7). The mean instantaneous streamflow at BC-DMD was $8.6 \mathrm{ft}^{3} / \mathrm{s}$ (table 4) and was computed as the mean of all instantaneous streamflow measurements. The fact that the mean streamflow and the mean of instantaneous measurements are nearly equal indicates the range of hydrologic conditions is well represented by the instantaneous measurements.

Streamflow at BC-DMD (fig. 7) represents an integration of the collective inputs from unimpacted sources in the headwaters of Bear Creek (measured at site BC-UMD) and drainage from the Lykens-Williamstown Mine Pool. Daily mean streamflow ranged from $1.2 \mathrm{ft}^{3} / \mathrm{s}$ on November 21 and 22, 2001, to $108 \mathrm{ft}^{3} / \mathrm{s}$ on December 17, 2000 (fig. 7). Streamflow at BC-DMD is perennial, owing to sustained drainage from LWLT, LD, and diffuse zones of seepage. When water loss upstream of the mine inputs is 100 percent, base flow in Bear Creek is entirely drainage from abandoned mines.

The general trend of the hydrograph at BC-DMD is a seasonal high flow during the winter and early spring months when evapotranspiration is least (fig. 7). Superimposed on the high seasonal flows are peaks for individual storm events. The mechanisms controlling the high seasonal flows that take place in the winter months and the storm peaks in response to precipitation are different. The seasonal high flows are controlled by an overall rise in the level of water in the Lykens-Williamstown Mine Pool resulting in more flow at sites LWLT and LD. Because of its large storage capacity (approximately 980 million $\mathrm{ft}^{3}$; Ash and others, 1949), the response of the mine-pool discharge rate, measured by drainage discharging from LWLT and LD, lags behind the response of streamflow. As a result, the magnitude of individual sharp peaks is controlled primarily by storm runoff and is independent of drainage from the mine pool.

Factors controlling the response of Bear Creek to storm runoff may include rainfall intensity, evapotranspiration, and storage capacity of headwater wetlands. Despite the maximum volume of rainfall in September 1999, the maximum daily mean streamflow of $108 \mathrm{ft}^{3} / \mathrm{s}$ was on December 17, 2000, in response to a relatively modest precipitation event totaling $3.16 \mathrm{in}$. over the period December 17-18 (fig. 7). Interception by vegetation, evapotranspiration, and excess storage capacity generally are less in the winter than in the fall. These factors may explain the storm peak of December 2000.

Streamflow measurements made at all sites on March 20, 2001, and August 7, 2001, indicate that measurable water loss occurred between BCH-C and BC-UMD (fig. 1) only during the relatively low-flow conditions of August 2001 (mean

\footnotetext{
${ }^{1}$ Streamflow data are published in Durlin and Schaffstall (2001, 2002, 2003) and are stored in the Automated Data Processing (ADAPS) database of the National Water Information System (NWIS) (U.S. Geological Survey, 2005).
}

monthly flow of $3.9 \mathrm{ft}^{3} / \mathrm{s}$ at site BC-DMD). Streamflow decreased from $0.07 \mathrm{ft}^{3} / \mathrm{s}$ at BCH-C to $0.00 \mathrm{ft}^{3} / \mathrm{s}$ at BC-UMD. Instantaneous flow measurements made during routine sampling trips at $\mathrm{BC}-\mathrm{UMD}$ during periods of below-normal precipitation concur with this finding. Water loss at BC-UMD was commonly 100 percent during the drought conditions of 2001 (fig. 7).

The same reach that lost streamwater in August $2001 \mathrm{had}$ increasing streamflow in March 2001. Streamflow at BCH-C and BC-UMD was 2.4 and $3.0 \mathrm{ft}^{3} / \mathrm{s}$, respectively. This does not exclude the possibility that streamwater continued to infiltrate over short distances between BCH-C and BC-UMD, even though there was a net increase in streamflow over the entire reach.

The streamflow-gaging station at BC-DMD was directly downstream of mine inputs; thus, it was a convenient location to determine the proportional contribution of each discharge from sites LWLT, LD, BC-UMD, and other sources. Under base-flow conditions, sites LWLT and LD together contributed 52 percent of the instantaneous mean flow at BC-DMD; unimpacted surface water from BC-UMD accounted for only 16 percent and unmeasured inputs were 32 percent (fig. 8A).

During storm events, water losses upstream of the mine drainages were counterbalanced by an increase in surface runoff. As a result, the proportion of streamflow to site BC-DMD from site BC-UMD increased to a mean of 47 percent (fig. 8B). The proportion of flow from LWLT remained nearly unchanged under stormflow conditions (17 percent compared to 19 percent), indicating that water volume at LWLT increased during storm events. This could be the result of rapid infiltration from a surface connection or surface runoff entering between the source of the discharge and the sampling point approximately $200 \mathrm{ft}$ downstream. The discharge from LD decreased from a mean of 33 percent under base-flow conditions to 25 percent under stormflow conditions (fig. 8A and B). This decrease indicated that flow volume from the site LD did not increase in response to precipitation and suggested no strong surface connection. Sources listed as "Other" in figure 8 decreased from 32 percent under base flow to 11 percent under stormflow, suggesting a poor surface-water connection. This indicates that the "other" category was largely unmeasured mine drainage instead of surface runoff.

Increases in flow rate of mine drainage caused by storm events is an important consideration for passive treatment. Increased transport of iron, the principal pollutant in mine drainage entering Bear Creek, can occur in streams that rapidly respond to storm events through scour of streambed sediments and episodic acidification (Cravotta and Bilger, 2001). Iron and trace metals generally are associated with fine streambed sediments ( $<0.063$-mm size particles), those that are most likely to be entrained and transported during rapid increases in flow. Flow data indicate that resuspension of bed sediment should not be a problem at sites LWLT or LD because these sites did not exhibit a rapid response to storms. 
Table 4. Summary of instantaneous flow data collected at nine sites on Bear Creek and two sites on Wiconisco Creek, Dauphin County, Pennsylvania, from March 1999 to December 2002.

[ft ${ }^{3}$ /s, cubic feet per second; WC-UBC, Wiconisco Creek upstream of Bear Creek; BCH-A, Bear Creek at headwaters - A; BCH-B, Bear Creek at headwaters - B; BCH-C, Bear Creek at headwaters - C; BCH-D, Bear Creek at headwaters - D; BC-UMD, Bear Creek upstream of mine drainage; LWLT, Lykens Water-Level Tunnel; LD, Lykens Drift; BC-DMD, Bear Creek downstream of mine drainage; BCM, Bear Creek at mouth; WC-DBC, Wiconisco Creek downstream of Bear Creek; N, number of instantaneous flow determinations; E, estimated; P25, 25th percentile; P75, 75th percentile; \%, percent]

\begin{tabular}{|c|c|c|c|c|c|c|c|c|c|c|c|}
\hline \multirow{2}{*}{ Statistic } & \multicolumn{11}{|c|}{ Flow $\left(\mathrm{ft}^{3} / \mathrm{s}\right)$} \\
\hline & WC-UBC & BCH-A & ВСН-B & BCH-C & BCH-D & BC-UMD & LWLT & LD & BC-DMD & ВСМ & WC-DBC \\
\hline $\mathrm{N}$ & 17 & 2 & 2 & 2 & 2 & 44 & 49 & 45 & 47 & 43 & 17 \\
\hline Maximum & 104 & 1.0 & 2.0 & 2.3 & 2.4 & 9.7 & 3.7 & 6.1 & 18 & 19 & E 116 \\
\hline Minimum & E 5.80 & E.04 & .07 & .07 & E. 01 & 0 & .41 & .40 & 3.0 & 3.7 & 11 \\
\hline Mean & 39 & -- & -- & -- & -- & 2.0 & 1.5 & 2.7 & 8.6 & 9.6 & 46 \\
\hline Median & 24 & -- & -- & -- & -- & .95 & 1.1 & 2.6 & 6.7 & 8.1 & 30 \\
\hline Standard deviation & 30 & -- & -- & -- & -- & 2.4 & .86 & 1.3 & 4.4 & 4.3 & 34 \\
\hline $\mathrm{P} 25$ & 19 & -- & -- & -- & -- & .28 & .86 & 1.7 & 5.0 & 6.3 & 24 \\
\hline P75 & 56 & -- & -- & -- & -- & 3.4 & 1.9 & 3.0 & 12 & 12 & 66 \\
\hline$\%$ censored $^{1}$ & 0 & 0 & 0 & 0 & 0 & 2 & 0 & 0 & 0 & 0 & 0 \\
\hline$\%$ computed $^{2}$ & 47 & 50 & 0 & 0 & 50 & 41 & 37 & 44 & 13 & 42 & 53 \\
\hline
\end{tabular}

${ }^{1}$ Censored refers to values preceded by a less-than sign $(<)$. One measurement of instantaneous streamflow at BC-UMD was censored at $<0.01 \mathrm{ft}^{3} / \mathrm{s}$. Because the number of censored values was low, and the population is adequately represented by 44 noncensored measurements, summary statistics were calculated by substituting 0.01 for $<0.01$.

${ }^{2}$ Indicates the percentage of values that were computed either by difference or a rating relating water level to flow (see Study Design and Methods section). Ratings were developed in accordance with methods in Rantz and others (1982b). 

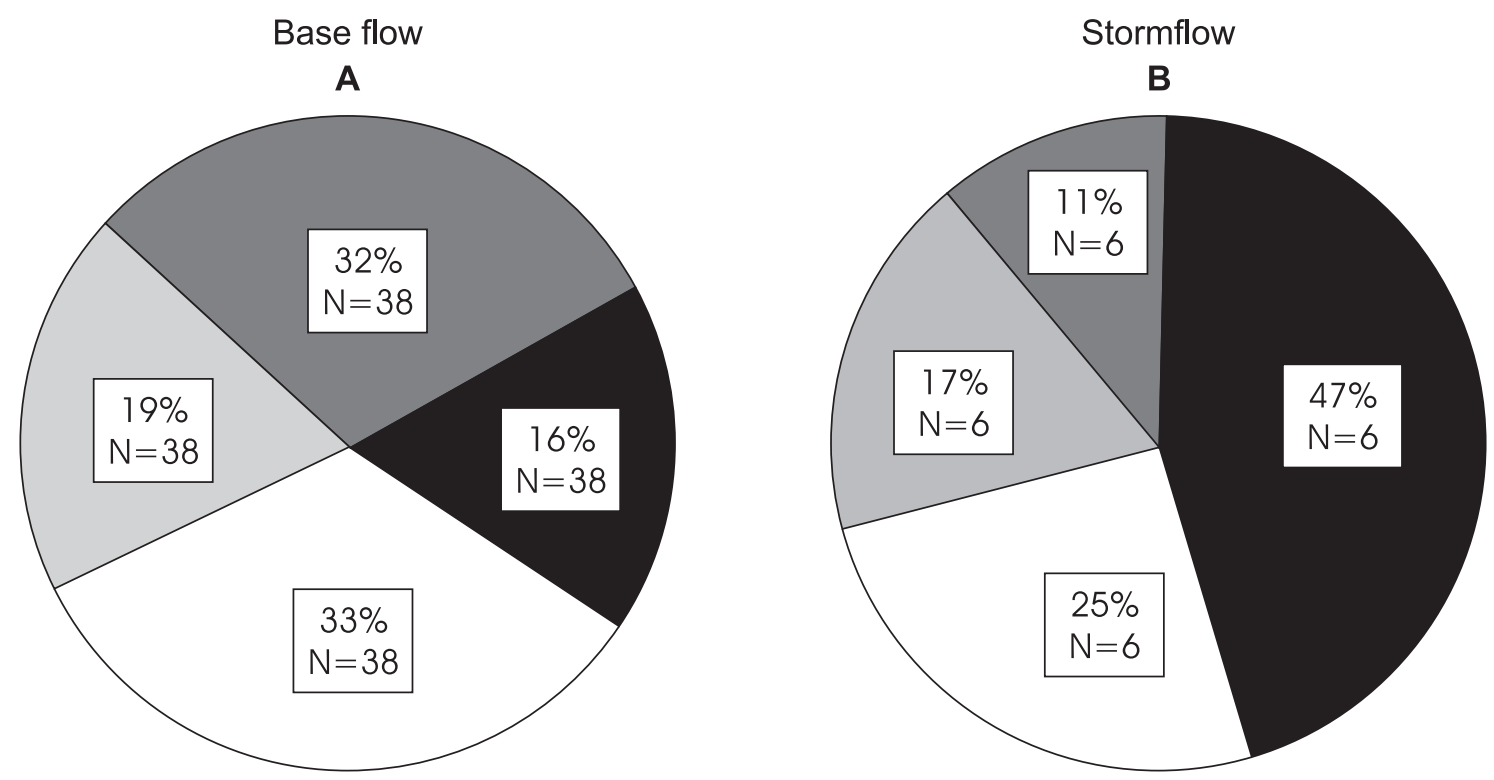

\section{EXPLANATION}

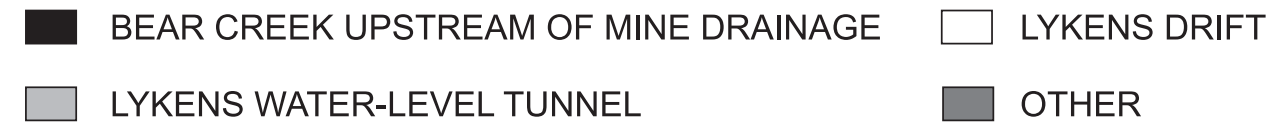

Figure 8. Percent contribution of base flow (A) and stormflow (B) to Bear Creek downstream of mine drainage (BC-DMD) computed as the mean ratio of instantaneous flow at sites Bear Creek upstream of mine drainage (BC-UMD), Lykens Water-Level Tunnel (LWLT), and Lykens Drift (LD) to instantaneous flow at site BC-DMD. Contribution from "Other" sources was computed as the difference between flow at BC-DMD and the sum of BC-UMD + LWLT + LD and expressed as a percent of flow at BC-DMD. "Other" sources include unmeasured mine drainage, ground water not originating from the Lykens-Williamstown Mine Pool, and surface-water runoff. "N" represents the number of times that instantaneous flow was determined for all sites under the specified flow condition. Note that the percent contribution from each site was not computed when flow data were unavailable for one or more of the sites. Thus, the number of computations in this figure is limited to 44 by site $\mathrm{BC}-\mathrm{UMD}$, which had the minimum number of flow determinations under any flow condition (38 base-flow determinations +6 stormflow determinations). Flow data were collected between March 1999 and December 2002. 


\section{Effects of Drainage From Abandoned Mines on Water Quality}

Water discharging from the Lykens-Williamstown Mine Pool is the transport medium that conveys the by-products of $\mathrm{FeS}_{2}$ oxidation (eqns. 1-5), and dissolution of (Fe, $\left.\mathrm{Mn}\right) \mathrm{CO}_{3}$ and aluminosilicate minerals to Bear Creek. Significant by-products that alter the water chemistry of Bear Creek include sulfate, iron, manganese, and aluminum. $\mathrm{ANC}$ (as $\mathrm{CaCO}_{3}$ ) is also an important constituent in mine water entering Bear Creek because it buffers protons $\left(\mathrm{H}^{+}\right.$ions) produced by hydrolysis reactions (eqns. 4 and 5). The principal contributors of abandoned mine drainage to Bear Creek are discharges at sites LWLT, LD, and diffuse zones of seepage. This section evaluates the combined effect of these discharges and seeps on the water quality of two sites on Bear Creek (BC-DMD and BCM) and the two sites on Wiconisco Creek (WC-UBC and WC-DBC).

Processes controlling the hydrology at sites LD and LWLT influence the chemistry of each discharge and the downstream reach of Bear Creek. Hydrologic and chemical data support at least two potential hydrologic processes that are responsible for chemical differences between discharges from LD and LWLT-(1) different underground flow paths through and residence times within the mine pool, and (2) surface runoff mixing with mine water during storm events.

Oxidation of $\mathrm{FeS}_{2}$ consumes oxygen and increases the concentration of iron (eqn. 2). In the presence of organic carbon and in the absence of oxygen, $\mathrm{Fe}(\mathrm{OH})_{3}$ reduction will occur in favor of sulfate reduction. Under these conditions, sulfate is reduced by a bacterially mediated reaction (eqn. 7) that produces hydrogen sulfide $\left(\mathrm{H}_{2} \mathrm{~S}\right)$ and ANC in the form of bicarbonate $\left(\mathrm{HCO}_{3}^{-}\right)$(Drever, 1988).

$$
\mathrm{SO}_{4}{ }^{2-}+2 \mathrm{CH}_{2} \mathrm{O}=\mathrm{H}_{2} \mathrm{~S}+2 \mathrm{HCO}_{3}^{-}
$$

Thus, the anoxic water with relatively high metals and ANC discharged from LD is characteristic of water that has a deep flow path through and long residence time within the mine pool. Sulfate reduction and the production of ANC by equation 7 does not occur if water has not been in contact with pyrite long enough to deplete nearly all dissolved oxygen. Therefore, the oxygenated, more acidic condition of water discharged from LWLT is characteristic of water that has a relatively short residence time within the mine pool.

The second process that creates chemical differences between LD and LWLT is the surface-water connection at LWLT during storm events (fig. 8). Precipitation in the eastern United States is more dilute than mine water entering Bear Creek (Hem, 1985, p. 35-36). During storm events, mine water discharging from LWLT is diluted by surface runoff. As a result, some chemical constituents are inversely correlated with flow. In contrast, the chemistry of water discharged from site LD is not correlated with flow because there is no surface-water connection.

\section{Net Acid Neutralizing Capacity (ANC)}

ANC is a measure of the capacity of solutes and particulate matter in water to neutralize acid. The principal source of ANC in mine water is dissolved carbonate, which can be in the form of bicarbonate ion $\left(\mathrm{HCO}_{3}{ }^{-}\right)$or carbonate ion $\left(\mathrm{CO}_{3}{ }^{2-}\right)$ (Hedin and others, 1994), depending on $\mathrm{pH}$. Dissolved carbonate may originate from water in contact with calcite in cementing materials of the Pottsville and Mauch Chunk Formations (Wood and others, 1986) and from bacterially mediated sulfate reduction (eqn. 7) (Drever, 1988). Bicarbonate is the predominant ionic form of carbonate in water with $\mathrm{pH}$ ranging from 5 to 8 (Stumm and Morgan, 1996); therefore, ANC in mine water entering Bear Creek is mainly from bicarbonate. Bicarbonate neutralizes free protons by the following reaction:

$$
\mathrm{H}^{+}+\mathrm{HCO}_{3}^{-}=\mathrm{H}_{2} \mathrm{O}+\mathrm{CO}_{2}
$$

Acidity is a measure of the base neutralization capacity of water and is primarily from three sources: (1) free protons (the concentration of $\left.\mathrm{H}^{+}\right)$, (2) carbonic acid $\left(\mathrm{H}_{2} \mathrm{CO}_{3}\right)$ and organic acidity from dissolved organic compounds, and (3) mineral acidity from dissolved iron (Fe), manganese ( $\mathrm{Mn})$, and aluminum (Al) (Hem, 1985, p. 111). Acidity from free protons increases with decreasing $\mathrm{pH}$. Proton acidity in mine drainage to Bear Creek is minimal because $\mathrm{pH}$ is relatively high (contribution of acidity from free protons calculated using the median $\mathrm{pH}$ at LWLT is only $0.06 \mathrm{mg} / \mathrm{L}$ as $\mathrm{CaCO}_{3}$ ). Dissolved metals contribute to acidity because they can undergo proton $\left(\mathrm{H}^{+}\right.$ion $)$ producing hydrolysis reactions like the one represented by equation 4. Because of elevated metal concentrations, mineral acidity is the largest source of acidity to Bear Creek.

Water can and commonly does contain both ANC and acidity. Net ANC was computed as ANC minus acidity as determined by the PaDEP laboratory. Negative values of net ANC represent net acidic conditions because there is not enough ANC to neutralize acidity. Positive values of net ANC indicate net alkaline conditions because there is more than enough ANC to neutralize acidity. Net ANC is an important design parameter for passive treatment because iron removal is slower in wetlands that receive net acidic mine water (Hedin and others, 1994).

Bear Creek upstream of mine drainage (BC-UMD) is net acidic, with a median net $\mathrm{ANC}$ of $-9.0 \mathrm{mg} / \mathrm{L}$ as $\mathrm{CaCO}_{3}$ (fig. 9, table 5$)^{2}$. All sources of acidity at site BC-UMD are not known, but contributors may include proton acidity from acidic precipitation, organic acids originating in the headwaters of Bear Creek, and dissolved iron and manganese. The water quality at this site can be characterized as relatively uninfluenced by mine drainage, although dissolved iron and manganese reached maximum concentrations of 7,090 and $850 \mu \mathrm{g} / \mathrm{L}$, respectively

\footnotetext{
${ }^{2}$ Water-quality data are published in Durlin and Schaffstall (2001, 2002, 2003) and are stored in the Water Quality (QWDATA) database of the National Water Information System (NWIS) (U.S. Geological Survey, 2005).
} 


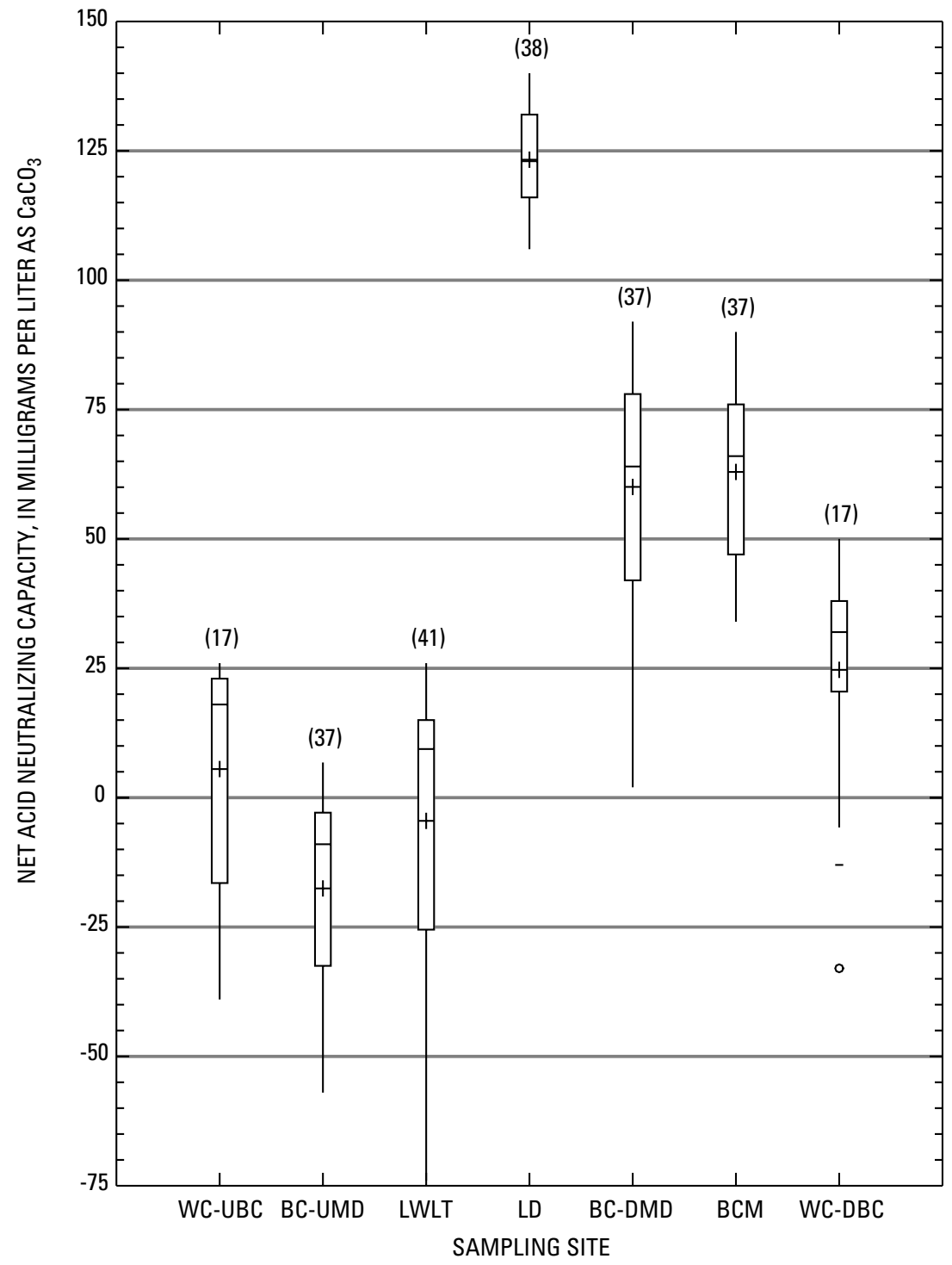

\section{EXPLANATION}

(10) Sample size

75th percentile plus 1.5 times the interquartile range or largest value, whichever is smaller.

75th percentile

+ Mean

Median (50th percentile)

25th percentile

25th percentile minus 1.5 times the interquartile range or the smallest value, whichever is smaller

- Outlier - point that is 1.5 to 3 times greater than the interquartile range

- Far outlier - point that is greater than three times the interquartile range

Figure 9. Ranges of net acid neutralizing capacity measured at seven sites in the Bear Creek study area, Dauphin County, Pennsylvania, from March 1999 to December 2002.

[WC-UBC, Wiconisco Creek upstream of Bear Creek; BC-UMD, Bear Creek upstream of mine drainage; LWLT, Lykens Water-Level Tunnel; LD, Lykens Drift; BC-DMD, Bear Creek downstream of mine drainage; BCM, Bear Creek at mouth; WC-DBC, Wiconisco Creek downstream of Bear Creek] 
Table 5. Summary statistics for water-quality data collected at nine sites on Bear Creek and two sites on Wiconisco Creek, Dauphin County, Pennsylvania, from March 1999 to December 2002.

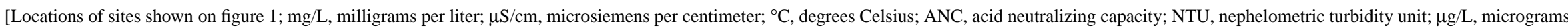
per liter; N, number of measurements; Max, maximum; Min, minimum; Stnd dev, standard deviation; P25, 25th percentile; P75, 75th percentile; \%, percent; <, less than; >, greater than; $\leq$, less than or equal to; $\geq$, greater than or equal to; -- not determined]

\begin{tabular}{|c|c|c|c|c|c|c|c|c|c|c|c|c|c|c|c|c|c|c|}
\hline Statistic & $\begin{array}{l}\text { Oxygen, } \\
\text { dis- } \\
\text { solved } \\
\text { (mg/L) }\end{array}$ & $\begin{array}{l}\text { Field } \\
\text { pH } \\
\text { (stan- } \\
\text { dard } \\
\text { units) }\end{array}$ & $\begin{array}{c}\text { Specific } \\
\text { conduc- } \\
\text { tance } \\
(\mu \mathrm{S} / \mathrm{cm})\end{array}$ & $\begin{array}{c}\text { Temper- } \\
\text { ature } \\
\left({ }^{\circ} \mathrm{C}\right)\end{array}$ & $\begin{array}{l}\text { Sodium, } \\
\text { total } \\
\text { (mg/L) }\end{array}$ & $\begin{array}{l}\text { Acidity, } \\
\text { heated, } \\
(\mathrm{mg} / \mathrm{L} \text { as } \\
\left.\mathrm{CaCO}_{3}\right)^{1}\end{array}$ & $\begin{array}{c}\text { Eh } \\
\text { (milli- } \\
\text { volts) }\end{array}$ & $\begin{array}{c}\mathrm{ANC}, \\
(\mathrm{mg} / \mathrm{L} \text { as } \\
\left.\mathrm{CaCO}_{3}\right)^{2}\end{array}$ & $\begin{array}{c}\text { Net } \\
\text { ANC, } \\
\text { (mg/L } \\
\text { as } \\
\left.\mathrm{CaCO}_{3}\right)^{3}\end{array}$ & $\begin{array}{c}\text { Sulfate, } \\
\text { dis- } \\
\text { solved } \\
\text { (mg/L) }\end{array}$ & $\begin{array}{c}\text { Residue, } \\
\text { total } \\
\text { sus- } \\
\text { pended } \\
\text { (mg/L) }\end{array}$ & $\begin{array}{l}\text { Turbid- } \\
\text { ity } \\
\text { (NTU) }\end{array}$ & $\begin{array}{l}\text { Alumi- } \\
\text { num, } \\
\text { total } \\
(\mu \mathrm{g} / \mathrm{L})\end{array}$ & $\begin{array}{l}\text { Iron, } \\
\text { dis- } \\
\text { solved } \\
(\mu \mathrm{g} / \mathrm{L})\end{array}$ & $\begin{array}{c}\begin{array}{c}\text { Iron, } \\
\text { ferrous, } \\
\text { field } \\
(\mu \mathrm{g} / \mathrm{L})\end{array}\end{array}$ & $\begin{array}{l}\text { Iron, } \\
\text { total } \\
(\mu \mathrm{g} / \mathrm{L})\end{array}$ & $\begin{array}{c}\text { Manga- } \\
\text { nese, } \\
\text { dis- } \\
\text { solved } \\
(\mu \mathrm{g} / \mathrm{L})\end{array}$ & $\begin{array}{c}\text { Manga- } \\
\text { nese, } \\
\text { total } \\
(\mu \mathrm{g} / \mathrm{L})\end{array}$ \\
\hline & \multicolumn{18}{|c|}{ Wiconisco Creek upstream of Bear Creek (WC-UBC) } \\
\hline $\mathrm{N}$ & 18 & 18 & 18 & 18 & 18 & 18 & -- & 17 & 17 & 18 & 18 & -- & 18 & 18 & 18 & 18 & 18 & 18 \\
\hline Max & 11.6 & 7.1 & 267 & 21.6 & 18.8 & 52 & -- & 30 & 26 & 73.8 & 92 & -- & 1,600 & 170 & 500 & 4,370 & 520 & 550 \\
\hline Min & 6.1 & 6.2 & 111 & 1.6 & 4.9 & .0 & -- & 13 & -39 & 21.9 & $<2$ & -- & $<200$ & 70 & $<500$ & 80 & 150 & 170 \\
\hline Mean & 7.8 & 6.7 & 188 & 12.5 & 8.2 & 14 & -- & 20 & 6 & 47.7 & -- & -- & -- & 110 & -- & 1,020 & 290 & 330 \\
\hline Median & 7.5 & 6.7 & 195 & 13.4 & 7.5 & .0 & -- & 20 & 18 & 46.1 & 16 & -- & 200 & 100 & $<500$ & 750 & 260 & 320 \\
\hline Stnd dev & 1.6 & .3 & 51 & 6.8 & 3.3 & 18 & -- & 5.0 & 22 & 15.2 & -- & -- & -- & 31 & -- & 950 & 110 & 120 \\
\hline P25 & 6.7 & 6.6 & 137 & 6.2 & 6.0 & .0 & -- & 16 & -16 & 35.9 & 4 & -- & $<200$ & 90 & $<500$ & 490 & 220 & 250 \\
\hline P75 & 8.8 & 7.0 & 229 & 19.1 & 9.5 & 32 & -- & 24 & 22 & 60.2 & 27 & -- & 650 & 130 & $<500$ & 1,350 & 370 & 390 \\
\hline \multirow[t]{2}{*}{$\%$ censored $^{4}$} & 0 & 0 & 0 & 0 & 0 & 0 & -- & 0 & 0 & 0 & 17 & -- & 42 & 0 & 89 & 0 & 0 & 0 \\
\hline & \multicolumn{18}{|c|}{ Bear Creek upstream of mine drainage (BC-UMD) } \\
\hline $\mathrm{N}$ & 41 & 43 & 43 & 42 & 39 & 38 & 22 & 37 & 37 & 41 & 38 & 15 & 39 & 42 & 41 & 42 & 42 & 39 \\
\hline Max & 14.6 & 6.1 & 98 & 17.5 & $\geq 1.1-10.0$ & 65 & 654 & 24 & 7 & 32.8 & 50 & 5.4 & 600 & 7,090 & 5,000 & 7,500 & 850 & 890 \\
\hline Min & .9 & 4.3 & 26 & .2 & $\leq .5$ & 1.4 & 216 & 3.0 & -57 & $\leq 10.6$ & $<2$ & .00 & $<200$ & $<20$ & $<500$ & $\leq 80$ & 120 & 100 \\
\hline Mean & 9.4 & 4.9 & 46 & 8.6 & -- & 26 & 405 & 8.5 & -18 & -- & -- & 1.3 & -- & -- & -- & -- & 360 & 370 \\
\hline Median & 10.0 & 4.6 & 40 & 9.8 & .6 & 24 & 428 & 7.0 & -9 & $<20.0$ & $<2$ & .9 & 300 & 410 & $<500$ & 550 & 270 & 300 \\
\hline Stnd dev & 3.7 & .5 & 17 & 5.2 & -- & 19 & 107 & 4.1 & 18 & -- & -- & 1.6 & -- & -- & -- & -- & 210 & 220 \\
\hline P25 & 8.6 & 4.5 & 36 & 3.8 & $<10.0$ & 9.1 & 374 & 7.0 & -31 & $<20.0$ & $<2$ & .00 & $<200$ & 140 & $<500$ & 190 & 200 & 200 \\
\hline P75 & 12.3 & 5.2 & 51 & 13.1 & $<10.0$ & 46 & 458 & 8.0 & -3 & $<20.0$ & 7 & 1.7 & 300 & 1,120 & $\leq 600$ & 1,230 & 500 & 540 \\
\hline \multirow[t]{2}{*}{$\%$ censored } & 0 & 0 & 0 & 0 & 5 & 0 & 0 & 0 & 0 & 76 & 58 & 0 & 23 & 2 & 73 & 5 & 0 & 0 \\
\hline & \multicolumn{18}{|c|}{ Lykens Water-Level Tunnel (LWLT) } \\
\hline $\mathrm{N}$ & 42 & 44 & 49 & 43 & 44 & 43 & 22 & 41 & 41 & 46 & 43 & 15 & 44 & 41 & 41 & 46 & 42 & 44 \\
\hline Max & 11.4 & 7.0 & 238 & 11.0 & $\geq 1.2-10.0$ & 74 & 630 & 32 & 26 & 82.3 & 224 & 150 & 1,000 & 11,900 & 6,000 & 15,800 & 1,200 & 1,200 \\
\hline Min & 6.5 & 5.1 & 96 & 8.0 & .6 & .0 & 243 & .0 & -74 & $<20.0$ & $<2$ & 22 & $<200$ & 910 & $<500$ & 4,410 & 630 & 640 \\
\hline Mean & 8.5 & 5.9 & 181 & 10.2 & -- & 21 & 352 & 16 & -4 & -- & -- & 92 & -- & 6,060 & -- & 10,500 & 923 & 920 \\
\hline Median & 8.5 & 5.9 & 179 & 10.3 & .8 & 7 & 335 & 16 & 9 & 63.0 & 12 & 99 & 300 & 5,170 & 2,100 & 10,000 & 889 & 890 \\
\hline Stnd dev & 1.0 & .3 & 26 & .5 & -- & 23 & 82 & 6.8 & 26 & -- & -- & 32 & -- & 3,000 & -- & 2,710 & 150 & 150 \\
\hline P25 & 8.2 & 5.8 & 165 & 10.0 & .7 & .0 & 311 & 14 & -24 & 53.8 & 4 & 86 & 200 & 3,620 & 1,000 & 8,780 & 810 & 800 \\
\hline P75 & 8.8 & 6.0 & 196 & 10.6 & .8 & 43 & 358 & 19 & 15 & 73.1 & 19 & 110 & 500 & 8,860 & 3,900 & 13,000 & 1,070 & 1,060 \\
\hline$\%$ censored & 0 & 0 & 0 & 0 & 5 & 0 & 0 & 0 & 0 & 4 & 12 & 0 & 18 & 0 & 5 & 0 & 0 & 0 \\
\hline
\end{tabular}


Table 5. Summary statistics for water-quality data collected at nine sites on Bear Creek and two sites on Wiconisco Creek, Dauphin County, Pennsylvania, from March 1999 to December 2002.-Continued

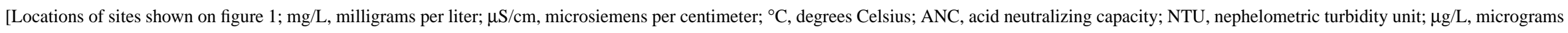
per liter; N, number of measurements; Max, maximum; Min, minimum; Stnd dev, standard deviation; P25, 25th percentile; P75, 75th percentile; \%, percent; <, less than; >, greater than; $\leq$, less than or equal to; $\geq$, greater than or equal to; -- not determined]

\begin{tabular}{|c|c|c|c|c|c|c|c|c|c|c|c|c|c|c|c|c|c|c|}
\hline Statistic & $\begin{array}{l}\text { Oxygen, } \\
\text { dis- } \\
\text { solved } \\
\text { (mg/L) }\end{array}$ & $\begin{array}{l}\text { Field } \\
\text { pH } \\
\text { (stan- } \\
\text { dard } \\
\text { units) }\end{array}$ & $\begin{array}{c}\text { Specific } \\
\text { conduc- } \\
\text { tance } \\
(\mu \mathrm{S} / \mathrm{cm})\end{array}$ & $\begin{array}{c}\text { Temper- } \\
\text { ature } \\
\left({ }^{\circ} \mathrm{C}\right)\end{array}$ & $\begin{array}{c}\text { Sodium, } \\
\text { total } \\
\text { (mg/L) }\end{array}$ & $\begin{array}{l}\text { Acidity, } \\
\text { heated, } \\
(\mathrm{mg} / \mathrm{L} \text { as } \\
\left.\mathrm{CaCO}_{3}\right)^{1}\end{array}$ & $\begin{array}{c}\text { Eh } \\
\text { (milli- } \\
\text { volts) }\end{array}$ & $\begin{array}{c}\text { ANC, } \\
(\mathrm{mg} / \mathrm{L} \text { as } \\
\left.\mathrm{CaCO}_{3}\right)^{2}\end{array}$ & $\begin{array}{c}\text { Net } \\
\text { ANC, } \\
(\mathrm{mg} / \mathrm{L} \\
\text { as } \\
\left.\mathrm{CaCO}_{3}\right)^{3}\end{array}$ & $\begin{array}{c}\text { Sulfate, } \\
\text { dis- } \\
\text { solved } \\
\text { (mg/L) }\end{array}$ & $\begin{array}{c}\text { Residue, } \\
\text { total } \\
\text { sus- } \\
\text { pended } \\
\text { (mg/L) }\end{array}$ & $\begin{array}{l}\text { Turbid- } \\
\text { ity } \\
\text { (NTU) }\end{array}$ & $\begin{array}{l}\text { Alumi- } \\
\text { num, } \\
\text { total } \\
(\mu \mathrm{g} / \mathrm{L})\end{array}$ & $\begin{array}{l}\text { Iron, } \\
\text { dis- } \\
\text { solved } \\
(\mu \mathrm{g} / \mathrm{L})\end{array}$ & $\begin{array}{c}\text { Iron, } \\
\text { ferrous, } \\
\text { field } \\
(\mu \mathrm{g} / \mathrm{L})\end{array}$ & $\begin{array}{c}\text { Iron, } \\
\text { total } \\
(\mu \mathrm{g} / \mathrm{L})\end{array}$ & $\begin{array}{c}\text { Manga- } \\
\text { nese, } \\
\text { dis- } \\
\text { solved } \\
(\mu \mathrm{g} / \mathrm{L})\end{array}$ & $\begin{array}{c}\text { Manga- } \\
\text { nese, } \\
\text { total } \\
(\mu \mathrm{g} / \mathrm{L})\end{array}$ \\
\hline & \multicolumn{18}{|c|}{ Lykens Drift (LD) } \\
\hline $\mathrm{N}$ & 42 & 44 & 44 & 43 & 39 & 38 & 21 & 38 & 38 & 41 & 38 & 14 & 39 & 42 & 41 & 42 & 42 & 39 \\
\hline Max & 5.7 & 7.1 & 370 & 13.4 & $\geq 6.6-10.0$ & .0 & 354 & 140 & 140 & 105 & 72 & 2.3 & $\geq 200-500$ & 21,400 & 19,000 & 23,000 & 2,490 & 2,490 \\
\hline Min & .2 & 6.1 & 282 & 11.3 & $\leq 4.4$ & .0 & 115 & 106 & 106 & 54.5 & $<2$ & .00 & $<200$ & 15,600 & 600 & 15,800 & 1,910 & 1,910 \\
\hline Mean & .8 & 6.5 & 346 & 13.2 & -- & .0 & 180 & 123 & 123 & 68.8 & -- & .40 & -- & 18,600 & 4,300 & 19,000 & 2,160 & 2,170 \\
\hline Median & .5 & 6.5 & 354 & 13.3 & $<10.0$ & .0 & 154 & 123 & 123 & 65.8 & 10 & .00 & $<200$ & 18,300 & 3,900 & 19,000 & 2,160 & 2,170 \\
\hline Stnd dev & 1.0 & .2 & 23 & .3 & -- & .0 & 64 & 8.4 & 8 & 11.0 & -- & .80 & -- & 1,200 & 3,290 & 1,380 & 110 & 100 \\
\hline P25 & .3 & 6.4 & 337 & 13.2 & $<10.0$ & .0 & 138 & 116 & 116 & 60.1 & 6 & .00 & $<200$ & 17,800 & 2,000 & 18,200 & 2,090 & 2,110 \\
\hline P75 & .8 & 6.6 & 364 & 13.3 & $<10.0$ & .0 & 187 & 132 & 132 & 76.0 & 19 & .20 & $<200$ & 19,500 & 4,800 & 19,700 & 2,220 & 2,230 \\
\hline \multirow[t]{2}{*}{$\%$ censored } & 0 & 0 & 0 & 0 & 5 & 0 & 0 & 0 & 0 & 0 & 8 & 0 & 97 & 0 & 0 & 0 & 0 & 0 \\
\hline & \multicolumn{18}{|c|}{ Bear Creek downstream of mine drainage (BC-DMD) } \\
\hline $\mathrm{N}$ & 43 & 45 & 45 & 44 & 39 & 38 & 22 & 37 & 37 & 41 & 38 & 15 & 39 & 42 & 40 & 42 & 42 & 39 \\
\hline Max & 11.9 & 7.1 & 324 & 14.6 & $\geq 5.2-10.0$ & 46 & 365 & 92 & 92 & 90.9 & 34 & 130 & $\geq 400-500$ & 14,100 & 8,800 & 20,100 & 2,020 & 2,050 \\
\hline Min & 7.0 & 6.2 & 103 & 6.5 & $\leq 1.9$ & .0 & 114 & 30 & 2 & 26.0 & $<2$ & 8.3 & $<200$ & 4,060 & $<500$ & 6,520 & 760 & 800 \\
\hline Mean & 9.4 & 6.8 & 235 & 11.3 & -- & 1.6 & 209 & 62 & 60 & 55.4 & -- & 31 & -- & 10,000 & -- & 12,300 & 1,480 & 1,480 \\
\hline Median & 9.4 & 6.8 & 234 & 11.6 & 3.2 & .0 & 191 & 64 & 64 & 57.7 & 20 & 25 & $<200$ & 9,970 & 3,300 & 12,600 & 1,540 & 1,480 \\
\hline Stnd dev & 1.2 & .2 & 55 & 2.3 & -- & 7.8 & 76 & 19 & 22 & 15.2 & -- & 29 & -- & 3,030 & -- & 3,210 & 390 & 400 \\
\hline P25 & 8.6 & 6.7 & 198 & 9.8 & 2.4 & .0 & 153 & 42 & 42 & 45.6 & 13 & 16 & $<200$ & 7,700 & 1,200 & 9,350 & 1,100 & 1,120 \\
\hline P75 & 10.2 & 6.9 & 285 & 13.3 & 3.8 & .0 & 249 & 78 & 78 & 63.0 & 24 & 29 & 200 & 12,900 & 4,100 & 14,800 & 1,800 & 1,780 \\
\hline \multirow[t]{2}{*}{$\%$ censored } & 0 & 0 & 0 & 0 & 5 & 0 & 0 & 0 & 0 & 0 & 5 & 0 & 72 & 0 & 3 & 0 & 0 & 0 \\
\hline & \multicolumn{18}{|c|}{ Bear Creek at mouth (BCM) } \\
\hline $\mathrm{N}$ & 41 & 43 & 43 & 42 & 39 & 38 & 22 & 37 & 37 & 41 & 38 & 15 & 39 & 42 & 41 & 42 & 42 & 39 \\
\hline Max & 12.0 & 7.8 & 299 & 17.2 & $\geq 6.5-10.0$ & .0 & 426 & 90 & 90 & 94.0 & 94 & 160 & 800 & 4,100 & 3,200 & 35,000 & 1,890 & 1,990 \\
\hline Min & 7.3 & 6.1 & 122 & 6.5 & 2.4 & .0 & 110 & 34 & 34 & $<20.0$ & $<2$ & 9.3 & $<200$ & 30 & $<500$ & 260 & 870 & 900 \\
\hline Mean & 9.9 & 7.1 & 231 & 11.8 & -- & .0 & 222 & 63 & 63 & -- & -- & 80 & -- & 1,580 & -- & 11,200 & 1,420 & 1,490 \\
\hline Median & 10.1 & 7.2 & 234 & 11.7 & $<10.0$ & .0 & 194 & 66 & 66 & 59.9 & 20 & 89 & $<200$ & 1,320 & $<500$ & 10,600 & 1,500 & 1,520 \\
\hline Stnd dev & 1.2 & .3 & 45 & 2.8 & -- & .0 & 79 & 16 & 16 & -- & -- & 39 & -- & 1,190 & -- & 5,590 & 300 & 330 \\
\hline P25 & 9.0 & 7.0 & 202 & 9.8 & $<10.0$ & .0 & 169 & 48 & 48 & 49.7 & 14 & 59 & $<200$ & 650 & $<500$ & 8,780 & 1,140 & 1,190 \\
\hline P75 & 10.8 & 7.4 & 267 & 14.4 & $<10.0$ & .0 & 242 & 76 & 76 & 65.9 & 30 & 96 & $<200$ & 2,490 & 1,300 & 12,700 & 1,660 & 1,760 \\
\hline$\%$ censored & 0 & 0 & 0 & 0 & 5 & 0 & 0 & 0 & 0 & 2 & 5 & 0 & 82 & 0 & 54 & 0 & 0 & 0 \\
\hline
\end{tabular}


Table 5. Summary statistics for water-quality data collected at nine sites on Bear Creek and two sites on Wiconisco Creek, Dauphin County, Pennsylvania, from March 1999

to December 2002.-Continued

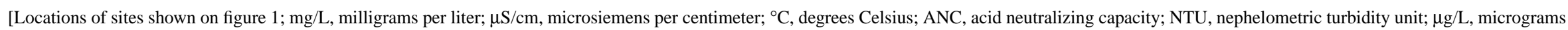
per liter; N, number of measurements; Max, maximum; Min, minimum; Stnd dev, standard deviation; P25, 25th percentile; P75, 75th percentile; \%, percent; <, less than; >, greater than; $\leq$, less than or equal to; $\geq$, greater than or equal to; -- not determined]

\begin{tabular}{|c|c|c|c|c|c|c|c|c|c|c|c|c|c|c|c|c|c|c|}
\hline Statistic & $\begin{array}{c}\text { Oxygen, } \\
\text { dis- } \\
\text { solved } \\
\text { (mg/L) }\end{array}$ & $\begin{array}{l}\text { Field } \\
\text { pH } \\
\text { (stan- } \\
\text { dard } \\
\text { units) }\end{array}$ & $\begin{array}{c}\text { Specific } \\
\text { conduc- } \\
\text { tance } \\
(\mu \mathrm{S} / \mathrm{cm})\end{array}$ & $\begin{array}{c}\text { Temper- } \\
\text { ature } \\
\left({ }^{\circ} \mathrm{C}\right)\end{array}$ & $\begin{array}{l}\text { Sodium, } \\
\text { total } \\
\text { (mg/L) }\end{array}$ & $\begin{array}{l}\text { Acidity, } \\
\text { heated, } \\
(\mathrm{mg} / \mathrm{L} \text { as } \\
\left.\mathrm{CaCO}_{3}\right)^{1}\end{array}$ & $\begin{array}{c}\text { Eh } \\
\text { (milli- } \\
\text { volts) }\end{array}$ & $\begin{array}{c}\text { ANC, } \\
(\mathrm{mg} / \mathrm{L} \text { as } \\
\left.\mathrm{CaCO}_{3}\right)^{2}\end{array}$ & $\begin{array}{c}\text { Net } \\
\text { ANC, } \\
(\mathrm{mg} / \mathrm{L} \\
\text { as } \\
\left.\mathrm{CaCO}_{3}\right)^{3}\end{array}$ & $\begin{array}{c}\text { Sulfate, } \\
\text { dis- } \\
\text { solved } \\
\text { (mg/L) }\end{array}$ & $\begin{array}{c}\text { Residue, } \\
\text { total } \\
\text { sus- } \\
\text { pended } \\
\text { (mg/L) }\end{array}$ & $\begin{array}{c}\text { Turbid- } \\
\text { ity } \\
\text { (NTU) }\end{array}$ & $\begin{array}{l}\text { Alumi- } \\
\text { num, } \\
\text { total } \\
(\mu \mathrm{g} / \mathrm{L})\end{array}$ & $\begin{array}{l}\text { Iron, } \\
\text { dis- } \\
\text { solved } \\
(\mu \mathrm{g} / \mathrm{L})\end{array}$ & $\begin{array}{c}\begin{array}{c}\text { Iron, } \\
\text { ferrous, } \\
\text { field } \\
(\mu \mathrm{g} / \mathrm{L})\end{array}\end{array}$ & $\begin{array}{l}\text { Iron, } \\
\text { total } \\
(\mu \mathrm{g} / \mathrm{L})\end{array}$ & $\begin{array}{c}\text { Manga- } \\
\text { nese, } \\
\text { dis- } \\
\text { solved } \\
(\mu \mathrm{g} / \mathrm{L})\end{array}$ & $\begin{array}{c}\text { Manga- } \\
\text { nese, } \\
\text { total } \\
(\mu \mathrm{g} / \mathrm{L})\end{array}$ \\
\hline & \multicolumn{18}{|c|}{ Wiconisco Creek downstream of Bear Creek (WC-DBC) } \\
\hline $\mathrm{N}$ & 18 & 18 & 18 & 18 & 18 & 18 & 3 & 17 & 17 & 18 & 18 & -- & 18 & 18 & 17 & 18 & 18 & 17 \\
\hline Max & 11.5 & 7.3 & 293 & 19.8 & 10.1 & 49 & 300 & 50 & 50 & 73.7 & 182 & -- & 1,600 & 680 & 1,000 & 7,330 & 980 & 1,050 \\
\hline Min & 6.8 & 6.1 & 113 & 2.2 & .8 & .0 & 210 & 16 & -33 & 23.1 & $<2$ & -- & $<200$ & 80 & $<500$ & 130 & 300 & 350 \\
\hline Mean & 8.3 & 6.8 & 202 & 12.1 & 6.4 & 6.1 & 252 & 31 & 25 & 49.6 & -- & -- & -- & 320 & -- & 3,610 & 590 & 660 \\
\hline Median & 7.9 & 6.9 & 205 & 13.3 & 6.6 & .0 & 245 & 32 & 32 & 51.5 & 20 & -- & $<200$ & 330 & $<500$ & 3,490 & 550 & 640 \\
\hline Stnd dev & 1.2 & .4 & 57 & 5.8 & 2.1 & 14 & 45 & 10 & 22 & 14.0 & -- & -- & -- & 160 & -- & 2,110 & 200 & 200 \\
\hline P25 & 7.6 & 6.5 & 148 & 6.8 & 5.2 & .0 & 228 & 22 & 21 & 41.6 & 3 & -- & $<200$ & 220 & $<500$ & 2,120 & 460 & 560 \\
\hline P75 & 9.1 & 7.0 & 249 & 17.3 & 7.5 & .0 & 273 & 36 & 36 & 59.6 & 26 & -- & 450 & 360 & $<500$ & 4,710 & 710 & 730 \\
\hline$\%$ censored & 0 & 0 & 0 & 0 & 0 & 0 & 0 & 0 & 0 & 0 & 17 & -- & 50 & 0 & 76 & 0 & 0 & 0 \\
\hline
\end{tabular}

${ }^{1}$ Acidity, as determined by the Pennsylvania Department of Environmental Protection Laboratory and reported as positive values or zero. If the pH of the sample was 6.5 , a zero value for acidity was reported. No negative values were reported.

${ }^{2}$ Determined by titration to an endpoint $\mathrm{pH}$ of 3.9 .

${ }^{3}$ Computed as ANC minus acidity as determined by the Pennsylvania Department of Environmental Protection.

${ }^{4}$ Censored refers to values preceded by a less-than sign (<). 
(table 5). Concentrations of dissolved iron and manganese above the median values (410 and $270 \mu \mathrm{g} / \mathrm{L}$, respectively) generally were at low flow, when site BC-UMD was dominated by stagnant pools. Because dissolved metals concentrations increased at low flow, the lowest net ANC also was at low flow (fig. 10).

Net ANC at site LWLT ranged from -74 to $26 \mathrm{mg} / \mathrm{L}$ as $\mathrm{CaCO}_{3}$; the median was $9 \mathrm{mg} / \mathrm{L}$ as $\mathrm{CaCO}_{3}$ (fig. 9). The lowest net ANC values were during low flow (fig. 10) and were concurrent with the highest dissolved iron and manganese concentrations. The discharge at site LD was the largest source of ANC to Bear Creek with a median of $123 \mathrm{mg} / \mathrm{L}$ as $\mathrm{CaCO}_{3}$ (fig. 9) and varied little with flow (fig. 10). Net ANC in water from site LD was significantly higher than the discharge at site LWLT ( $\mathrm{p}$-value $=<.0001$; table 6 ). Because of the odor of $\mathrm{H}_{2} \mathrm{~S}$ at site $\mathrm{LD}$, the source of ANC is probably sulfate reduction (eqn. 7). Relatively high ANC and reducing conditions of site LD compared to LWLT suggest that water discharging from site LD has a longer residence time in the mine pool than water discharging at site LWLT. Mixing of water from LWLT, LD, and diffuse seeps with the net acidic waters of BC-UMD resulted in an increase in the median net ANC at site BC-DMD to $64 \mathrm{mg} / \mathrm{L}$ as $\mathrm{CaCO}_{3}$ (fig. 9). Little change in net ANC occurred between BC-DMD and BCM (table 6). The overall effect of Bear Creek mixing with Wiconisco Creek was an increase in median net ANC of $14 \mathrm{mg} / \mathrm{L}$ as $\mathrm{CaCO}_{3}$ at site WC-DBC compared to WC-UBC (table 5) (p-value $=0.0005$; table 6).

\section{Specific Conductance}

Specific conductance is a measure of the capacity of dissolved ions in water to conduct an electrical current (Wilde and others, 1998). Specific conductance is related to the dissolved solids concentration (Hem, 1985, p. 67) and can be used as a qualitative measure to distinguish between waters with high and low concentrations of dissolved solids. The major ions responsible for elevated specific conductance in Bear Creek are $\mathrm{SO}_{4}{ }^{2-}, \mathrm{HCO}_{3}{ }^{-}, \mathrm{Fe}^{2+}, \mathrm{Fe}^{3+}$, and $\mathrm{Mn}^{2+}$.
Site BC-UMD had water with low specific conductance (fig. 11) because of the relative absence of mine drainage compared to downstream sites. Specific conductance in water at site BC-UMD ranged from 26 to $98 \mu \mathrm{S} / \mathrm{cm}$; the median was $40 \mu \mathrm{S} / \mathrm{cm}$ (table 5). There was little correlation with flow, although the specific conductance values were highest at very low flow when dissolved solids were concentrated in stagnant pools by evaporation (fig. 12). The range of specific conductance values at site BC-UMD was comparable to nearby unmined watersheds that supply water to the town of Lykens (Charles McGarrell, Pennsylvania Department of Environmental Protection, oral commun., 2000).

Median specific conductance of water discharging at LWLT was $179 \mu \mathrm{S} / \mathrm{cm}$ (table 5) and decreased as flow increased (fig. 12). The relation of decreasing specific conductance with flow was evidence of a connection to unimpacted water, either by runoff entering between the LWLT outlet and the sampling location $200 \mathrm{ft}$ downstream or precipitation infiltrating into the local underground mine water that drains to site LWLT. In contrast, specific conductance of water discharging from LD varied little with flow, indicating a poor surface-water connection (fig. 12). Median specific conductance of water at site LD was $354 \mu \mathrm{S} / \mathrm{cm}$ (table 5), significantly higher than at site LWLT (p-value $=<0.0001$; table 6). Specific conductance in water at BC-DMD ranged from 103 to $324 \mu \mathrm{S} / \mathrm{cm}$; the median was $234 \mu \mathrm{S} / \mathrm{cm}$ (table 5), a significant increase compared to BC-UMD (p-value $=<0.0001$; table 6 ). As at site LWLT, specific conductance decreased at sites BC-DMD and $\mathrm{BCM}$ as flow increased (fig. 12). This was the result of an increase in the proportion of relatively dilute runoff originating in the headwaters during storm events (fig. 8). Bear Creek increased the median specific conductance at site WC-DBC by $10 \mu \mathrm{S} / \mathrm{cm}$ compared to site WC-UBC (table 5) $(\mathrm{p}$-value $=$ 0.0014; table 6). 
FLOW, IN CUBIC FEET PER SECOND
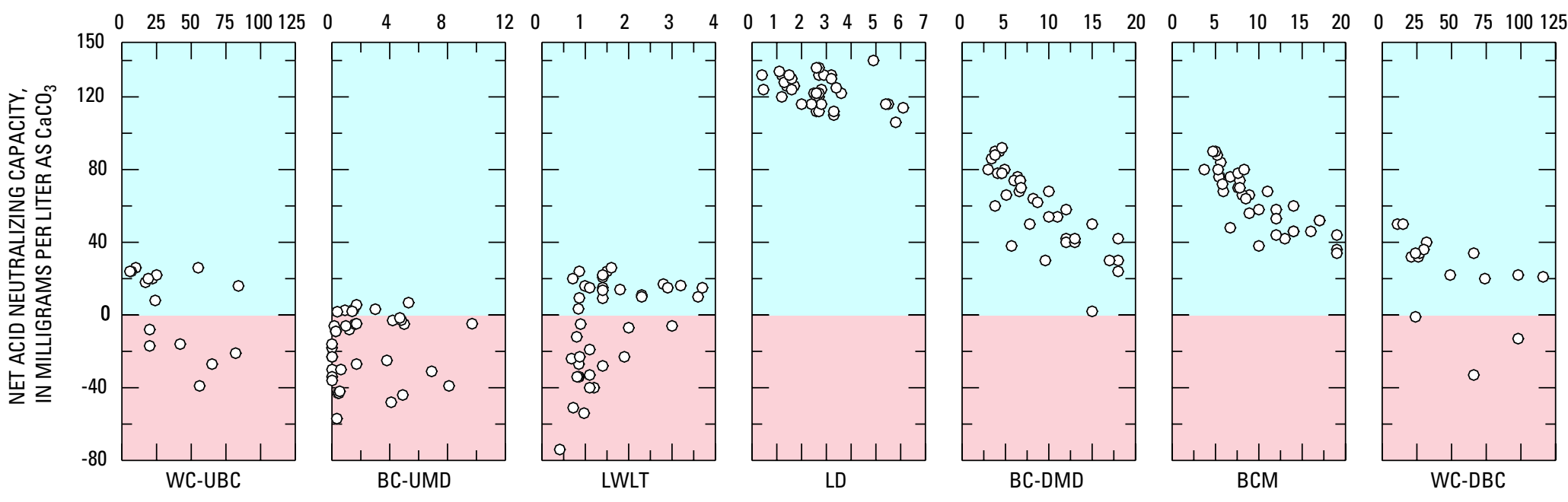

SAMPLING SITE

EXPLANATION

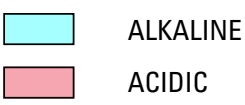

Figure 10. Relation of net acid neutralizing capacity to flow at seven sites in the Bear Creek study area, Dauphin County, Pennsylvania, from March 1999 to December 2002.

[WC-UBC, Wiconisco Creek upstream of Bear Creek; BC-UMD, Bear Creek upstream of mine drainage; LWLT, Lykens Water-Level Tunnel; LD, Lykens Drift; BC-DMD, Bear Creek downstream of mine drainage; BCM, Bear Creek at mouth; WC-DBC, Wiconisco Creek downstream of Bear Creek] 
Table 6. Results of statistical analyses performed on four paired sites in the Bear Creek study area, Dauphin County, Pennsylvania.

[Locations of sites shown on figure 1; WC-UBC, Wiconisco Creek upstream of Bear Creek; BC-UMD, Bear Creek upstream of mine drainage; LWLT, Lykens Water-Level Tunnel; LD, Lykens Drift; BC-DMD, Bear Creek downstream of mine drainage; BCM, Bear Creek at mouth; WC-DBC, Wiconisco Creek downstream of Bear Creek; mg/L, milligrams per liter; $\mu \mathrm{S} / \mathrm{cm}$, microsiemens per centimeter; ${ }^{\circ} \mathrm{C}$, degrees Celsius; $\mathrm{mV}$, millivolts; ANC, acid neutralizing capacity; NTU, nephelometric turbidity unit; $\mu \mathrm{g} / \mathrm{L}$ micrograms per liter; <, less than; --, not determined]

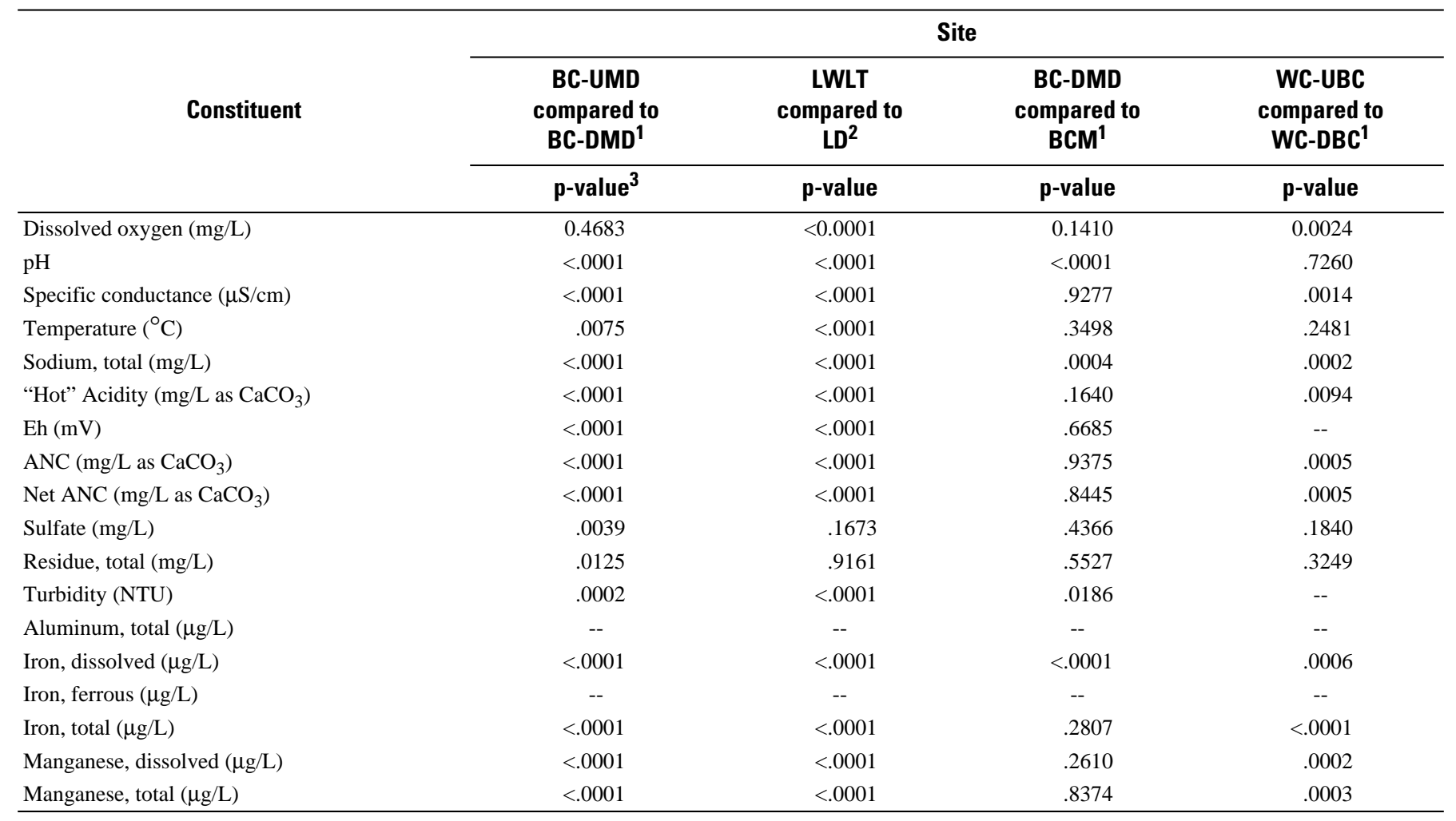

${ }^{1}$ Results of two-sided Wilcoxon signed-rank test.

${ }^{2}$ Results of two-sided Wilcoxon rank-sum test.

${ }^{3}$ For this study, the null hypothesis is rejected if the p-value is less than 0.05 . 


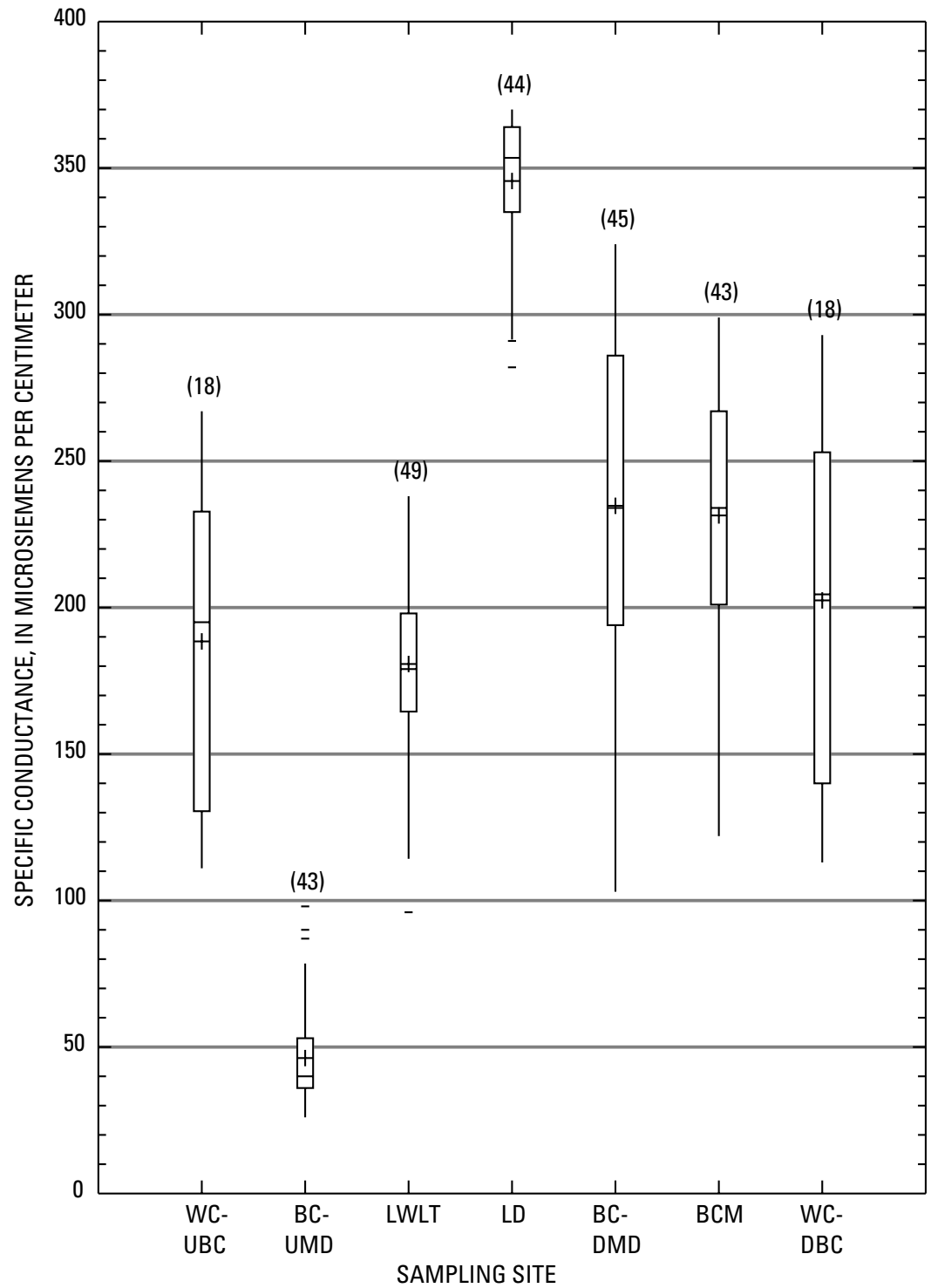

(18) Sample size

75th percentile plus 1.5 times the interquartile range or largest value, whichever is smaller

75th percentile

Mean

Median (50th percentile)

25th percentile

25th percentile minus 1.5 times the interquartile range or the smallest value, whichever is smaller

- Outlier - point that is 1.5 to

3 times greater than the interquartile range

Figure 11. Ranges of specific conductance measured at seven sites in the Bear Creek study area, Dauphin County, Pennsylvania, from March 1999 to December 2002.

[WC-UBC, Wiconisco Creek upstream of Bear Creek; BC-UMD, Bear Creek upstream of mine drainage; LWLT, Lykens WaterLevel Tunnel; LD, Lykens Drift; BC-DMD, Bear Creek downstream of mine drainage; BCM, Bear Creek at mouth; WC-DBC, Wiconisco Creek downstream of Bear Creek] 
FLOW, IN CUBIC FEET PER SECOND

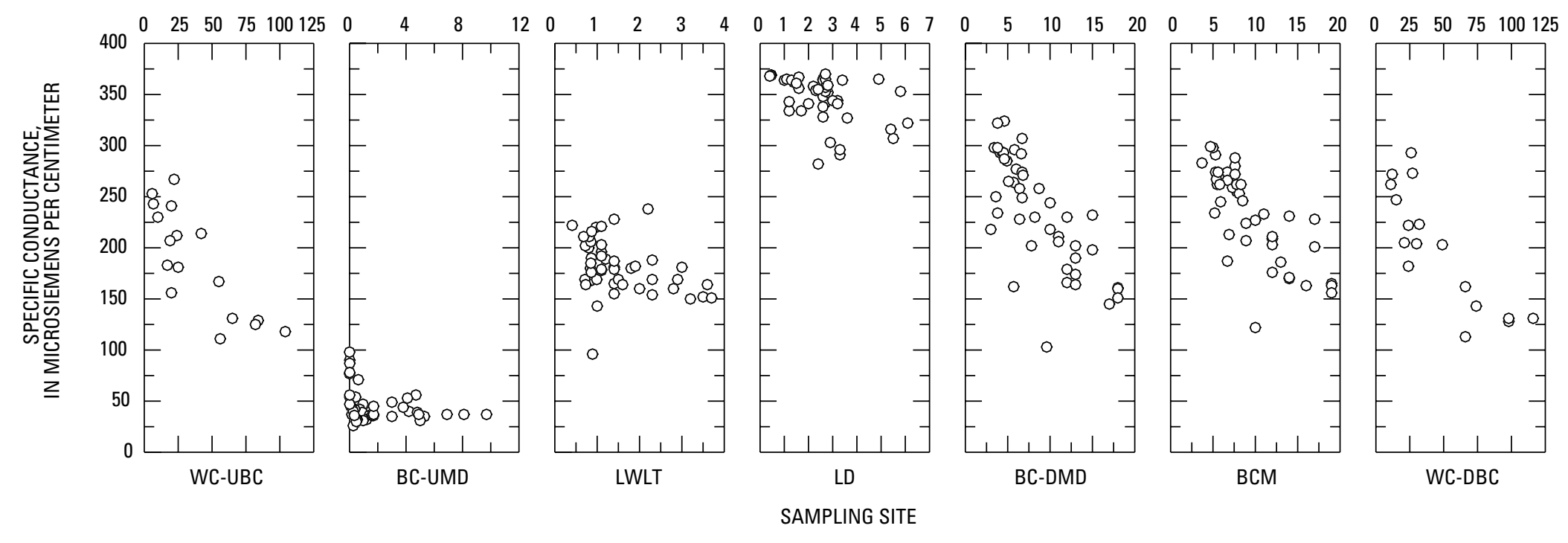

Figure 12. Relation of specific conductance to flow at seven sites in the Bear Creek study area, Dauphin County, Pennsylvania, from March 1999 to December 2002.

[WC-UBC, Wiconisco Creek upstream of Bear Creek; BC-UMD, Bear Creek upstream of mine drainage; LWLT, Lykens Water-Level Tunnel; LD, Lykens Drift; BC-DMD, Bear Creek downstream of mine drainage; BCM, Bear Creek at mouth; WC-DBC, Wiconisco Creek downstream of Bear Creek] 


\section{Effects of Coal Mining and Drainage From Abandoned Mines on Streamflow and Water Quality, Bear Creek, 1999-2002}

\section{Dissolved Oxygen}

Dissolved oxygen is an important constituent for the removal of iron because it is the oxidizing agent in the hydrolysis reactions that produce solid iron precipitates, nominally $\mathrm{Fe}(\mathrm{OH})_{3}$ (eqn. 4). The solubility of oxygen in water is limited by and is directly proportional to its partial pressure in air and water temperature. The water discharging from LWLT differed from water discharging from LD with respect to oxygen concentration; thus, treatment approaches for iron removal will need to consider these differences.

Streamwater at BC-UMD was aerobic except when streamflow was $<0.01 \mathrm{ft}^{3} / \mathrm{s}$. Median dissolved oxygen concentration over the range of measured flows was $10.0 \mathrm{mg} / \mathrm{L}$ (fig. 13, table 5). When flow was $<0.01 \mathrm{ft}^{3} / \mathrm{s}$, median dissolved oxygen concentration was only $2.3 \mathrm{mg} / \mathrm{L}$, reaching a minimum of $0.9 \mathrm{mg} / \mathrm{L}$ (fig. 14). This could have been a result of biological oxygen demand from organic matter that was not transported because of stagnant flow. Higher concentration of metals at low flow also may contribute to oxygen depletion because oxygen is necessary for hydrolysis of dissolved metals.

The discharge from LWLT was aerobic over the entire range of flow conditions; the median dissolved oxygen concentration was $8.5 \mathrm{mg} / \mathrm{L}$ (table 5). In contrast, LD was nearly anoxic (figs. 13 and 14); the median dissolved oxygen concentration was $0.5 \mathrm{mg} / \mathrm{L}$ (table 5). The odor of hydrogen sulfide gas $\left(\mathrm{H}_{2} \mathrm{~S}\right)$ emanated from water discharged at LD providing evidence that pyrite oxidation (eqn. 1) had consumed nearly all oxygen and sulfate reduction (eqn. 7) was occurring. Although water draining from LD was anoxic at the point of discharge, oxygenation occurred quickly. Dissolved oxygen concentration was nearly 75 percent saturation only $50 \mathrm{ft}$ downstream of the source (Jeffrey Chaplin, U.S. Geological Survey, 2000, unpub. data). This was a result of exposure to air that was facilitated by turbulent flow over the steep gradient between site LD and its confluence with Bear Creek (a decrease in elevation of approximately $20 \mathrm{ft}$ over a horizontal distance of $100 \mathrm{ft}$ ). Despite rapid oxygenation, oxidation of iron was incomplete.

As a result of oxygenation between site LD and Bear Creek, dissolved oxygen at site BC-DMD remained relatively high; the median was $9.4 \mathrm{mg} / \mathrm{L}$ (table 5). The range of dissolved oxygen concentrations measured at site BC-DMD was smaller than at site BC-UMD because inputs from LWLT and LD varied less (fig. 13) and showed no relation to flow (fig. 14). Mine drainage did not significantly change dissolved oxygen concentration between sites BC-UMD and BC-DMD (p-value = 0.4683; table 6). Median dissolved oxygen increased slightly to $10.1 \mathrm{mg} / \mathrm{L}$ at site BCM (table 5), but the increase was not statistically significant ( $p$-value $=0.1410$; table 6 ). The net effect of Bear Creek on Wiconisco Creek was an increase in median dissolved oxygen of $0.4 \mathrm{mg} / \mathrm{L}$ at site WC-DBC (table 5). Even though this increase was statistically significant $(\mathrm{p}$-value $=$ 0.0024; table 6), it is negligible from a biological or treatment perspective.
pH

The $\mathrm{pH}$ of water is the negative log of hydrogen ion concentration and ranges from 6.5 to 8.5 in most natural streams (Hem, 1985). Abandoned mine drainage can be acidic $(\mathrm{pH}<7.0)$ or alkaline ( $\mathrm{pH}>7.0)$, but $\mathrm{pH}$ alone is misleading because of mineral acidity in the form of dissolved metals. Water that has near-neutral $\mathrm{pH}$ and elevated concentrations of dissolved metals (particularly dissolved iron) has the potential to become acidic after oxidation and hydrolysis of the metals (eqns. 3 and 4, respectively). This potential is measured by acidity titration, not $\mathrm{pH}$. Hence, acidity is a more useful measurement to characterize the severity of mine drainage (Rose and Cravotta, 1998).

Nonetheless, $\mathrm{pH}$ is an important consideration for iron removal because low $\mathrm{pH}$ increases the solubility of metal hydroxides and negatively influences the rate of the oxidation and hydrolysis processes important to iron removal in passive-treatment systems (Hedin and others, 1994).

Bear Creek is poorly buffered (median net $\mathrm{ANC}=$ $-9.0 \mathrm{mg} / \mathrm{L}$ as $\mathrm{CaCO}_{3}$; table 5) upstream of the mine discharges (BC-UMD) and has a median $\mathrm{pH}$ of 4.6 (fig. 15). Because buffer capacity is low, $\mathrm{pH}$ is subject to change upon the introduction of acidity or alkalinity. Acidity can be derived from dilute weakly acidic rainfall that may become more acidic upon contact with unconsolidated coal spoil. When storm runoff mixed with streamwater above BC-UMD, any ANC was quickly depleted and the $\mathrm{pH}$ decreased, resulting in the inverse correlation between streamflow and $\mathrm{pH}$ depicted in figure 16 . The highest $\mathrm{pH}$ values at $\mathrm{BC}-\mathrm{UMD}$ were measured under very low flow conditions (fig. 16) dominated by stagnant pools.

ANC in water discharged from sites LWLT, LD, and diffuse zones of seepage buffered the net acidic headwaters upon mixing. The median $\mathrm{pH}$ of site LWLT was 5.9 (table 5) and was poorly correlated with flow (fig. 16) despite a connection with weakly acidic surface runoff discussed earlier in this report.

Water discharged from LWLT is commonly net alkaline at high flows (fig. 10), indicating that $\mathrm{pH}$ is least likely to change when mixing with surface runoff is greatest. Water discharging from LD was near neutral (median $\mathrm{pH}=6.5$; fig. 15) and was not correlated with flow (fig. 16). Low variability of $\mathrm{pH}$ over the range of measured flow conditions at LD (standard deviation $=0.2 \mathrm{pH}$ units; table 5) suggests that excess ANC (fig. 9) derived from sulfate reduction (eqn. 7) or prolonged contact with carbonate cementing media in the Mauch Chunk and Pottsville Formations (figs. 2 and 3) buffers any acidity production. Water discharged from LD buffers and stabilizes the $\mathrm{pH}$ at site BC-DMD over the range of measured streamflows (fig. 16). However, the inverse relation between $\mathrm{pH}$ and flow at site BCM (fig. 16) indicates that ANC from LD was not great enough to buffer all acidic surface runoff between sites BC-DMD and BCM.

The chemistry of streamwater at site BC-DMD represents a mixture of two main source waters - the weakly acidic headwaters and the comparatively alkaline mine discharges. ANC in mine drainage from LD and associated seeps increased 


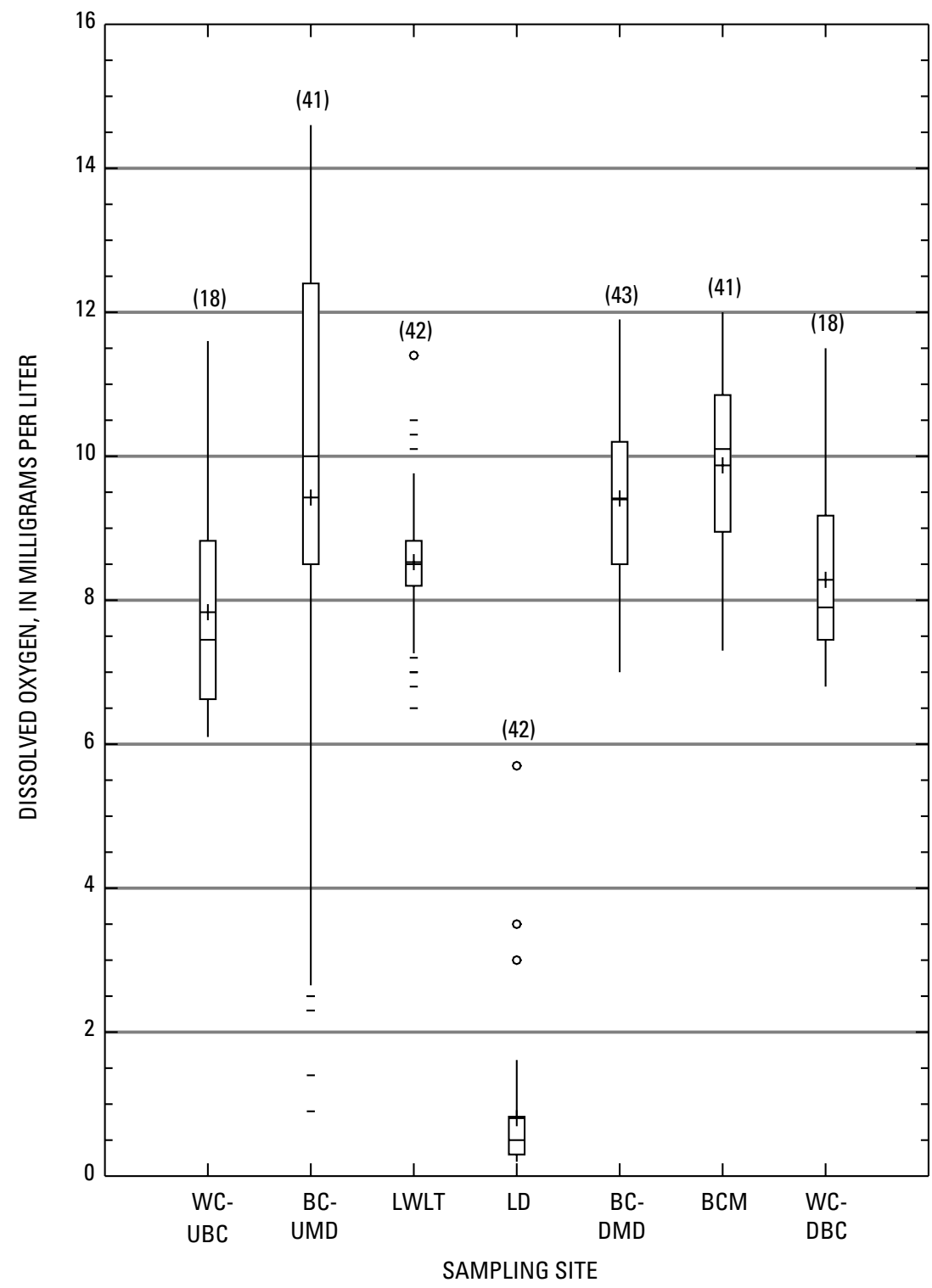

\section{EXPLANATION}

(18) Sample size

75th percentile plus 1.5 times the interquartile range or largest value, whichever is smaller

75th percentile

+ Mean

Median (50th percentile)

25th percentile

25th percentile minus 1.5 times the interquartile range or the smallest value, whichever is smaller

- Outlier - point that is 1.5 to

3 times greater than the interquartile range

- Far outlier - point that is greater than 3 times the interquartile range

Figure 13. Ranges of dissolved oxygen measured at seven sites in the Bear Creek study area, Dauphin County, Pennsylvania, from March 1999 to December 2002.

[WC-UBC, Wiconisco Creek upstream of Bear Creek; BC-UMD, Bear Creek upstream of mine drainage; LWLT, Lykens Water-Level Tunnel; LD, Lykens Drift; BC-DMD, Bear Creek downstream of mine drainage; BCM, Bear Creek at mouth; WC-DBC, Wiconisco Creek downstream of Bear Creek] 


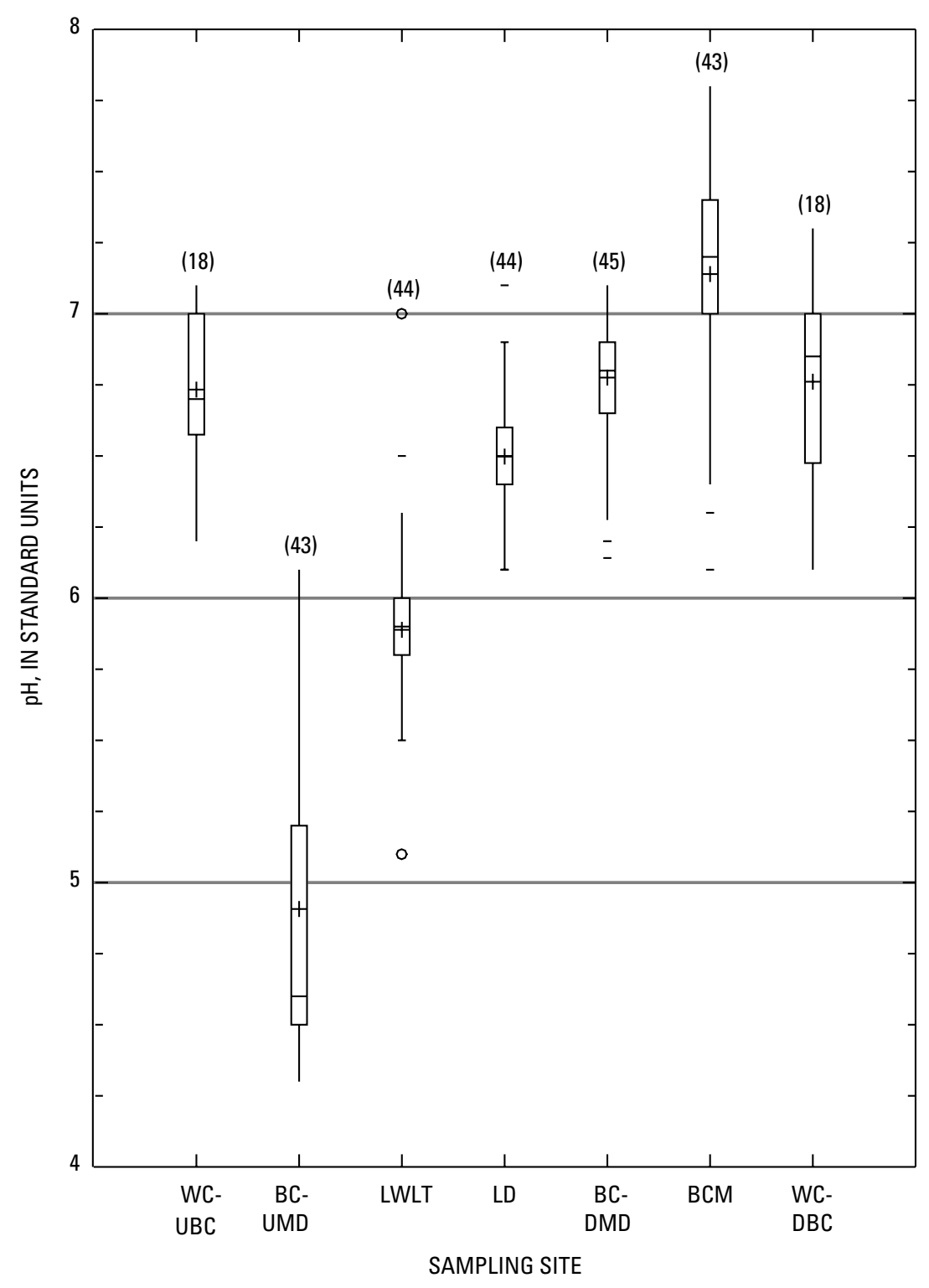

EXPLANATION

(10) Sample size

75th percentile plus 1.5 times the interquartile range or largest value, whichever is smaller.

75th percentile

+ Mean

Median (50th percentile)

25th percentile

25th percentile minus 1.5 times the interquartile range or the smallest value, whichever is smaller

- Outlier - point that is 1.5 to 3 times greater than the interquartile range

- Far outlier - point that is greater than

3 times the interquartile range

Figure 15. Ranges of pH measured at seven sites in the Bear Creek study area, Dauphin County, Pennsylvania, from March 1999 to December 2002.

[WC-UBC, Wiconisco Creek upstream of Bear Creek; BC-UMD, Bear Creek upstream of mine drainage; LWLT, Lykens WaterLevel Tunnel; LD, Lykens Drift; BC-DMD, Bear Creek downstream of mine drainage; BCM, Bear Creek at mouth; WC-DBC, Wiconisco Creek downstream of Bear Creek] 
FLOW, IN CUBIC FEET PER SECOND
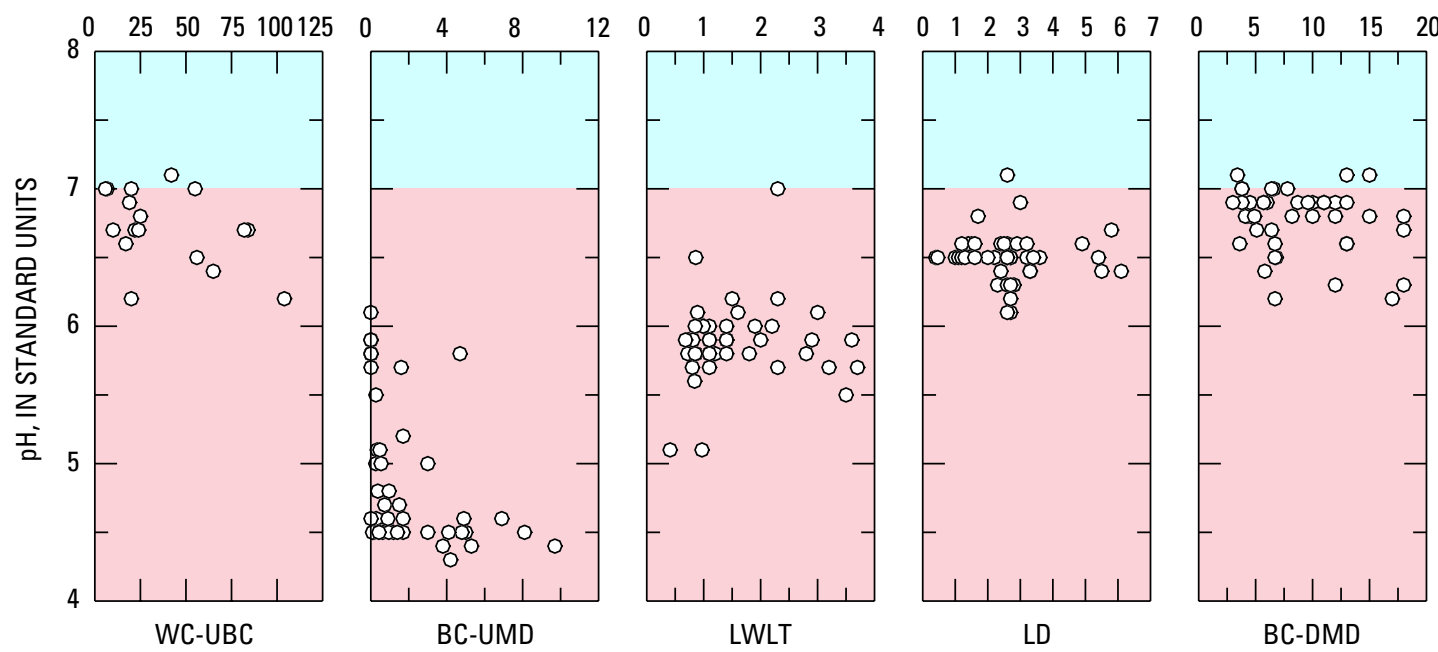

BC-DMD

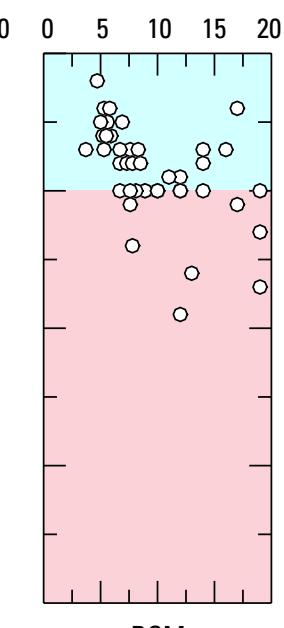

BCM

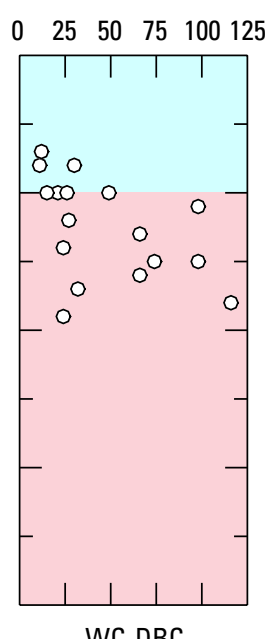

SAMPLING SITE

WC-DBC

\section{EXPLANATION}

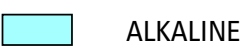

ACIDIC

Figure 16. Relation of pH to flow at seven sites in the Bear Creek study area, Dauphin County, Pennsylvania, from March 1999 to December 2002.

[WC-UBC, Wiconisco Creek upstream of Bear Creek; BC-UMD, Bear Creek upstream of mine drainage; LWLT, Lykens Water-Level Tunnel; LD, Lykens Drift; BC-DMD, Bear Creek downstream of mine drainage; BCM, Bear Creek at mouth; WC-DBC, Wiconisco Creek downstream of Bear Creek] 
median $\mathrm{pH}$ more than 2 units between sites BC-UMD and BC-DMD (median $\mathrm{pH}$ of 4.6 at BC-UMD compared to 6.8 at BC-DMD; $\mathrm{p}$-value $=<0.0001$ ). However, the $\mathrm{pH}$ of streamwater at BC-DMD was not intermediate between the source-water components. In fact, the $\mathrm{pH}$ at $\mathrm{BC}-\mathrm{DMD}$ was greater than the alkaline mine water discharging from site $\mathrm{LD}$ (median $\mathrm{pH}=6.8$ at site BC-DMD compared to 6.5 at site LD). Further, a median $\mathrm{pH}$ of 7.2 in streamwater at site BCM confirms a trend of increasing $\mathrm{pH}$ downstream of site $\mathrm{LD}$.

The most likely explanation for this trend is exsolution of carbon dioxide $\left(\mathrm{CO}_{2}\right)$ and $\mathrm{H}_{2} \mathrm{~S}$ from water discharging at site $\mathrm{LD}$ and associated seeps. Aeration of mine drainage can result in rapid saturation with $\mathrm{O}_{2}$, causing the simultaneous production of hydroxyl ions, $\left(\mathrm{OH}^{-}\right)$and consumption of hydrogen ions (Cravotta and Kirby, 2004a) through the following reactions that represent exsolution of $\mathrm{CO}_{2}$ (eqns. 9 and 10) and $\mathrm{H}_{2} \mathrm{~S}$ (eqn. 11) (Stumm and Morgan, 1996):

$$
\begin{gathered}
\mathrm{HCO}_{3}{ }^{-}=\mathrm{CO}_{2}(\mathrm{~g})+\mathrm{OH}^{-} \\
\mathrm{H}_{2} \mathrm{CO}_{3}{ }^{*}=\mathrm{CO}_{2}(\mathrm{~g})+\mathrm{H}_{2} \mathrm{O} \\
\mathrm{HS}^{-}+\mathrm{H}^{+}=\mathrm{H}_{2} \mathrm{~S}(\mathrm{aq}) \rightarrow \mathrm{H}_{2} \mathrm{~S}(\mathrm{~g})
\end{gathered}
$$

[where $\mathrm{H}_{2} \mathrm{CO}_{3}{ }^{*}=$ dissolved carbon dioxide $\left(\mathrm{CO}_{2}(\mathrm{aq})\right)+$ carbonic acid $\left.\left(\mathrm{H}_{2} \mathrm{CO}_{3}\right)\right]$. These reactions occur more quickly than acid producing hydrolysis (eqn. 4 ) reactions and therefore commonly cause $\mathrm{pH}$ of mine drainage to initially increase (Cravotta and Kirby, 2004a). With time, hydrolysis of dissolved metals may produce enough acidity to lower $\mathrm{pH}$. This was not observed in Bear Creek; pH increased between sites BC-DMD and BCM despite acidity production from hydrolysis of dissolved iron.

Several processes counter acidity production and may explain the apparent contradiction. First, acidity due to $\mathrm{H}_{2} \mathrm{CO}_{3}$ * declines and $\mathrm{pH}$ increases during $\mathrm{CO}_{2}$ exsolution (eqn. 10). Secondly, $\mathrm{H}^{+}$produced by hydrolysis of iron can be consumed during reaction with bisulfide ion $\left(\mathrm{HS}^{-}\right)$in the formation of hydrogen sulfide gas $\left(\mathrm{H}_{2} \mathrm{~S}(\mathrm{~g})\right)$ (eqn. 11). Lastly, high concentration of ANC from site LD (median ANC concentration = $123 \mathrm{mg} / \mathrm{L}$ as $\mathrm{CaCO}_{3}$ ) and possibly from the sewage treatment plant upstream of BCM buffers acidity and may increase $\mathrm{pH}$.

\section{Iron}

Iron is the principal metal pollutant in Bear Creek (Stoe, 1998; Sanders and Thomas, Inc., 1973; Hedin Environmental, 2001; Susquehanna River Basin Commission, 2001). Pyrite oxidation results in production of $\mathrm{Fe}^{2+}$ and $\mathrm{Fe}^{3+}$ ions (eqns. 2 and 3). The valence of dissolved iron in water depends on $\mathrm{pH}$ and Eh. Under the near-neutral condition of water in mineaffected reaches of Bear Creek, the dominant dissolved species was expected to be $\mathrm{Fe}^{2+}$ (Stumm and Morgan, 1996). Hydrolysis of $\mathrm{Fe}^{3+}$ forms relatively insoluble $\mathrm{Fe}(\mathrm{OH})_{3}$ (eqn. 4). This precipitate is orange in color and is ubiquitous in Bear Creek downstream of site BC-UMD. It coats the channel substrate rendering the lower reach of Bear Creek unsuitable for aquatic life (Stoe, 1998).

Site BC-UMD, which has a median total iron concentration of $550 \mu \mathrm{g} / \mathrm{L}$, is useful for evaluation of the collective effect of iron originating from LWLT, LD, and seeps on downstream sites. The differing hydrologic behavior of sites LWLT and LD influences the concentration and phase of iron in each discharge. The short residence time of water draining at site LWLT relative to site LD results in less iron production and oxygen consumption by pyrite oxidation (eqn. 1) and precludes ANC production via sulfate reduction (eqn. 7) because anoxia is not achieved. As a result, the relatively acidic discharge from LWLT has a median total iron concentration that is approximately half that of site LD (10,000 compared to $19,000 \mu \mathrm{g} / \mathrm{L})$.

The phase of iron also differs between sites LWLT and LD. The difference between median total and dissolved iron fractions $(4,830 \mu \mathrm{g} / \mathrm{L}$, fig. 17$)$ in water originating from LWLT indicates that much of the iron at this site had hydrolyzed (eqn. 4) and was suspended. In contrast, nearly all iron originating from LD was in solution (median dissolved iron = $18,300 \mu \mathrm{g} / \mathrm{L}$, median total iron $=19,000 \mu \mathrm{g} / \mathrm{L}$ ). After mixing with mine drainage from sites LWLT, LD, and diffuse zones of seepage, the median total iron concentration at site BC-DMD was $12,600 \mu \mathrm{g} / \mathrm{L}$; a significant increase compared to site BC-UMD (p-value $=<.0001$; table 6). Most iron at BC-DMD was dissolved (median dissolved iron concentration $=$ $9,970 \mu \mathrm{g} / \mathrm{L}$ ), indicating that the traveltime between LD and BC-DMD was too short to allow significant oxidation and hydrolysis of iron to occur. In contrast, most dissolved iron at site BCM had hydrolyzed (eqn. 4) and was suspended (fig. 17).

Because water from LD was nearly anoxic, oxidation of $\mathrm{Fe}^{2+}$ (eqn. 3) and hydrolysis of $\mathrm{Fe}^{3+}$ (eqn. 4) occurred only after oxygen was introduced. Even though deposits of $\mathrm{Fe}(\mathrm{OH})_{3}$ (fig. 5) are evidence that some iron precipitation and settling occurred prior to mixing with Bear Creek, most iron did not undergo hydrolysis by the time it reached site BC-DMD (fig. 17). The conversion of dissolved iron to $\mathrm{Fe}(\mathrm{OH})_{3}$ occurred between sites BC-DMD and BCM, decreasing the median concentration of dissolved iron at site BCM to $1,320 \mu \mathrm{g} / \mathrm{L}$ compared to the total iron concentration of $10,600 \mu \mathrm{g} / \mathrm{L}$ (table 5). The decrease in median total iron between sites BC-DMD and $\operatorname{BCM}(2,000 \mu \mathrm{g} / \mathrm{L})$ indicates that approximately 16 percent of the iron at site BC-DMD was retained in the stream reach between sites BC-DMD and BCM.

On the basis of the low solubility of $\mathrm{Fe}^{3+}$ (Rose and Cravotta, 1998) and the $\mathrm{pH}$ and redox conditions of the mine drainage at site $\mathrm{LD}$, the stable form of iron was expected to be $\mathrm{Fe}^{2+}$ (Stumm and Morgan, 1996). However, ferrous iron was only a fraction of the dissolved concentration (median $\mathrm{Fe}^{2+}=$ $3,900 \mu \mathrm{g} / \mathrm{L}$, median dissolved $=18,300 \mu \mathrm{g} / \mathrm{L}$ ). The near-neutral $\mathrm{pH}$ (median $\mathrm{pH}=6.5$ ) and low oxidation potential (median dissolved oxygen concentration $=0.5 \mathrm{mg} / \mathrm{L} ;$ median $\mathrm{Eh}=154 \mathrm{mV}$ ) indicated this discharge was near the stability boundary between $\mathrm{Fe}^{2+}$ and $\mathrm{Fe}(\mathrm{OH})_{3}$ (Rose and Cravotta, 1998). Consequently, there may have been dissolved $\mathrm{Fe}^{3+}$ in solution that was rapidly undergoing hydrolysis to $\mathrm{Fe}(\mathrm{OH})_{3}$ (eqn. 4). A sec- 


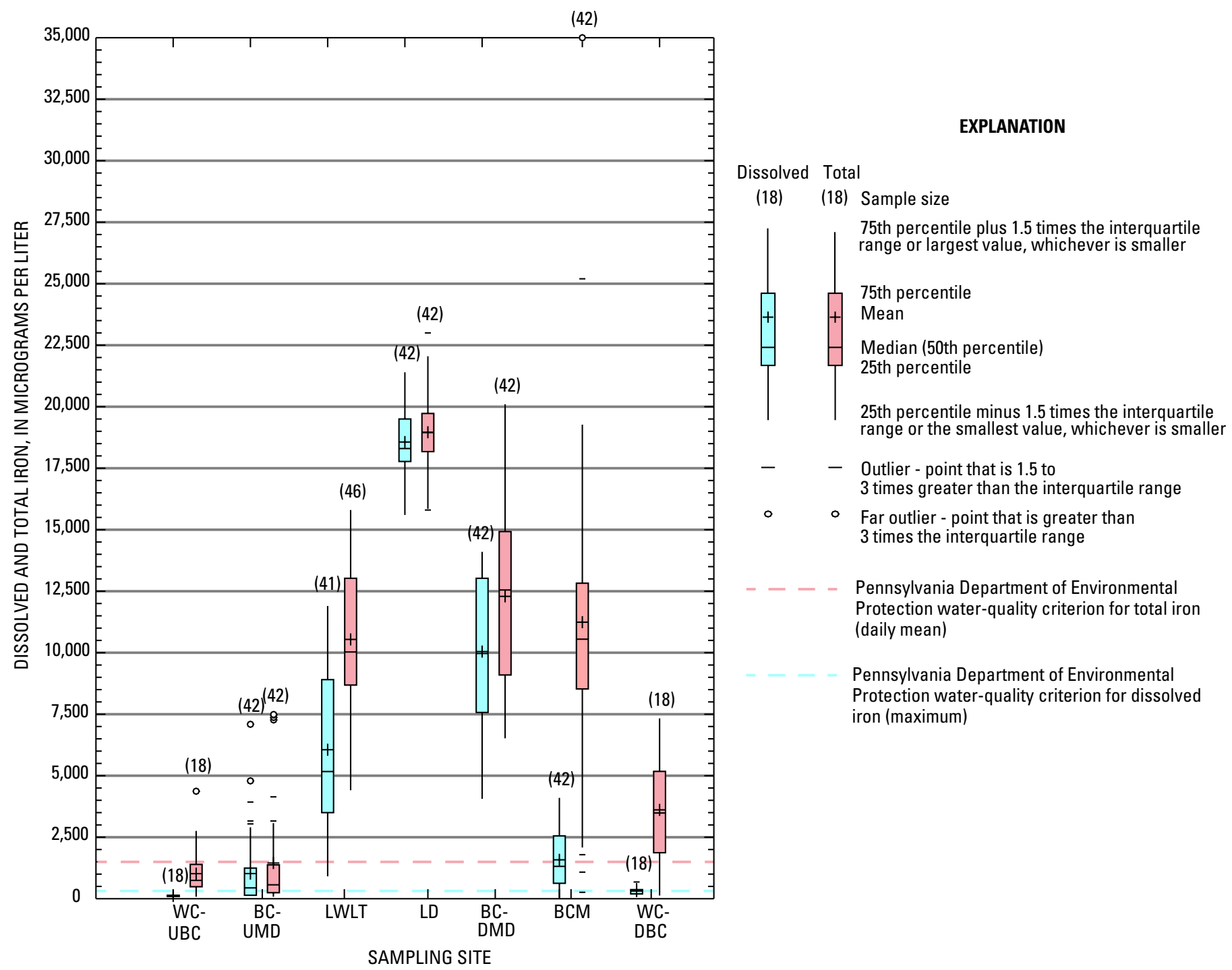

Figure 17. Ranges of dissolved and total iron measured at seven sites in the Bear Creek study area, Dauphin County, Pennsylvania, from March 1999 to December 2002. One value of dissolved iron concentration censored at $<20 \mu \mathrm{g} / \mathrm{L}$ and two values of total iron concentration censored at $<300 \mu \mathrm{g} / \mathrm{L}$ were omitted from the BC-UMD plot.

[WC-UBC, Wiconisco Creek upstream of Bear Creek; BC-UMD, Bear Creek upstream of mine drainage; LWLT, Lykens Water-Level Tunnel; LD, Lykens Drift; BC-DMD, Bear Creek downstream of mine drainage; BCM, Bear Creek at mouth; WC-DBC, Wiconisco Creek downstream of Bear Creek] 
ond possibility for low $\mathrm{Fe}^{2+}$ concentration compared to dissolved iron is that some aeration of the samples could have occurred between collection and analysis. This would cause oxidation of $\mathrm{Fe}^{2+}$ to $\mathrm{Fe}^{3+}$, resulting in measured concentrations of $\mathrm{Fe}^{2+}$ that were less than actual in-situ concentrations.

The relation of total and dissolved iron with flow differs at sites LWLT, LD, BC-DMD, and BCM (fig. 18). Concentrations decreased as flow increased at site LWLT with little change in the ratio of dissolved to total iron (fig. 18). The decrease in concentration with respect to flow was consistent with that of specific conductance (fig. 12) and was the result of dilution from poorly buffered runoff entering between the source and the sampling location or precipitation infiltrating into the local underground mine water that drains to site LWLT. The mine drainage at site LD showed no correlation with flow either in concentration or in the ratio of dissolved to total iron (fig. 18) indicating a poor connection with surface runoff. Increased flow did not seem to alter the proportion of dissolved to total iron at site BC-UMD (fig. 18).

Total iron concentration was inversely correlated with flow at sites BC-DMD and BCM. This correlation results from an increase in the proportion of relatively dilute water originating in the headwaters at high flow. At site BCM, dissolved iron increased slightly as flow increased. The process causing dissolved iron to increase at $\mathrm{BCM}$ during high flow is not clear. Although the $\mathrm{pH}$ of water at site $\mathrm{BCM}$ generally declined with increased flow (fig. 16), it remained near-neutral (minimum $\mathrm{pH}$ $=6.1$; table 5) making the dissolution of relatively insoluble $\mathrm{Fe}(\mathrm{OH})_{3}$ unlikely over the range of measured $\mathrm{pH}$ values. Nonetheless, there are processes facilitated by decreases in $\mathrm{pH}$ and (or) redox potential of streambed sediments or the water column that may increase the concentrations of dissolved metals (Cravotta and Bilger, 2001).

\section{Manganese}

Manganese is a common metal in manganosiderite $\left[(\mathrm{Fe}, \mathrm{Mn}) \mathrm{CO}_{3}\right]($ Cravotta and others, 1994) and various other minerals associated with iron compounds (Williams and others, 1995). Little research exists on its effects on aquatic life; however, it is undesirable in water supplies because of discoloration effects at concentrations as low as $50 \mu \mathrm{g} / \mathrm{L}$ (Hem, 1985, p. 85). Although manganese was lower in concentration than iron, it was elevated in mine water discharging from LWLT and LD (fig. 19), causing manganese concentrations to commonly exceed the water-quality criterion (Pennsylvania Department of Environmental Protection, 1998) and TMDL (Susquehanna River Basin Commission, 2001) at sites BC-DMD and BCM. The oxidation of manganese and formation of solid manganese oxides occurs at pH 8.5 or greater (Walton-Day, 1999). As a result, manganese was transported conservatively in its dissolved state $\left(\mathrm{Mn}^{2+}\right)$ at all sites (fig. 19) over the entire range of hydrologic conditions (fig. 20).

Mine drainage from sites LWLT, LD, and diffuse seeps increased the median total manganese concentration between sites BC-UMD and BC-DMD by nearly 500 percent (table 5 ). The largest contributor of manganese was the LD discharge, which had concentrations that ranged from 1,910 to $2,490 \mu \mathrm{g} / \mathrm{L}$ and had a median total manganese concentration of $2,170 \mu \mathrm{g} / \mathrm{L}$ (table 5). Little change occurred in manganese concentration between sites BC-DMD and BCM (fig. 19). Bear Creek significantly increased the median total manganese concentration in Wiconisco Creek ( $\mathrm{p}$-value $=0.0003$; table 6). The manganese concentration at site WC-DBC was about 100 percent greater than the concentration at site WC-UBC (640 compared to $320 \mu \mathrm{g} / \mathrm{L}$; table 5). The relation between manganese and flow (fig. 20) was similar to that previously described between iron and flow.

\section{Aluminum}

The chemistry of aluminum in water is complex because it can be present in various organic or inorganic complexes that are $\mathrm{pH}$-dependent. Aluminum is least soluble between $\mathrm{pH} 5.7$ to 6.2 and tends to be in solution outside this range (Brown and Sadler, 1989). Elevated concentrations of aluminum can occur in streams receiving abandoned mine drainage or acid precipitation (Baker and Schofield, 1982) or in streams where leaching from mineral soil occurs (Brady, 1990). The aluminum concentration was frequently at or near the detection limit of $<200 \mu \mathrm{g} / \mathrm{L}$ at all sites (table 5).

Despite overall low concentrations, aluminum is more toxic than iron or manganese and may impair aquatic life at concentrations below $200 \mu \mathrm{g} / \mathrm{L}$ (Baker and Schofield, 1982). Further, aluminum concentrations greater than $500 \mu \mathrm{g} / \mathrm{L}$ will generally kill all fish and many macroinvertebrates (Earle and Callaghan, 1998). Toxicity to aquatic life is not only a function of concentration but also is related to $\mathrm{pH}$. The most toxic effects on fish occur between pH 5.2 and 5.4 (Baker and Schofield, 1982). Consequently, ANC provided by mine drainage to Bear Creek may act to mitigate the effects of aluminum by buffering upstream inputs and increasing the $\mathrm{pH}$ of creek water to nearneutral.

Because of a large proportion of aluminum values below the detection limit, interpretation of its effects on the chemistry of Bear Creek is limited. Nonetheless, the quality-control concentrations of total aluminum reported for each site by USGS NWQL in July 2002 were useful to help interpret the total aluminum concentration dataset from the PaDEP laboratory. The NWQL reporting limit for total aluminum concentrations was $30 \mu \mathrm{g} / \mathrm{L}$ compared to multiple detection limits of 200 and $500 \mu \mathrm{g} / \mathrm{L}$ reported by PaDEP. Aluminum concentrations in quality-assurance samples analyzed by NWQL are shown in table 3 but are not included in the summary statistics of table 5 .

Aluminum occasionally was detected in the acidic waters (median $\mathrm{pH}=4.6$ ) of site $\mathrm{BC}-\mathrm{UMD}$ at concentrations greater than or equal to $200 \mu \mathrm{g} / \mathrm{L}$ (table 5 ). The maximum concentration was $600 \mu \mathrm{g} / \mathrm{L}$. Because mine drainage was not a major component of flow at BC-UMD, the source may be aluminum leached from soil as a result of acid precipitation. 
Figure 18. Relation of dissolved and total iron to flow at seven sites in the Bear Creek study area, Dauphin County Pennsylvania. Data were collected from March 1999 to December 2002. One value of dissolved iron concentration censored at $<20 \mu \mathrm{g} / \mathrm{L}$ and two values of total iron censored at $<300 \mu \mathrm{g} / \mathrm{L}$ were omitted from the BC-UMD plot.

[WC-UBC, Wiconisco Creek upstream of Bear Creek; BC-UMD, Bear Creek upstream of mine drainage; LWLT, Lykens Water-Level Tunnel; LD, Lykens Drift; BC-DMD, Bear Creek downstream of mine drainage; BCM, Bear Creek at mouth; WC-DBC, Wiconisco Creek downstream of Bear Creek] 

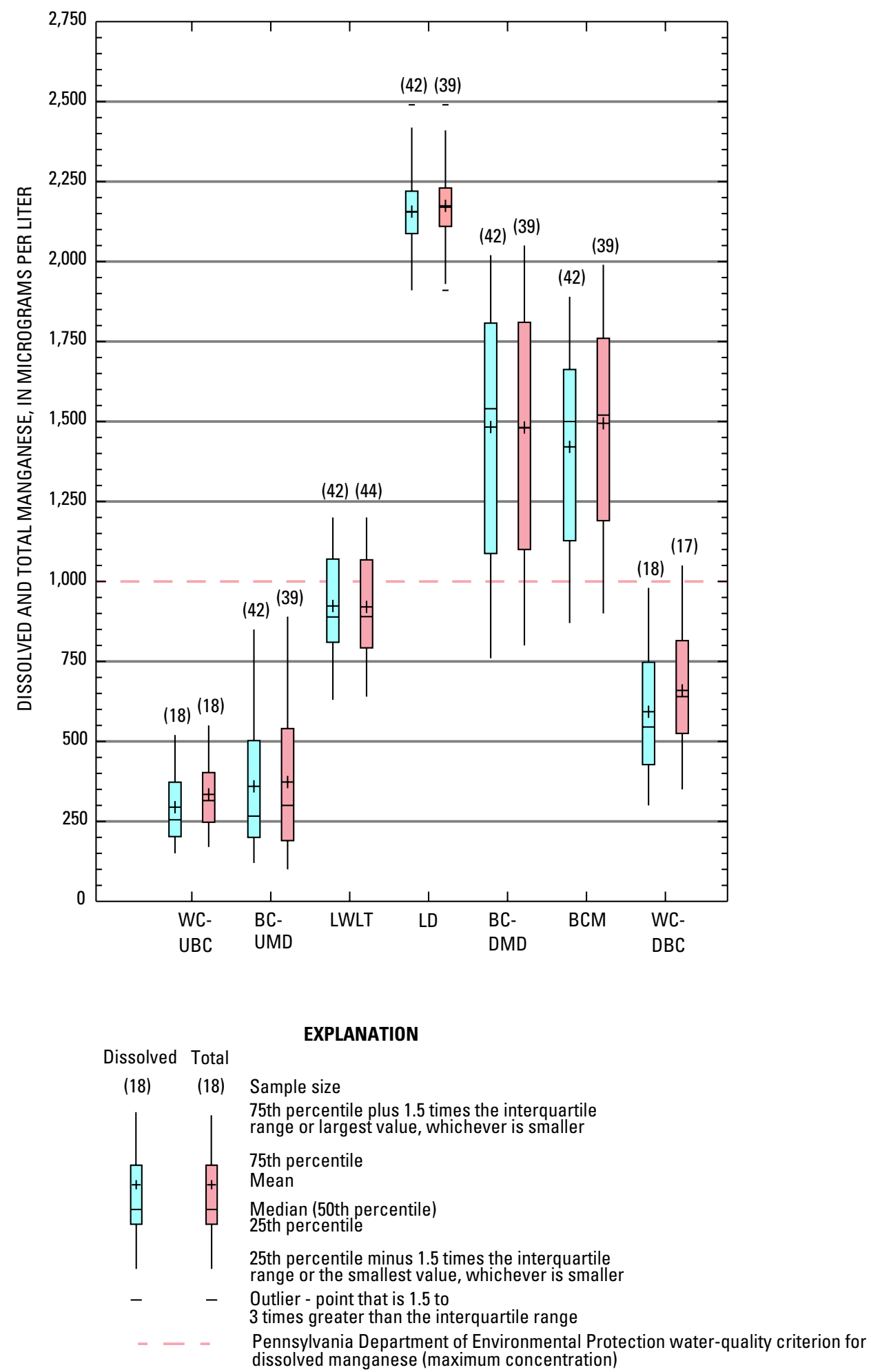

Figure 19. Ranges of dissolved and total manganese measured at seven sites in the Bear Creek study area, Dauphin County, Pennsylvania, from March 1999 to December 2002.

[WC-UBC, Wiconisco Creek upstream of Bear Creek; BC-UMD, Bear Creek upstream of mine drainage; LWLT, Lykens Water-Level Tunnel; LD, Lykens Drift; BC-DMD, Bear Creek downstream of mine drainage; BCM, Bear Creek at mouth; WC-DBC, Wiconisco Creek downstream of Bear Creek] 
FLOW, IN CUBIC FEET PER SECOND

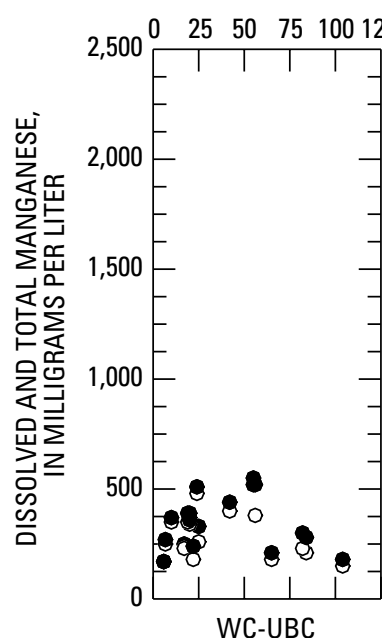

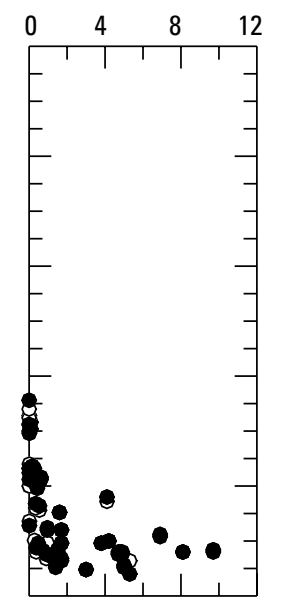

BC-UMD

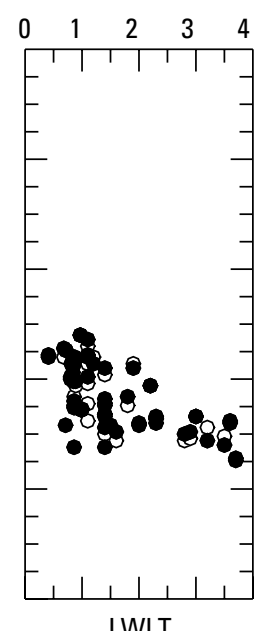

LWLT
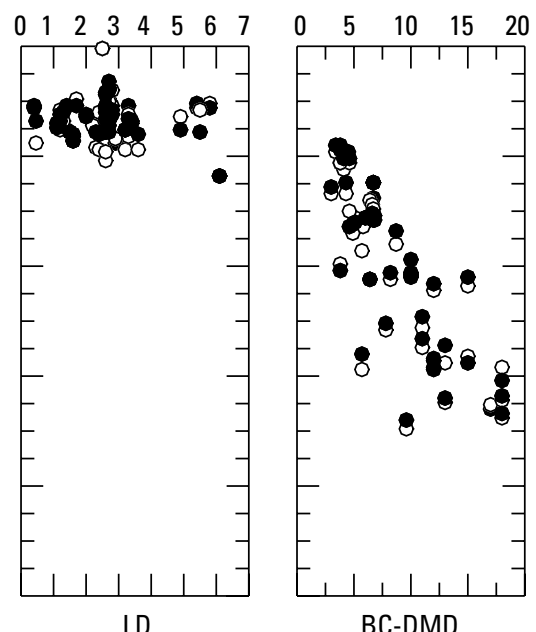

BC-DMD
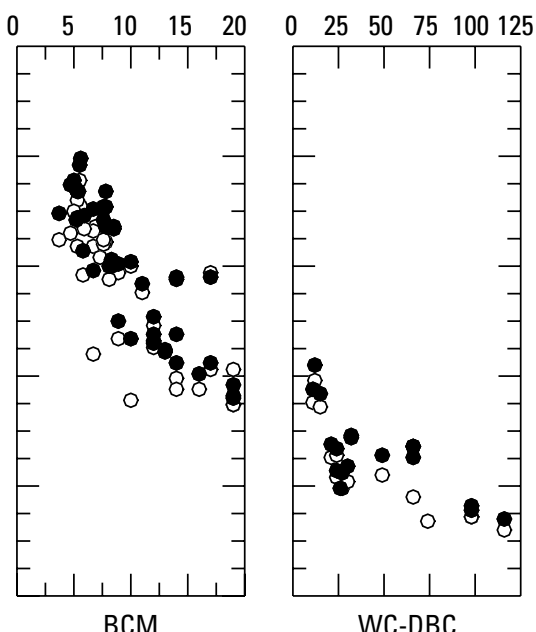

SAMPLING SITE

\section{EXPLANATION}

- DISSOLVED MANGANESE

- tOtAl MANGANESE

Figure 20. Relation of dissolved and total manganese to flow at seven sites in the Bear Creek study area, Dauphin County, Pennsylvania, from March 1999 to December 2002.

[WC-UBC, Wiconisco Creek upstream of Bear Creek; BC-UMD, Bear Creek upstream of mine drainage; LWLT, Lykens Water-Level Tunnel; LD, Lykens Drift; BC-DMD, Bear Creek downstream of mine drainage; BCM, Bear Creek at mouth; WC-DBC, Wiconisco Creek downstream of Bear Creek] 
In the mine discharges, aluminum most commonly exceeded the detection limit at site LWLT where 82 percent of the concentrations were greater than $200 \mu \mathrm{g} / \mathrm{L}$. The range of total aluminum concentrations at site LWLT was $<200 \mu \mathrm{g} / \mathrm{L}$ to $1,000 \mu \mathrm{g} / \mathrm{L}$, and the median was $300 \mu \mathrm{g} / \mathrm{L}$ (table 5). Aluminum concentrations at site LD were less than at site LWLT, where 97 percent of the values were less than $200 \mu \mathrm{g} / \mathrm{L}$. In fact, total aluminum concentrations reported by the NWQL indicate that water discharging from site LD had total aluminum concentrations that were at most about one tenth those of the LWLT discharge ( $<30 \mu \mathrm{g} / \mathrm{L}$ compared to $280 \mu \mathrm{g} / \mathrm{L}$; table 3$)$. Water from $\mathrm{LD}$ diluted the higher concentrations of total aluminum in water from sites BC-UMD and LWLT because it contributes a large proportion of flow to Bear Creek.This dilution effect was evident in water at sites BC-DMD and BCM where total aluminum concentrations commonly were equal to or less than $200 \mu \mathrm{g} / \mathrm{L}$ (table 5). Analyses by the NWQL indicate that the concentration of total aluminum in water at sites BC-DMD and $\mathrm{BCM}$ was $40 \mu \mathrm{g} / \mathrm{L}$ (table 3 ).

Mixing of Bear Creek with Wiconisco Creek also resulted in an apparent decrease in total aluminum concentration by dilution. The median total aluminum concentration at site WC-UBC was $200 \mu \mathrm{g} / \mathrm{L}$ compared to the median at site WC-DBC of less than $200 \mu \mathrm{g} / \mathrm{L}$ (table 5). Data from the NWQL indicate that total aluminum concentration decreased by $40 \mu \mathrm{g} / \mathrm{L}$ between sites WC-UBC and WC-DBC (table 3 ).

\section{Metal Loading Rates}

Total Maximum Daily Loads (TMDLs) represent numeric endpoints used to evaluate the attainment of water-quality standards that, if attained, are expected to restore Bear Creek to a cold-water fishery (Susquehanna River Basin Commission, 2001). TMDLs for metals have been determined for sites BC-UMD, LWLT, LD, BC-DMD, and BCM (Susquehanna River Basin Commission, 2001). Mean loading rates of dissolved iron and total manganese computed from chemistry and flow data collected during this investigation indicate that established TMDLs are equaled or exceeded at all five sites except for the total manganese TMDL at site LWLT (table 7).

Iron and manganese in water draining from LWLT, LD, and diffuse zones of seepage increased the mean load of these constituents in the downstream reach (fig. 21) of Bear Creek. The largest iron load to site BC-DMD was contributed by drainage from site LD (54 percent), followed by diffuse zones of seepage (30 percent) and drainage from site LWLT (16 percent). Collectively, these mine water inputs increased the mean load of iron in Bear Creek (dissolved plus suspended fractions) by about 100 times, from $5 \mathrm{lb} / \mathrm{d}$ at site BC-UMD to $510 \mathrm{lb} / \mathrm{d}$ at site BC-DMD (fig. 21). The mean load of manganese (dissolved plus suspended fractions) increased by 30 times from $2 \mathrm{lb} / \mathrm{d}$ at site BC-UMD to $60 \mathrm{lb} / \mathrm{d}$ at site BC-DMD (fig. 21). A small amount of water containing iron and manganese entered the stream between BC-DMD and BCM, increasing the load at the mouth to $540 \mathrm{lb} / \mathrm{d}$ of iron and $70 \mathrm{lb} / \mathrm{d}$ of manganese (fig. 21).
Table 7. Computed mean loads of dissolved iron and total manganese compared to Total Maximum Daily Loads at selected sites in the Bear Creek watershed, Dauphin County, Pennsylvania.

[BC-UMD, Bear Creek upstream of mine drainage; LWLT, Lykens Water-Level Tunnel; LD, Lykens Drift; BC-DMD, Bear Creek downstream of mine drainage; $\mathrm{BCM}$, Bear Creek at mouth]

\begin{tabular}{llcc}
\hline Site & Constituent & $\begin{array}{c}\text { Mean load } \\
\text { (pounds per } \\
\text { day) }\end{array}$ & $\begin{array}{c}\text { Total Maximum } \\
\text { Daily Load } \\
\text { (TMDL) }\end{array}$ \\
(pounds per day)
\end{tabular}

${ }^{1}$ TMDL represents the Total Maximum Daily Load that will allow Bear Creek to meet its cold-water fishery designation (Susquehanna River Basin Commission, 2001).

${ }^{2}$ TMDL has not been developed for total iron.

Most of the iron in streamwater immediately below the mine discharges was in solution. As water flowed downstream, a conversion of dissolved iron to $\mathrm{Fe}(\mathrm{OH})_{3}$ occurred (eqn. 4), decreasing the median concentration of dissolved iron at BCM to $1,320 \mu \mathrm{g} / \mathrm{L}$ compared to the total iron concentration of $10,600 \mu \mathrm{g} / \mathrm{L}$. Because of this conversion, dissolved iron made up only 19 percent of the mean total iron load at BCM; 81 percent was from iron suspended in the water column. Because a large proportion of the iron load at BCM was suspended, TMDLs developed for dissolved iron (table 7) were met about 10 percent of the time (4 out of 42 load computations); the minimum load was $1.0 \mathrm{lb} / \mathrm{d}$. Even though the TMDL was occasionally met, there was no net reduction in the total iron load or corresponding benefits to aquatic life.

Despite the range of hydrologic conditions during this investigation (fig. 7), iron and manganese loading during wet periods differed little from dry years. The mean iron loading at BCM in 2000, when annual precipitation totaled 51.2 in., was $550 \mathrm{lb} / \mathrm{d}$, compared to $540 \mathrm{lb} / \mathrm{d}$ during drought conditions in 2001 (2001 annual precipitation was only 33.0 in.). Aboveaverage precipitation and the resulting increase in the water level of the mine pool and flow rate of sites LWLT and LD seemed to have only a minor effect on iron and manganese loading to Bear Creek. 
Numbers represent mean loads of total iron and manganese in pounds per day

\section{Lykens Water-}

Level Tunnel

Bear Creek Upstream

$$
\begin{aligned}
& \mathrm{FE}=80 \\
& \mathrm{MN}=7
\end{aligned}
$$
of Mine Drainage

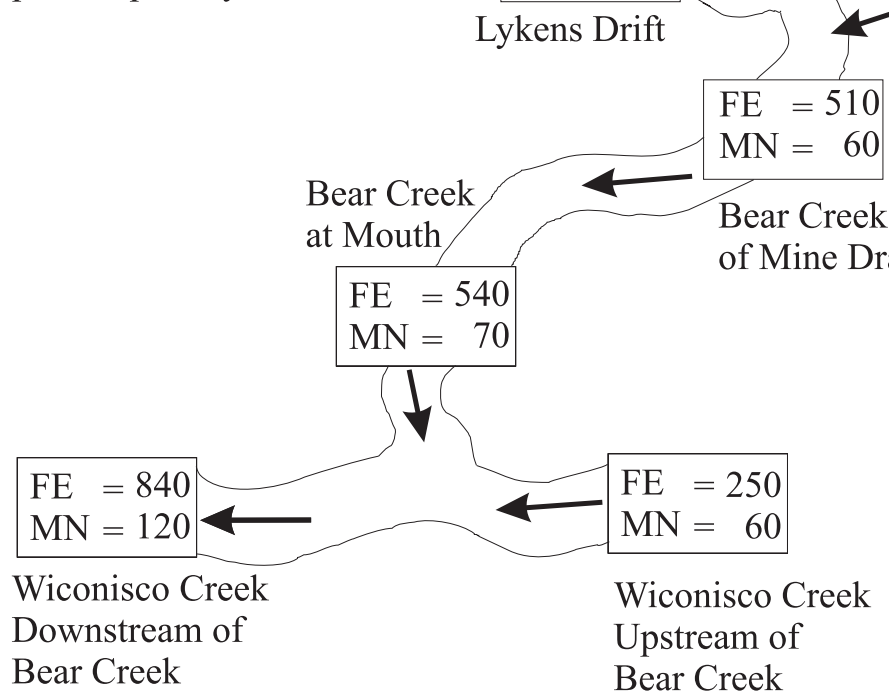

Figure 21. Mean loading rates of total iron (FE) and manganese (MN) in the Bear Creek study area, Dauphin County, Pennsylvania. Locations depicted here represent the relative position of each site where loads were computed (except for diffuse zones of seepage) and are not to scale. Refer to figure 1 for site locations. Unmeasured mine drainage included inputs from mine seeps throughout the watershed. The position of unmeasured mine drainage on this figure is not intended to represent the location of a specific source or sources. Mean loads, except from unmeasured mine drainage, were computed from instantaneous flow and concentration data collected between March 1999 and December 2002. ${ }^{1}$ Mean loads from unmeasured mine drainage were computed from the difference between Bear Creek downstream of mine drainage and the sum of inputs from Bear Creek upstream of mine drainage, Lykens Water-Level Tunnel, and Lykens Drift. 
Passive treatment is under consideration by DCCD (2004) to improve the quality of mine drainage from sites LWLT, LD, and selected diffuse seeps. Preliminary engineering designs by Skelly and Loy, Inc. (2003), for treatment of these discharges indicate that iron removal is the primary objective. Manganese is not a target for treatment because toxicity is not likely at measured concentrations (Earle and Callaghan, 1998) (table 5), and removal by passive treatment is not effective below $\mathrm{pH} 8.5$ (Walton-Day, 1999). The following section describes passivetreatment technologies commonly used to remove iron from mine drainage having chemistry similar to that of water discharging from sites LWLT, LD, and selected diffuse seeps.

\section{Passive-Treatment Technologies for Iron Removal}

Passive treatment refers to treatment that requires minimal additional maintenance after implementation to continue to receive benefits. The science of iron removal by passive treatment - in terms of matching treatment alternatives with influent chemistry-is summarized in figure 22. In general, aerobic wetlands and ponds can treat net alkaline water; Anoxic Limestone Drains (ALD) can treat acidic water with low concentrations of $\mathrm{Al}, \mathrm{Fe}^{3+}$, and dissolved oxygen; Successive AlkalinityProducing Systems (SAPS), anaerobic wetlands, and Oxic

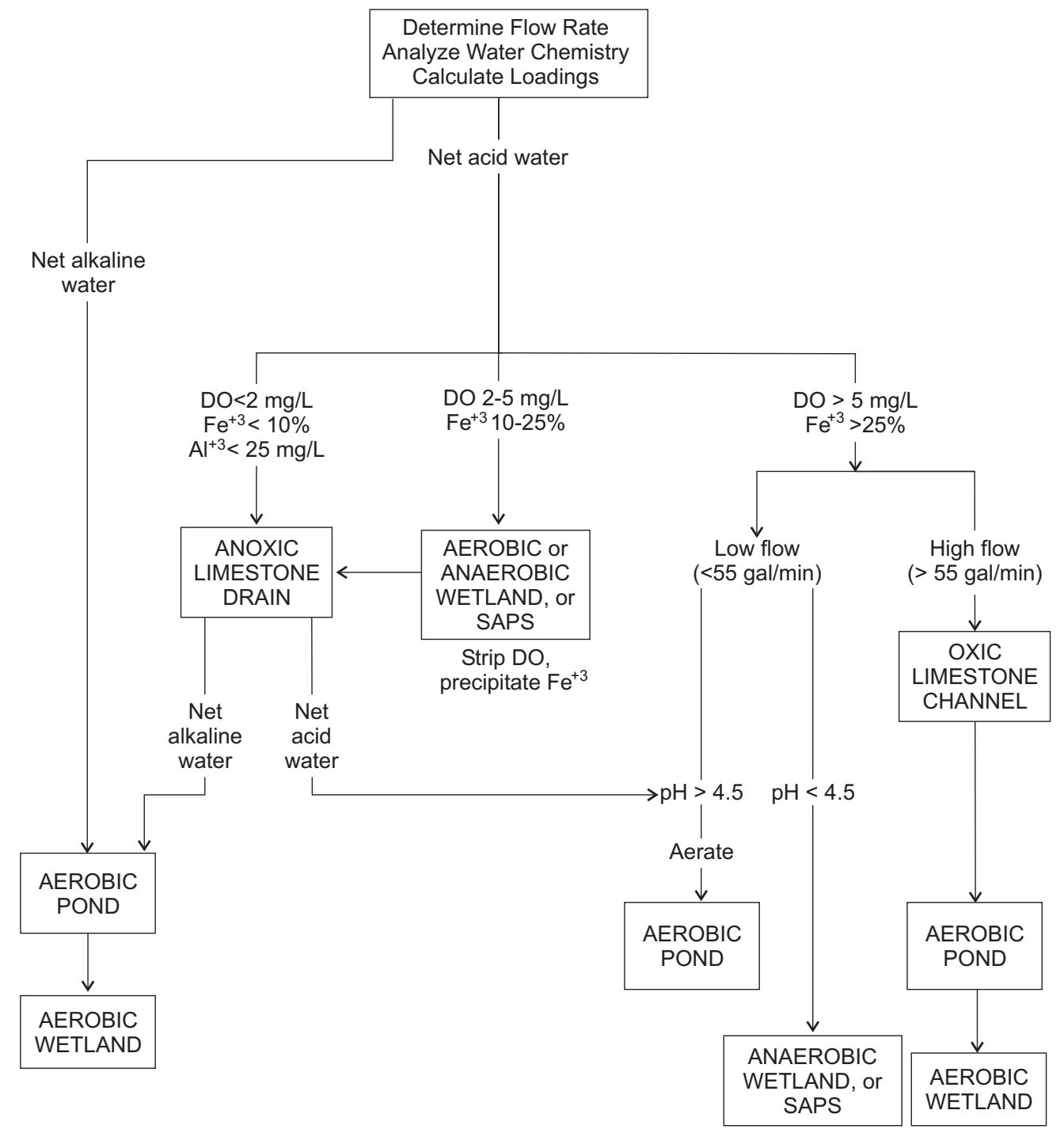

Figure 22. Flow chart of passive-treatment alternatives adapted from Hedin and others (1994) and Skousen and others (2000).

$[<$, less than; $>$, greater than; \%, percent; $\mathrm{mg} / \mathrm{L}$, milligrams per liter; gal/min, gallons per minute; SAPS, Successive Alkalinity-Producing Systems; DO, dissolved oxygen] 
Limestone Channels (OLC) can treat acidic water with high concentrations of $\mathrm{Al}, \mathrm{Fe}^{3+}$, and dissolved oxygen (Skousen and others, 2000). These passive-treatment methods are sometimes used in combination. For example, mine water may initially be routed through relatively deep aerobic ponds that capture most of the suspended iron; residual iron can then be removed by shallow constructed wetlands located downflow (Hedin Environmental, 2001). The mine drainage from sites LWLT and LD has chemical characteristics that can be treated with aerobic ponds and (or) wetlands (fig. 22).

The processes that are most important for removal of iron from mine drainage in aerobic ponds and wetlands are (1) oxidation and hydrolysis (eqns. 3 and 4), and (2) deposition of suspended iron precipitates. Thus, iron removal usually can be facilitated by adding oxygen to oxidize reduced forms of iron, increasing ANC to buffer hydrolysis reactions (eqn. 4), modifying retention time, or some combination of these. Other processes known to remove iron from mine drainage in aerobic ponds and wetlands include ion exchange and adsorption of dissolved constituents onto substrate and complexation of dissolved constituents with organic matter. Plant assimilation of metals also may play a role in iron removal (Walton-Day, 1999).

Addition of ANC to acidic mine drainage entering Bear Creek could be important because iron oxidation, hydrolysis, and subsequent precipitation of iron are influenced by $\mathrm{pH}$. In the absence of excess ANC to buffer the $\mathrm{H}^{+}$produced from hydrolysis (eqn. 4), $\mathrm{pH}$ will decrease, resulting in greater solubility of $\mathrm{Fe}(\mathrm{OH})_{3}$ and attenuation of iron oxidation and hydrolysis. A decrease in $\mathrm{pH}$ of one unit slows the rate of iron oxidation (and the potential for removal) 100-fold (Hedin and others, 1994). Hence, iron is removed most effectively when excess ANC is present (Hedin Environmental, 2001). The addition of ANC in well-oxygenated water like the drainage from site LWLT commonly is accomplished by routing mine drainage through an oxic limestone channel prior to retention in aerobic ponds or wetlands (Hedin and others, 1994; Skousen and others, 2000).

Iron-removal rates per unit area of wetland, based on data from wetlands used to treat mine water draining from bituminous coal mines in western Pennsylvania, have been determined for different mine-drainage chemistries (Hedin and others, 1994). These removal rates commonly are used to size wetlands or aerobic ponds used for passive treatment. Generally, the rate of iron removal increases as concentrations of iron and ANC increase. As the rate of iron removal increases, smaller wetland and aerobic pond size can accomplish equivalent removal. Iron removal rates as high as $20 \mathrm{~g} \mathrm{~m}^{-2} \mathrm{~d}^{-1}\left(178 \mathrm{lb} \mathrm{acre}^{-1} \mathrm{~d}^{-1}\right)$ and as low as $7 \mathrm{~g} \mathrm{~m}^{-2} \mathrm{~d}^{-1}\left(62.5 \mathrm{lb} a c r e^{-1} \mathrm{~d}^{-1}\right)$ have been recommended for sizing aerobic ponds and wetlands to treat net alkaline and net acidic discharges, respectively (Hedin and others, 1994). Because iron concentrations measured in mine water draining to Bear Creek are relatively low compared to those reported by Hedin and others (1994) and water draining from site LWLT is only marginally alkaline, a conservative removal rate of $6 \mathrm{~g} \mathrm{~m}^{-2} \mathrm{~d}^{-1}\left(53.5 \mathrm{lb} \mathrm{acre}^{-1} \mathrm{~d}^{-1}\right)$ was recommended by Hedin Envi- ronmental (1998) to treat the combined discharges from LWLT, $\mathrm{LD}$, and selected diffuse seeps.

Aerobic ponds or wetlands are almost always needed to facilitate iron oxidation, hydrolysis, and deposition. Of 46 mine drainage sources prioritized for treatment by Cravotta and Kirby (2004b) in the Western Middle Field of the Anthracite Coal Region (fig. 1), aerobic ponds or wetlands ranging in size from $<0.1$ to 17.8 acres were components of nearly all treatment scenarios. Despite the need for aerobic ponds and wetlands, land availability frequently constrains their size. As a result, they may not be sized large enough to remove all iron even though mine water can be pretreated to increase the rate of iron removal (fig. 22). In the Bear Creek watershed, options for reshaping land or routing discharges to locations that are more amenable to treatment are limited by steep topography. Thus, the level of iron removal in Bear Creek watershed is dictated by the land area that is available for construction of aerobic ponds and wetlands rather than by the chemical characteristics of drainage from sites LWLT, LD, or diffuse seeps.

On the basis of water-chemistry data collected by USGS and topographic surveys of Bear Creek watershed, Skelly and Loy, Inc. (2003), designed a series of three aerobic ponds (fig. 1) totaling approximately 1.5 acres to treat mine drainage from site LWLT. A separate conceptual design by Skelly and Loy, Inc. (2003), is under consideration (2004) by DCCD to treat water discharging from LD. Both treatment systems were designed to maximize mine-drainage retention time and iron removal within the constraints of available land near each discharge.

\section{Summary and Conclusions}

The Dauphin County Conservation District, through the Pennsylvania Department of Environmental Protection Growing Greener Program, and the U.S. Geological Survey cooperated in an investigation from March 1999 to December 2002 to evaluate the effects of historical coal mining and drainage from abandoned mines on streamflow and water quality in Bear Creek. Hydrologic and chemical data for the evaluation were collected at seven stream sites on Bear Creek, two mine discharges entering Bear Creek, and two stream sites on Wiconisco Creek (one upstream and one downstream of Bear Creek). These data were used to quantify baseline variability in flow characteristics, to demonstrate that discharges located close together can have markedly different chemical characteristics, and to document loadings of iron and manganese, which waterresources managers can use to determine an appropriate passive-treatment technology. The range of flows and chemical compositions documented in mine discharges targeted for treatment in the Bear Creek watershed are characteristic of water from many underground mines in the Southern Anthracite Coal Field. 
Streamwater loss upstream of mine-discharge contributions was commonly 100 percent during periods of minimal precipitation. The streambed was frequently dry during summer months because of permeable and possibly fractured substrate that facilitates streamwater infiltration. Instantaneous flow at Bear Creek upstream of mine drainage (BC-UMD) ranged from 0 to $9.7 \mathrm{ft}^{3} / \mathrm{s}$ and had a mean of $1.9 \mathrm{ft}^{3} / \mathrm{s}$.

When water loss above the mine discharges was 100 percent, base flow in Bear Creek was entirely abandoned mine drainage from the LWLT, LD, and diffuse zones of seepage. Mean streamflow computed from continuous measurements (15-minute intervals) at Bear Creek downstream of mine drainage (BC-DMD) was $8.4 \mathrm{ft}^{3} / \mathrm{s}$ over the study period. Daily means ranged from 1.2 to $108 \mathrm{ft}^{3} / \mathrm{s}$. Storm events influenced the short-term response of streamflow but had little effect on mine drainage from LWLT and LD because of the large storage capacity of the underlying mine pool $\left(980\right.$ million $\mathrm{ft}^{3}$;

7.33 bgal). Unimpacted streamflow above the mine discharges accounted for 16 percent of streamflow under base-flow conditions and 47 percent under stormflow conditions.

The chemistry of Bear Creek upstream of the mine discharges was characterized by aerobic (median dissolved oxygen concentration $=10.0 \mathrm{mg} / \mathrm{L})$, weakly acidic $($ median $\mathrm{pH}=4.6$, net acid neutralizing capacity $(\mathrm{ANC})=-9 \mathrm{mg} / \mathrm{L}$ as $\mathrm{CaCO}_{3}$ ) water with low metals concentration (median total iron $=$ $550 \mu \mathrm{g} / \mathrm{L}$, manganese $=300 \mu \mathrm{g} / \mathrm{L})$. Streamwater downstream of the mine discharges was also aerobic (median dissolved oxygen $=9.4 \mathrm{mg} / \mathrm{L}$ ), but $\mathrm{pH}$ and total iron and manganese concentrations were significantly higher ( $\mathrm{p}$-values $=<0.0001)$. The increase in $\mathrm{pH}$ was chiefly because of the buffering effect of ANC in mine water discharging from site $\mathrm{LD}$ (median net ANC $=123 \mathrm{mg} / \mathrm{L}$ as $\left.\mathrm{CaCO}_{3}\right)$. Exsolution of carbon dioxide $\left(\mathrm{CO}_{2}\right)$ and hydrogen sulfide $\left(\mathrm{H}_{2} \mathrm{~S}\right)$ from water discharging at $\mathrm{LD}$ and associated seeps elevated $\mathrm{pH}$ in the downstream reach of Bear Creek. The increase in iron and manganese downstream of mine discharges was a result of elevated metals concentrations in water discharging from LWLT (median total iron $=$ $10,000 \mu \mathrm{g} / \mathrm{L}$, manganese $=890 \mu \mathrm{g} / \mathrm{L}), \mathrm{LD}$ (median total iron $=$ $19,000 \mu \mathrm{g} / \mathrm{L}$, manganese $=2,170 \mu \mathrm{g} / \mathrm{L}$ ), and diffuse zones of seepage.

Most of the iron in streamwater immediately below the mine discharges was in solution (median dissolved iron concentration $=9,970 \mu \mathrm{g} / \mathrm{L}$ ), indicating that the traveltime between LD and BC-DMD was too short to allow significant oxidation and hydrolysis of iron to occur. As water flowed downstream, oxidation and hydrolysis reactions converted dissolved iron to $\mathrm{Fe}(\mathrm{OH})_{3}$, decreasing the median concentration of dissolved iron at the mouth to $1,320 \mu \mathrm{g} / \mathrm{L}$, compared to median total iron concentration of $10,600 \mu \mathrm{g} / \mathrm{L}$. Consequently, the load of dissolved iron at the mouth of Bear Creek made up only about 19 percent of the total iron load. The remaining 81 percent of iron load was from precipitated iron particles suspended in the water column.

The distinction between dissolved and suspended iron load is important because the Total Maximum Daily Load (TMDL) for iron in Bear Creek has only been developed for dissolved species. On the basis of instantaneous concentration and flow data, mean total iron and manganese loads at the mouth of Bear Creek were 540 and $70 \mathrm{lb} / \mathrm{d}$, respectively. Because the portion of the total iron load attributable to dissolved iron varies significantly at the mouth, the TMDL for dissolved iron at the mouth was met approximately 10 percent of the time (4 out of 42 observations). These instances of TMDL attainment were not indicative of improvement in water quality or benefits to aquatic life. To properly interpret any improvement achieved through attainment of TMDLs developed for dissolved constituents, data for the corresponding suspended fraction are essential.

\section{Acknowledgments}

John Orr, Andrew McAllister, and Jeremy Trexel of DCCD, and Charles McGarrell of PaDEP (formerly of DCCD) were instrumental in project support, coordinating project activities, and field work. Daniel Koury of PaDEP served as liaison with the PaDEP laboratory, which provided most of the waterchemistry analyses. David Saad of USGS provided valuable guidance and technical assistance throughout the writing of this report.

\section{References Cited}

Ash, S.H., Eaton, W.L., Hughes, K., Romischer, W.M., and Westfield, J., 1949, Water pools in Pennsylvania anthracite mines: U.S. Department of the Interior, Bureau of Mines Technical Paper 727, 78 p.

Ash, S.H., and Kynor, H.D., 1953, Barrier pillars in the Southern Anthracite Field, anthracite region of Pennsylvania: U.S. Department of the Interior, Bureau of Mines Bulletin 526, $44 \mathrm{p}$.

Baker, J.P., and Schofield, C.L., 1982, Aluminum toxicity to fish in acidic waters: Water, Air, and Soil Pollution, v. 18, p. 289-309.

Brady, N.C., 1990, The nature and property of soils: New York, MacMillan Publishing Company, 621 p.

Brown, D.J.A., and Sadler, K., 1989, Fish survival in acidic waters, in Morris, R., and others, eds., Acid toxicity and aquatic animals: Society for Experimental Biology Seminar Series, Cambridge, Mass., Cambridge University Press, p. 31-44.

Clesceri, L.S., Greenberg, A.E., and Eaton, A.D., 1998, Standard methods for the examination of water and wastewater (20th ed.): Washington, D.C., American Public Health Association, p. 2-24-2-29.

Cravotta, C.A., III, 1991, Geochemical evolution of acidic ground water at a reclaimed surface coal mine in western Pennsylvania, in Proceedings of the 1991 National Meeting of the American Society of Surface Mining and Reclamation, May 14-17, 1991, Durango, Colo.: Princeton, W. Va., American Society of Surface Mining and Reclamation, p. 4368. 
Cravotta, C.A., III, and Bilger, M.D., 2001, Water-quality trends for a stream draining the Southern Anthracite Field, Pennsylvania: Geochemistry-Exploration, environment, analysis, v. 1, p. 33-50.

Cravotta, C.A., III, Brady, K.B.C., Gustafson-Minnich, L.C., and DiMatteo, M.R., 1994, Geochemical and geohydrological characteristics of bedrock and spoil from two methods of mining at a reclaimed surface coal mine, Clarion County, $\mathrm{Pa}$., USA: U.S. Department of the Interior, Bureau of Mines Special Publication SP-06B-94, p. 242-249.

Cravotta, C.A., III, and Kirby, C.S., 2004a, Acidity and alkalinity in mine drainage-Practical considerations: American Society of Mining and Reclamation, p. 334-365.

Cravotta, C.A., III, and Kirby, C.S., 2004b, Effects of abandoned coal-mine drainage on streamflow and water quality in the Shamokin Creek Basin, Northumberland and Columbia Counties, Pennsylvania, 1999-2001: U.S. Geological Survey Water-Resources Investigations Report 03-4311, $53 \mathrm{p}$.

Drever, J.I., 1988, The geochemistry of natural waters: New Jersey, Prentice Hall, Inc., 437 p.

Durlin, R.R., and Schaffstall, W.P., 2001, Water resources data, Pennsylvania, water year 2000, v. 2-Susquehanna and Potomac River Basins: U.S. Geological Survey WaterData Report PA-00-2, 458 p.

Durlin, R.R., and Schaffstall, W.P., 2002, Water resources data, Pennsylvania, water year 2001, v. 2-Susquehanna and Potomac River Basins: U.S. Geological Survey WaterData Report PA-01-2, 441 p.

Durlin, R.R., and Schaffstall, W.P., 2003, Water resources data, Pennsylvania, water year 2002, v. 2-Susquehanna and Potomac River Basins: U.S. Geological Survey Water-Data Report PA-02-2, 536 p.

Earle, J., and Callaghan, T., 1998, Impacts of mine drainage on aquatic life, water uses, and man-made structures in Brady, K.B.C., and others, eds., Coal mine drainage prediction and pollution prevention in Pennsylvania: Harrisburg, Pa., Pennsylvania Department of Environmental Protection, p. 4-1 through 4-10.

Fishman, M.J., 1993, Methods of analysis by the U.S. Geological Survey National Water-Quality Laboratory-Determination of inorganic and organic constituents in water and fluvial sediments: U.S. Geological Survey Open-File Report 93$125,217 \mathrm{p}$.

Fishman, M.J., and Friedman, L.C., eds., 1989, Methods for determination of inorganic substances in water and fluvial sediments: U.S. Geological Survey Techniques of WaterResources Investigations, book 5, chap. A1, 545 p.

Garbarino, J.R., and Struzeski, T.M., 1998, Methods of analysis by the U.S. Geological Survey National Water Quality Laboratory-Determination of elements in whole-water digests using inductively coupled plasma-optical emission spectrometry and inductively coupled plasma-mass spectrometry: U.S. Geological Survey Open-File Report 98-165, $101 \mathrm{p}$.
Greenberg, A.E., Connors, J.J., Jenkins, David, and Franson, M.A.A., eds., 1981, Standard methods for the examination of water and wastewater (15th ed.): Washington, D.C., American Public Health Association, 1,134 p.

Growitz, D.J., Reed, L.A., and Beard, M.M., 1985, Reconnaissance of mine drainage in the coal fields of eastern Pennsylvania: U.S. Geological Survey Water-Resources Investigations Report 83-4274, 53 p.

HACH Company, 2003, HACH water analysis procedures handbook: accessed February 13, 2004, at http:// www.hach.com

Hedin Environmental, 1998, Remediation of contaminated coal mine discharges in the Wiconisco Creek watershed-An assessment provided for the Susquehanna River Basin Commission: Pittsburgh, Pa., 16 p.

Hedin Environmental, 2001, Remediation of Wiconisco Creek (Dauphin County, Pa.) through remediation of mine drainage in the Bear Creek watershed: Pittsburgh, Pa., 7 p.

Hedin, R.S., Nairn, R.W., and Kleinmann, R.L.P., 1994, Passive-treatment of coal mine drainage: U.S. Bureau of Mines Information Circular IC 9389, 35 p.

Helsel, D.R., and Hirsch, R.M., 2002, Statistical methods in water resources: U.S. Geological Survey Techniques of Water-Resources Investigations, book 4, chap. A3, p. 142147.

Hem, J.D., 1985, Study and interpretation of the chemical characteristics of natural water (3d ed.): U.S. Geological Survey Water-Supply Paper 2254, 263 p.

Kirby, C.S., 2002, Problems in alkalinity and acidity measurements in mine drainage, in Proceedings of the 19th Annual Meeting of American Society of Mining and Reclamation, Lexington, Ky., June 9-13, 2002: American Society of Mining and Reclamation, p. 1,068-1,072.

Morrison, J.L., Atkinson, S.D., and Scheetz, B.E., 1990, Delineation of potential manganese sources in the coal and overburdens of western Pennsylvania, in Proceedings of the 1990 Mining and Reclamation Conference and Exhibition: Charleston, W.Va., April 23-26, 1990, v. 1, p. 249-256.

Northeast Regional Climate Center, 2003, CLIMOD: Ithaca, N.Y., Cornell University-NRCC, accessed March 10, 2003, at http://climod.nrcc.cornell.edu.

Pennsylvania Department of Conservation and Natural Resources, 2000, Distribution of Pennsylvania coals: Harrisburg, Pa., Bureau of Topographic and Geologic Survey, map 11, scale 1:2,000,000.

Pennsylvania Department of Environmental Protection, 1996, Pennsylvania Bulletin: Harrisburg, Pa., v. 26, no. 46, p. 5,648 .

Pennsylvania Department of Environmental Protection, 1998, Pennsylvania code: Harrisburg, Pa., Title 25, §§ 93.1-93.9, $213 \mathrm{p}$.

Rantz, S.E., and others, 1982a, Measurement and computation of streamflow-1. Measurement of stage and discharge: U.S. Geological Survey Water-Supply Paper 2175, v. 1, $284 \mathrm{p}$. 
Rantz, S.E., and others, 1982b, Measurement and computation of streamflow-2. Computation of discharge: U.S. Geological Survey Water-Supply Paper 2175, v. 2, 631 p.

Rose, A.W., and Cravotta, C.A., III, 1998, Geochemistry of coal mine drainage in Brady, K.B.C., and others, eds., Coal mine drainage prediction and pollution prevention in Pennsylvania: Harrisburg, Pa., Pennsylvania Department of Environmental Protection, p. 1-1 through 1-22.

Sanders and Thomas, Inc., 1973, Operation Scarlift-Wiconisco Creek Mine Drainage Pollution Abatement Project: Pottstown, Pa., 79 p. plus appendixes.

Skelly and Loy, Inc., 2003, The remediation of coal mine drainage in the Bear Creek watershed, Wiconisco Township, Dauphin County, Pennsylvania: Harrisburg, Pa., 51 p. plus appendixes.

Skousen, J.G., Sexstone, A., and Ziemkiewicz, P.F., 2000, Acid mine drainage control and treatment, in Barnhisel, R.I., and others, eds., Reclamation of drastically disturbed lands: Madison, Wis., USA Publishers, p. 131-168.

Stoe, T.W., 1998, Water-quality and biological assessment of the Wiconisco Creek watershed: Harrisburg, Pa., Susquehanna River Basin Commission Publication 193, 107 p.

Stumm, W., and Morgan, J.J., 1996, Aquatic chemistry, chemical equilibria and rates in natural waters ( $3 \mathrm{~d}$ ed.): New York, John Wiley and Sons, Inc., 1,022 p.

Susquehanna River Basin Commission, 2001, Bear Creek watershed TMDL: Harrisburg, Pa., 44 p.

U.S. Environmental Protection Agency, 1994, Methods for the determination of metals in environmental samples, supplement I: $\quad$ EPA/600/R-94/111, p. 200.7-1 to 200.7-58.

U.S. Environmental Protection Agency National Exposure Research Laboratory, 1993, Methods for the determination of inorganic substances in environmental samples: EPA/600/ R-93/100, p. 375.1 to 375.2-13.

U.S. Geological Survey, 2005, NWIS Web Data for Pennsylvania: U.S. Geological Survey data available on the Web, accessed February 16, 2005, at http://waterdata.usgs.gov/pa/nwis?

Walton-Day, Katherine, 1999, Geochemistry of the processes that attenuate acid mine drainage in wetlands, in Plumee, G.S., and Logsdon, M.J., eds., The environmental geochemistry of mineral deposits, Part A-Processes, techniques, and health issues: Chelsea, Mich., Society of Economic Geologists, Review in Economic Geology, v. 6A, p. 215-228.

Ward, J.R., and Harr, C.A., eds., 1990, Methods for collection and processing of surface-water and bed material samples for physical and chemical analyses: U.S. Geological Survey Open-File Report 89-584, 61p.

Wilde, F.D., Radtke, D.B., Gibs, Jacob, and Iwatsubo, R.T., 1998, Preparations for water sampling: U.S. Geological Survey Techniques of Water-Resources Investigations, book 9, chap. A6, accessed February 13, 2004, at http://pubs.water.usgs.gov/twri9A6.
Williams, D.R., Ritter, J.R., and Mastrilli, T.M., 1995, Effects of surface mining on the hydrology and biology in the Stony Fork basin, Fayette County, Pennsylvania, 1978-85: U.S. Geological Survey Water-Resources Investigation Report 95-4056, 33 p.

Wood, C.R., 1996, Water-quality of large discharges from mines in the anthracite region of eastern Pennsylvania: U.S. Geological Survey Water-Resources Investigations Report 95-4243, 68 p.

Wood, G.H., Jr., Kehn, T.M., and Eggleston, J.R., 1986, Depositional and structural history of the Pennsylvania Anthracite region, in Lyons, P.C., and C.L. Rice, eds., Paleoenvironmental and tectonic controls in coal-forming basins of the United States: Geological Society of America Special Paper 210, p. 31-47.

Wood, G.H., Jr., and Trexler, J.P., 1968, Geologic maps of Anthracite-bearing rocks in the west-central part of the Southern Anthracite Field, western area: U.S. Geological Survey Miscellaneous Geologic Investigations Map I-529, 4 sheets.

Wood, G.H., Trexler, J.P., Arndt, H.H., Yelenosky, A., and Soren, J., 1956, Subdivision of the Pottsville formation in the Southern Anthracite Field, Pennsylvania: American Association of Petroleum Geologists Bulletin, v. 40, no. 11, p. 2,669-2,688.

Wood, G.H., Jr., Trexler, J.P., and Kehn, T.M., 1969, Geology of the west-central part of the Southern Anthracite Field and adjoining areas, Pennsylvania: U.S. Geological Survey Professional Paper 602, 150 p. 